\title{
DISTÂNCIAS GENÉTICAS ENTRE LINHAGENS E CORRELAÇÕES COM AS PERFORMANCES DE HÍBRIDOS SIMPLES DE MILHO, UTILIZANDO MARCADORES AFLP E SSR
}

\author{
ANTÔNIA MARLENE MAGALHÃES BARBOSA
}

Engenheiro Agrônomo

Orientador: Prof. Dr. ISAÍAS OLÍVIO GERALDI

Tese apresentada à Escola Superior de Agricultura "Luiz de Queiroz", Universidade de São Paulo, para obtenção do título de Doutor em Agronomia, Área de Concentração Genética e Melhoramento de Plantas

PIRACICABA

Estado de São Paulo - Brasil

Junho -2001 


\section{ERRATA}

resumo (p. vii e viii) deve ser substituído pelo resumo apresentado a seguir:

\section{RESUMO}

Dois grupos de linhagens de milho tropical, um derivado da população BR105 e outro da população BR106, foram avaliados com os marcadores AFLP e microssatélites (SSR), para estimar as distâncias genéticas entre as linhagens, visando a alocação destas a grupos heteróticos e as relações entre as distâncias genéticas e as performances de híbridos simples para produção de grãos.

As distâncias genéticas (DG) entre todos os pares de linhagens foram determinadas utilizando o coeficiente de Jaccard (dados de AFLP) e a distância modificada de Rogers (dados de SSR). As análises de agrupamento foram feitas utilizando o método UPGMA (unweighted pair-group method with arithmetical averages). As correlações entre as distâncias genéticas e as performances dos híbridos $F_{1}$ e heteroses para os 148 híbridos simples foram estimadas através do coeficiente de correlação de Pearson. Cinco cruzamentos foram excluidos dessa análise: quatro correspondentes a parcelas perdidas e um correspondente a linhagens irmãs (todos da BR106). Os híbridos simples intra e interpopulacionais foram obtidos segundo um esquema dialélico e avaliados experimentalmente em delineamentos em látice em três ambientes.

As distâncias genéticas foram em média maiores para os cruzamentos interpopulacionais, com os dois marcadores. As análises de agrupamentos com AFLP concordaram em grande parte com as informações das genealogias das linhagens. A linhagem 16, oriunda da população BR106, foi alocada ao grupo da BR105, concordando com os dados de produção de grãos dos híbridos intra e interpopulacionais. Entretanto, o mesmo padrão não ocorreu com o marcador SSR, visto que 3 linhagens da BR106 (linhagens 9, 10 e 16) foram alocadas ao grupo da BR105. Uma possivel explicação para essa discrepância seria o número relativamente pequeno de primers utilizado (68).

Os coeficientes de correlação entre as distâncias genéticas e as performances dos híbridos $F_{1}$ e heteroses foram altos para os cruzamentos intrapopulacionais da BR106 (0,91 e 0,82 para AFLP e SSR, respectivamente), médios para os cruzamentos intrapopulacionais da BR105 (0,52 e 0,52 para AFLP e SSR, respectivamente) e baixos para os cruzamentos interpopulacionais $(0,29$ e 0,16 para AFLP e SSR, respectivamente). A menor correlação observada nos hibridos interpopulacionais foi devida à menor variação para DG.

Os resultados mostraram que os marcadores AFLP são eficientes para alocar linhagens de milho a grupos heteróticos e que as distâncias genéticas obtidas com AFLP podem ser úteis na predição das performances de hibridos simples, reduzindo a quantidade de trabalho e custos relacionadas com a avaliação experimental dos híbridos. Um padrão semelhante foi observado para o marcador SSR. Entretanto, para este são necessárias mais informações, a fim de esclarecer alguns resultados conflitantes sobre os agrupamentos, através do acréscimo do número de primers. 


\section{Dados Internacionais de Catalogação na Publicação (CIP) DIVISÃO DE BIBLIOTECA E DOCUMENTAÇĀO - Campus "Luiz de Queiroz"/USP}

\section{Barbosa, Antônia Marlene Magalhães}

Distâncias genéticas entre linhagens e correlações com as performances de hibridos simples de milho, utilizando marcadores AFLP e SSR / Antônia Marlene Magalhăes Barbosa. - Piracicaba, 2001.

$93 \mathrm{p}$.

Tese (doutorado) - Escola Superior de Agricultura Luiz de Queiroz, 2001. Bibliografia.

1. Heterose 2. Linhagem vegetal 3. Marcador genético 4. Milho hibrido 5. População genética I. Título

$\operatorname{CDD} 633.15$ 


\section{A Paulo, meu companheiro \\ E, principalmente, ao meu filho Vitor \\ Dedico}




\section{AGRADECIMENTOS}

Agradeço a todos que contribuiram para que esse trabalho fosse realizado:

Ao Prof. Dr. Isaias Olívio Geraldi, pela orientação e principalmente pelas sugestões e correções que foram essencias para a elaboração final da tese.

Aos Professores Dr. Claúdio Lopes de Souza Júnior e. Dra. Anete Pereira de Souza, por terem possibilitado a realização desse trabalho, dentro do projeto sobre marcadores moleculares em milho, que está sendo desenvolvido em conjunto pelo Departamento de Genética da ESALQ/USP e o CBEMEG (UNICAMP), financiado pela FAPESP.

Ao CNPq pela bolsa fornecida durante o curso.

Ao Prof. Dr. Antônio Augusto Franco Garcia, pelo auxílio na condução das análises com os dados de marcadores.

Ao Colega Alexandre Siqueira Guedes Coelho pelas sugestões na escolha de programas estatísticos e discussões de trabalhos científicos.

Aos colegas do Departamento de Genética e do Laboratório de Biologia Molecular - CEBMEG, pelos bons momentos de convívio. 


\section{SUMÁRIO}

Página

RESUMO

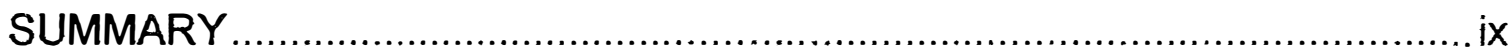

1 INTRODUÇÃO

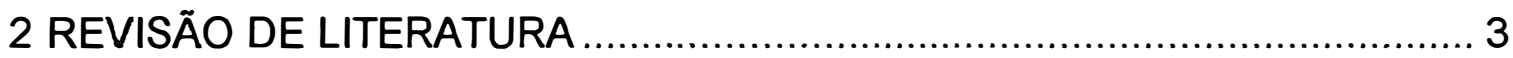

2.1 Distâncias genéticas e heterose........................................................... 3

2.2 Predição das performances de híbridos simples de milho com

marcadores bioquímicos e moleculares ................................................. 5

2.3 Marcador AFLP: princípio e aplicação da técnica .................................... 14

2.4 Marcador microssatélite: princípio e aplicação da técnica .......................... 16

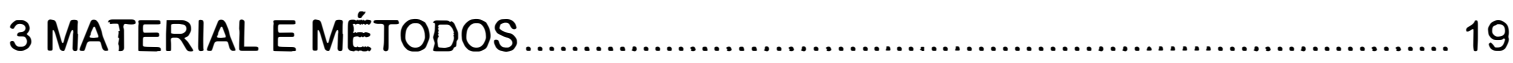

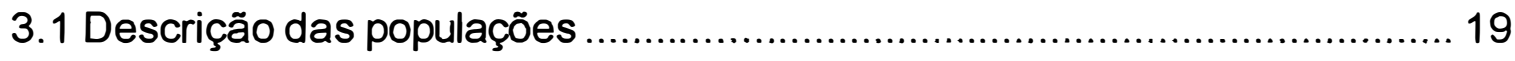

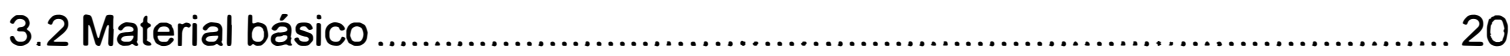

3.3 Avaliação experimental das linhagens em cruzamentos dialélicos ............ 21

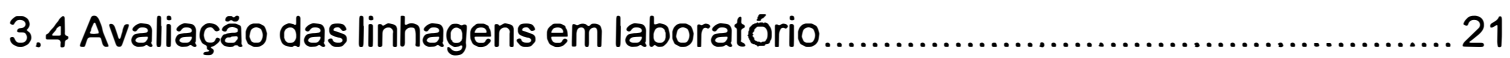

3.4.1 Preparação do material vegetal e extração do DNA ………………........ 21

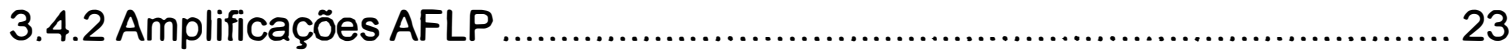

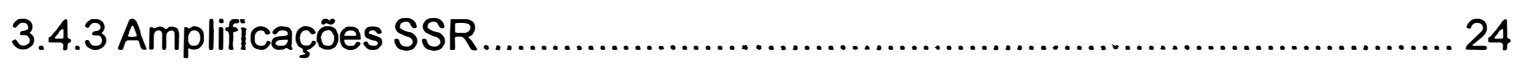

3.5 Análises estatísticas utilizando os dados obtidos com os marcadores ...... 27

3.5.1 Cálculo das distâncias genéticas utilizando o marcador AFLP .............. 27

3.5.2 Cálculo das distâncias genéticas utilizando o marcador SSR ................. 27

3.5.3 Agrupamentos das linhagens e análises de coordenadas principais ...... 28

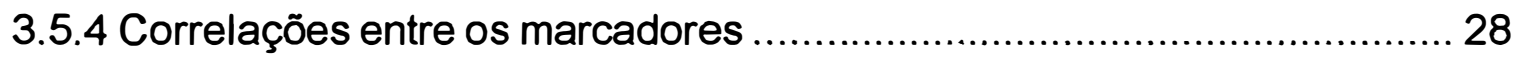

3.5.5 Análise bootstrap dos marcadores AFLP e SSR ................................. 29 
3.6 Correlações entre as distâncias genéticas e as médias de heterose da produção de grãos ..

4 RESULTADOS E DISCUSSÃO

4.1 Otimização do protocolo de amplificação dos locos AFLP ........................ 32

4.2 Otimização do protocolo de amplificação dos locos SSRs......................... 34

4.3 Níveis de polimorfismos obtidos com AFLP e SSR ................................ 34

4.4 Distâncias genéticas obtidas com os dois marcadores .......................... 36

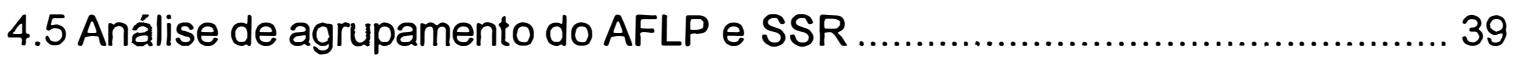

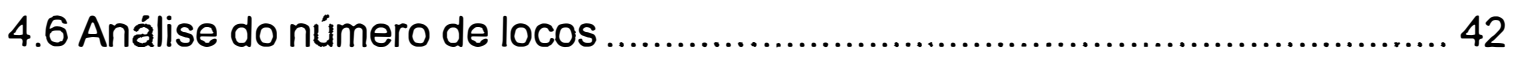

4.7 Performance de híbridos e distâncias genéticas entre as linhagens com os dois marcadores............................................................................... 43

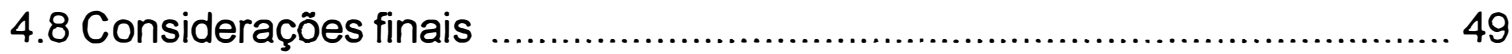

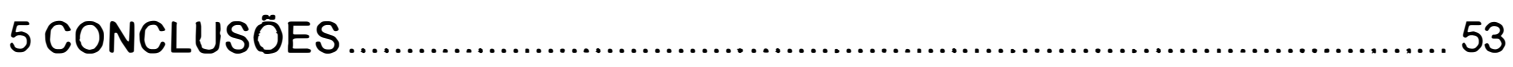

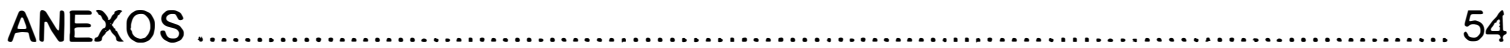

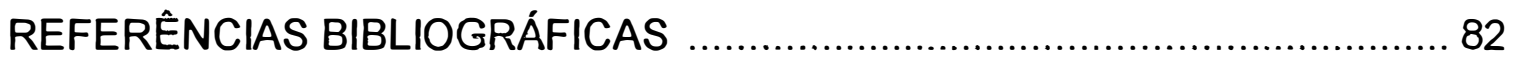




\section{DISTÂNCIAS GENÉTICAS ENTRE LINHAGENS E CORRELAÇÕES COM AS PERFORMANCES DE HIBBRIDOS SIMPLES DE MILHO, UTILIZANDO MARCADORES AFLP E SSR}

Autor: Antônia Marlene Magalhães Barbosa Orientador: Prof. Dr. Isaias Olívio Geraldi

RESUMO

Dois grupos de linhagens de milho tropical, um derivado da população BR105 e outro da população BR106, foram avaliados com os marcadores AFLP, para estimar as distâncias genéticas entre as linhagens, visando a alocação destas a grupos heteróticos e as relações entre as distâncias genéticas e as performances de híbridos simples para produção de grãos.

As distâncias genéticas (DG) entre todos os pares de linhagens foram determinadas utilizando o coeficiente de Jaccard (dados de AFLP). As análises de agrupamento foram feitas utilizando o método UPGMA (unweighted pairgroup method with arithmetical averages). As correlações entre as distâncias genéticas e as performances dos híbridos $F_{1}$ e heteroses para os 148 híbridos simples foram estimadas através do coeficiente de correlação de Pearson. Cinco cruzamentos foram excluídos dessa análise: quatro correspondentes a parcelas perdidas e um correspondente a linhagens irmãs (todos da BR106). Os híbridos simples intra e interpopulacionais foram obtidos segundo um esquema dialélico e avaliados experimentalmente em delineamentos em látice em três ambientes. 
As distâncias genéticas foram em média maiores para os cruzamentos interpopulacionais. As análises de agrupamento com AFLP concordaram em grande parte com as informações das genealogias das linhagens. A linhagem 16 , oriunda da população BR106, foi alocada ao grupo da BR105, concordando com os dados de produção de grãos dos híbridos intra e interpopulacionais.

Os coeficientes de correlação entre as distâncias genéticas e as performances dos híbridos $F_{1}$ e heteroses foram altos para os cruzamentos intrapopulacionais da BR106 (0,91), médios para os cruzamentos intrapopulacionais da BR105 $(0,52)$ e baixos para os cruzamentos interpopulacionais $(0,29)$. A menor correlação observada nos híbridos interpopulacionais foi devida à menor variação para DG.

Os resultados mostraram que o marcador AFLP é eficiente para alocar linhagens de milho a grupos heteróticos e que as distâncias genéticas obtidas com AFLP podem ser úteis na predição das performances de híbridos simples, reduzindo a quantidade de trabalho e custos relacionadas com a avaliação experimental de híbridos. 


\title{
GENETIC DISTANCES OF INBRED LINES AND CORRELATION WITH SINGLE CROSS PERFORMANCE IN MAIZE, USING AFLP AND SSR MOLECULAR MARKERS
}

\author{
Author: Antônia Marlene Magalhães Barbosa \\ Adviser: Prof. Dr. Isaias Olívio Geraldi
}

\section{SUMMARY}

Two set of tropical inbred lines, one derived from BR105 population and other derived from BR106 population, were assayed for AFLP and for microsatellites (SSR), in order to investigate genetic distances among lines and their relationship to heterotic group allocation and single cross yield performance.

Genetic distances for all possible pairs of inbreds were determined using Jaccard's similarity coefficient (AFLP data) and modified Roger's genetic distance (SSR data). Cluster analyses were performed using UPGMA (unweighted pair-group method with arithmetical averages). Pearson correlation coefficients were estimated for genetic distances (GD) with $F_{1}$ grain yield and heterosis for the 148 single crosses derived from intra- and interpopulation crosses. Five crosses were excluded from this analysis: four corresponded to missing plots and one corresponded to sister lines (from BR106). The single crosses and lines were crossed following a diallel scheme at both intra- and interpopulation levels and evaluated in lattice designs across three environments. 
Genetic distances (GD) was on the average greater for interpopulation than intrapopulation crosses for both, AFLP and SSR. Cluster analysis from AFLP was almost in accordance with pedigree information. The inbred line 16, derived from BR106, was assigned to BR105 set. The assignment of inbred 16 to BR105 set is in accordance with single cross yield performance and heterosis from intra- and interpopulation crosses. However, the same pattern was not observed for SSR, where 3 lines from BR106 (9, 10 and 16) were assigned to BR105 set. One possible reason for this result is the low number of primers assayed (68).

Correlation coefficients of genetic distances with $F_{1}$ grain yield and heterosis were high for BR106 $\times$ BR106 crosses (0.91 and 0.82 for AFLP and SSR, respectively), medium for BR $105 \times$ BR 105 crosses (0.52 and 0.52 for AFLP and SSR, respectively) and low for BR $105 \times$ BR 106 crosses (0.29 and 0.16 for AFLP and SSR, respectively). The reason for the lower correlation at interpopulation level was the smaller variation for $\mathrm{GD}$.

General results showed that AFLP molecular marker is efficient in allocating maize lines to heterotic groups and that AFLP-based GD are suitable for predicting the performance of maize single crosses in order to reduce the costs related with experimental evaluation of plots. The same general pattern was observed for SSR molecular marker. However, more information is needed on SSR molecular marker, by increasing the number of primers. 


\section{INTRODUÇÃO}

A magnitude da heterose depende da escolha apropriada dos genitores. $O$ aumento da eficiência do melhoramento para a heterose exige um critério simples e confiável para a seleção de genitores que produzam boas combinações heteróticas sem a necessidade de avaliações experimentais extensivas de cruzamentos no campo, ou que pelo menos simplifique esta etapa. Muitos estudos de performance per se, capacidade de combinação e diversidade genética tem sido utilizados para a seleção de genitores. inicialmente os estudos de diversidade genética e heterose foram realizados através de informações de genealogia, características morfológicas e dados bioquímicos. Com 0 advento dos marcadores moleculares surgiu a possibilidade de avaliar-se no laboratório a divergência genética entre as linhagens, e utilizar esses dados para a identificação daquelas que poderiam gerar híbridos superiores.

Os marcadores moleculares analisam a diversidade genética diretamente ao nível de DNA e, portanto, não sofrem influência ambiental. Além disso, eles apresentam uma série de vantagens em relação aos outros tipos de marcadores morfológicos, bioquímicos (isoenzimas) ou citológicos utilizados inicialmente: são herdados como marcadores mendelianos, livres de efeitos pleiotrópicos, são ilimitados em número e têm distribuição aleatória no genoma. Várias classes de marcadores moleculares foram descritos, tais como, minissatélites, microssatélites, polimorfismo de restrição e amplificação de regiōes aleatórias do genoma. Os mais utilizados em plantas, até o momento, para construção de mapas genéticos, mapeamento de genes de interesse e 
estudos de diversidade genética são os marcadores RFLP (Restriction Fragment Length Polymorphisms) e RAPD (Random Amplified Polymorphic DNA). Marcadores mais recentemente descobertos como os microssatélites (SSRs) e AFLP (Amplified Fragment Length Polymorphism) estão sendo utilizados para a análise de diversidade genética e mapeamento genético.

Os diversos estudos conduzidos para avaliar o potencial de marcadores bioquímicos e moleculares para predição de heterose em híbridos de milho apresentaram resultados contraditórios. Os resultados de estudos com correlação entre diversidades estimadas com marcadores e as performances de híbridos variaram com o tipo de material utilizado nos experimentos e o marcador.

Este trabalho tem por objetivo avaliar a viabilidade de uso de marcadores tipo AFLP e SSR para a avaliação de linhagens tropicais de milho, visando:

(1) estimar as distâncias genéticas entre linhagens e a alocação destas em grupos heteróticos;

(2) avaliar a eficiência desses marcadores na predição das performances de híbridos simples. 


\section{REVISÃO DE LITERATURA}

\subsection{Distâncias genéticas e heterose}

Distâncias genéticas entre populações, indivíduos ou linhagens, estimadas a partir de ancestrais comuns, marcadores bioquímicos ou de DNA, têm sido amplamente utilizadas em análises descritivas de plantas, para a reconstrução da história do melhoramento, descrição dos padrões de diversidade genética, alocação de grupos heteróticos ou outros grupos biológica ou economicamente importantes (Cheres et al., 2000). O reconhecimento e a exploração de padrões heteróticos entre grupos de germoplasma geneticamente divergentes são fundamentais no melhoramento de híbridos (Hallauer et al., 1988). A classificação de germoplasmas elites em grupos heteróticos e a designação de novas linhagens para o estabelecimento de grupos heteróticos são decisões importantes para qualquer programa de melhoramento de híbridos de milho. A maioria dos grupos heteróticos, se não todos, considerados importantes em milho foram estabelecidos empiricamente pela relação entre heteroses observadas nos cruzamentos e a origem dos genitores (Hallauer et al., 1988). Critérios de classificação foram também baseados em características morfológicas tais como tipo de endosperma (duro $x$ dentado), origem geográfica ou informações de genealogia. Isto levou a uma vaga definição de grupos heteróticos, porque a avaliação direta da heterose consome tempo e recursos, com muitos experimentos oriundos dos cruzamentos com vários testadores. 
O objetivo principal dos programas de melhoramento de milho é a identificação de linhagens que, quando cruzadas, resultem em híbridos expressando alto nível de heterose para produção de grãos. Muitos estudos têm fornecido evidências consistentes de que cruzamentos entre linhagens geneticamente divergentes produzem progênies superiores. Correlações positivas entre diversidade genética dos genitores, com produção de grãos da geração $F_{1}$ e heterose em milho foram encontrados por Moll et al. $(1962,1965)$ e Paterniani \& Lonquist (1963). A hipótese que explica o fenômeno da heterose é a da heterozigosidade atribuída a alelos dominantes (Jones, 1917) e a da sobredominância (East, 1936; Shull, 1952) a qual supõe que o estado heterozigoto em um único loco é superior a qualquer outro estado homozigoto. A implicação da heterozigosidade no fenômeno do vigor-híbrido sugere um potencial preditivo da heterose baseada na medida da distância entre genitores (Arcade et al. 1996).

A diversidade genética entre linhagens obtida com marcadores moleculares tem sido considerada como uma alternativa viável para predições das performances de híbridos e das heteroses dos cruzamentos. O princípio dessa técnica é a associação entre heterose e medidas indiretas de diversidade genética (isto é, diversidade morfológica, grau de parentesco e distâncias entre origens geográficas) reportadas para cruzamentos entre linhagens e, dentro de certos limites, para cruzamentos interraciais de milho (Hallauer et al., 1988). Dessa forma a teoria genética quantitativa mostrou que para qualquer grau de dominância maior que zero, a heterose se expressa nos cruzamentos em função das diferenças nas freqüências alélicas dos genitores (Falconer, 1981).

A heterose é o fundamento do melhoramento de híbridos de milho, mais pouco é conhecido sobre sua base genética. Dados experimentais acumulados desde os trabalhos publicados por Shull (1909) têm sugerido que a heterose para a produção de grãos e outras características é função da heterozigosidade em um grande número de locos. Aumentando o número de locos heterozigóticos pelo cruzamento de linhagens ou populações menos 
aparentadas aumenta-se o nivel de heterose observada nos cruzamentos (Moll et al., 1965). Dessa forma reduzindo-se o nível heterozigótico usualmente ocorre um decréscimo no vigor e na performance, efeitos conhecidos como depressão endogâmica (Hallauer \& Miranda Filho, 1988). Baseado na hipótese de associação entre heterose e freqüência de locos heterozigoticos afetando a característica, Hallauer et al. (1988), sugeriram a predição da heterose com o uso de marcadores moleculares.

\subsection{Predição das performances de híbridos simples de milho com marcadores bioquímicos e moleculares.}

Durante a década passada, dados de análises de isoenzimas, em combinação com dados de cromatografia de zeínas, foram extensivamente utilizadas para examinar a diversidade genética em germopasma de milho nos Estados Unidos, a partir de híbridos comercias, linhagens endogâmicas, populações exóticas de polinização aberta e coleções de germoplasma (Messmer et al., 1991). Esses estudos demonstraram a utilidade de dados de isoenzimas e cromatografias de zeínas para a avaliação em laboratório de linhagens e pureza dos híbridos como descritores adicionais para a identificação de cultivares e linhagens (Messmer et al., 1992).

As pesquisas também foram conduzidas para avaliar a utilidade das isoenzimas como critério de seleção e predição, e foram obtidos resultados variados. Hunter \& Kannenberg (1971) estudaram a utilização de isoenzimas para determinar se a variação entre linhagens endogâmicas de milho era indicativa das performances de seus híbridos. Eles caracterizaram 15 linhagens de milho com seis sistemas enzimáticos e utilizaram os dados para calcular o índice de diversidade. Os híbridos com os maiores índices de diversidade exibiram altas produções. Entretanto as correlações entre as performances dos híbridos simples e os índices de diversidade foram baixas e não significativas. 
Heidrich-Sobrinho \& Cordeiro (1975) utilizaram cinco sistemas enzimáticos na avaliação de oito raças de milho em cruzamentos dialélicos, para a produção de grãos. Encontraram correlações significativas entre diversidade genética das linhagens genitoras, obtidas com isoenzimas, e os híbridos $F_{1}$. Concluíram ainda que apesar do pequeno número de locos estudados (8) existem evidências de que esses alelos são bons marcadores da heterozigosidade.

Gonella et al. (1978) determinaram o grau de associação entre o grau de parentesco de sete linhagens endogâmicas de milho e a produção de grãos de seus híbridos simples. O grau de parentesco foi avaliado por três sistemas isoenzimáticos. A produção de grãos dos 21 híbridos simples foi avaliada experimentalmente em cinco locais, com duas repetições por local. As correlações entre as médias de produção de hibridos simples com os graus de parentesco das linhagens e as capacidades específicas de combinação foram relativamente pequenas e negativas. Concluiram que o grau de parentesco entre linhagens, utilizando isoenzimas, é de pouco ou nenhum valor preditivo, das performances de híbridos.

Frey et al. (1986) avaliaram o potencial de isoenzimas na avaliação de linhagens de milho representando diferentes germoplasmas. Para estimar as distâncias genéticas entre 406 linhagens e as 6 linhagens testadoras foram utilizados 21 locos de isoenzimas. As linhagens da mesma população foram consideradas da mesma genealogia. Diferentes grupos de linhagens foram utilizadas nos cruzamentos para a obtenção dos híbridos simples. Altas produções de grãos foram obtidas nos híbridos resultantes de cruzamentos de linhagens mais distantes. As correlações significativas foram observadas somente entre distâncias de aloenzimas e produção de grãos de híbridos oriundos de linhagens com genealogias similares.

Price et al. (1986) relacionaram as medidas de produção de grãos de híbridos simples de milho, oriundos dos cruzamentos de 48 linhagens endogâmicas, com as heterozigosidades em 13 locos polimórficos de 
isoenzimas. Os resultados obtidos mostraram que as performances dos cruzamentos não estavam associadas com o número de locos heterozigóticos.

Lamkey et al. (1987) avaliaram com isoenzimas 24 linhagens altamente produtivas e 21 de baixa produção, selecionadas a partir de suas produções relativas em um grupo de 247 linhagens endogâmicas de uma população de milho. Os híbridos obtidos das combinações entre e dentro de linhagens dos dois grupos foram avaliados para produção de grãos. Os genitores foram genotipados com 11 locos de isoenzimas para determinar se as diferenças alélicas nos locos de isoenzimas poderiam ser preditivas das performances de híbridos. Os resultados indicaram que as variações nas freqüências alélicas de isoenzimas não são indicativos das performances de híbridos obtidos de linhagens não selecionadas.

As isoenzimas foram utilizadas extensivamente nas análises de milho, porém este marcador apresenta algumas limitações, tais como o pequeno número de locos amostrados, aliado à limitada descrição das relações entre linhagens e híbridos de milho, e também aos poucos locos polimórficos no germoplasma elite (Melchinger et al., 1990a).

A exploração de polimorfismo ao nivel da variação na seqüência de bases do DNA foi proposta pela primeira vez no inicio da década passada (Botstein et al., 1980), quando as variações detectadas na seqüência do DNA foram chamadas de "polimorfismo (diferenças) no tamanho dos fragmentos de restrição" ou RFLP (Restriction Fragment Length Polymorphism). Desde então várias metodologias que revelam a existência de polimorfismos moleculares têm sido descritas na literatura. Em milho, existe atualmente um grande número de RFLPs mapeados (>500), bem distribuídos no genoma (Helentjaris et al., 1988; Burr et al., 1988; Coe et al. 1988) e que revelam um alto nivel de polimorfismo em germoplasmas elites (Godshalk et al., 1990., Smith et al., 1990; Melchinger et al., 1991; Boppenmaier et al., 1992). Entretanto, alguns trabalhos mostram que os resultados obtidos até hoje sobre a utilização de 
análises de RFLP para a predição de heterose, são de certa maneira contraditórios, e portanto, não podem ser considerados como definitivos.

Lee et al. (1989) avaliaram a viabilidade de utilização dos dados de RFLP para definir padrões heteróticos em 8 linhagens de milho. Foram avaliados 28 híbridos simples para a produção de grãos. A dispersão das linhagens e híbridos a partir das freqüências alélicas obtidas com RFLP foram consistentes com o esperado, baseado em dados de genealogia. A produção de grãos e a capacidade específica de combinação foram positivamente correlacionadas com as distâncias genéticas.

Godshalk et al. (1990) investigaram as relações entre distâncias genéticas obtidas com RFLP e os padrões heteróticos em um grupo de linhagens endogâmicas de milho. Um total de 22 linhagens foram cruzadas com 4 testadores em combinações que minimizaram os cruzamentos dentro de grupos heteróticos. Os resultados sugeriram que a análise RFLP é uma técnica valiosa para identificar grupos heteróticos, mas não eficaz na predição das performances de híbridos.

Melchinger et al. (1990b) compararam dois dialelos compostos de linhagens liberadas em 1950 e 1970 e avaliados para a produção de grãos e componentes de produção com relação a variação genética obtida com RFLP, heterose, efeitos epistáticos e utilidade das distâncias obtidas com RFLP na predição das heteroses e performances de híbridos simples. As linhagens liberadas em 1970 apresentaram maior produção e menor heterose. O agrupamento concordou com os dados de genealogia. As correlações entre distâncias genéticas geral e específica com heterose para produção de grãos e componentes de produção foram positivas mais de baixo valor preditivo.

Smith et al. (1990) estimaram as distâncias genéticas entre 37 linhagens elites representantes do germoplasma do "Corn Belt" de milho. Foram encontradas altas correlações com os coeficientes de parentesco. As distâncias genéticas foram também altamente correlacionadas com a produção de grãos $\mathrm{e}$ a heterose. Os coeficientes de determinação $\left(r^{2}\right)$ entre distâncias genéticas e 
coeficientes de parentesco, produção de grãos e heterose foram altos $(0,81$, 0,87 e 0,77 , respectivamente). A análise de agrupamento alocou as linhagens em famílias de acordo com o histórico do melhoramento e as respostas heteróticas.

Bernardo (1992) examinou as relações teóricas entre a heterozigosidade estimada com dados de marcador RFLP e de isoenzimas nas linhagens genitoras com as performances de híbridos simples de milho, avaliados para produção de grãos, capacidade geral e específica de combinação. As correlações entre distâncias genéticas obtidas com marcador e performances de híbridos foram baixas $(r<0,25)$. As correlações entre capacidade específica de combinação e heterozigosidade específica do marcador molecular foram altas. As correlações entre capacidade geral de combinação e heterozigosidade geral do marcador molecular foram altas ou baixas, dependendo das freqüências alélicas das linhagens testadas.

Boppenmaier et al. (1992) avaliaram 11 linhagens de milho duro, 11 linhagens de milho dentado e 66 híbridos $F_{1}$ em um fatorial incompleto. Os híbridos foram avaliados para qualidade e produção de forragem. Os agrupamentos foram consistentes com os grupos heteróticos e as informações de genealogia. As distâncias genéticas apresentaram médias maiores nos cruzamentos entre grupos do que dentro de grupos (duro $x$ duro ou dentado $x$ dentado). As distâncias genéticas, geral ou específica, não foram correlacionadas com as performances de $F_{1}$ ou heterose, para nenhuma característica avaliada.

Melchinger et al. (1992) investigaram as relações entre as distâncias genéticas estimadas com RFLP, as performances de híbridos simples e as heteroses de 6 linhagens de milho duro e 6 dentado, avaliadas em cruzamento dialélico para características forrageiras. Os agrupamentos baseados em RFLP separaram as linhagens nos respectivos grupos heteróticos e de acordo com as informações de genealogia. As correlações entre distâncias genéticas com as performances do $F_{1}$, heterose e capacidade específica de combinação para 
produção de matéria seca da espiga, forragem e palha, foram positivas e de magnitudes moderadas, quando comparado com as altas correlações de distâncias genéticas específicas com essas características. As correlações foram menores entre grupos heteróticos (duro $x$ dentado), positiva e significativa dentro de grupos (duro $x$ duro) e ineficaz nos cruzamentos dentado $x$ dentado, devido à falta de variação genotípica.

Boppenmaier et al. (1993) utilizaram marcadores RFLP para predizer o potencial de produção de diferentes tipos de cruzamentos. Avaliaram 15 linhagens de milho duro, 12 linhagens de milho dentado e 68 cruzamentos $F_{1}$ produzidos entre eles. As distâncias genéticas estimadas nas linhagens parentais separaram os dois grupos heteróticos de acordo com as informações de genealogia. Quando se considerou todos os cruzamentos, as correlações entre as distâncias genéticas com as performances de $F_{1}$ e heterose foram significativas para todas as características, exceto para a performance de $F_{1}$ no conteúdo de matéria seca. As correlações foram significativas entre distâncias genéticas e performances de $F_{1}$ e heterose nos cruzamentos duro $x$ duro, mas não nos cruzamentos duro $x$ dentado ou dentado $x$ dentado.

Charcosset et al. (1991) estudaram a correlação entre as distâncias genéticas de duas linhagens genitoras e as heteroses observadas entre elas. $A$ distribuição uniforme dos alelos por todo o genoma das linhagens foi necessária para a obtenção das correlações devido ao desequilibrio de ligação entre os locos marcados e QTL. A conclusão desse trabalho foi que a predição da heterose de híbridos $F_{1}$ baseados em locos marcadores de DNA são eficientes se houver uma seleção prévia de marcadores relacionados aos alelos implicados na característica considerada.

Charcosset \& Essiou (1994) avaliaram as relações entre heterozigosidade $\mathrm{e}$ as heteroses dos híbridos $F_{1}$ de milho. Os resultados mostraram que a condição necessária para haver correlação entre heterozigosidade e heterose é o desequilibrio de ligação entre os marcadores e os locos relacionados a heterose. As correlações entre heterozigosidade e 
heterose considerados todos os híbridos e dentro de grupos heteróticos foram significativas. A nível de subgrupo nenhuma correlação significativa foi observada. As correlações aumentaram com o aumento do número de marcadores utilizados nas análises.

Bernardo (1994) avaliou as relações entre as performances de híbridos simples de milho para a produção de grãos, utilizando o BLUP (Best linear unbiased prediction) com os dados do marcadores RFLP obtidos nas linhagens genitoras e os dados de produção de grãos dos híbridos. Foram observadas altas correlações $(0,65$ a 0,80$)$ entre os valores de produção de grãos preditos e observados. As correlações foram maiores quando a variância da dominância foi incluída no modelo ou quando os coeficientes de coancestralidade foram determinados com os dados de RFLP ao invés dos dados de genealogia. As correlações permaneceram estáveis nos diferentes cruzamentos, representando diferentes magnitudes de variâncias genéticas.

Smith et al. (1994) mostraram que dados gerados a partir de 20 combinações de "primers" AFLP em 35 linhagens endogâmicas de milho foram altamente correlacionados com a produção de grãos de híbridos simples ( $r=$ $0,91)$, heterose $(r=0,84)$, genealogia $(r=0,90)$ e dados de RFLP $(r=0,91)$. Houve concordância nos agrupamentos obtidos com o marcador AFLP em comparação com agrupamentos gerados com dados do marcador RFLP e a genealogia.

Bernardo (1997) avaliou as performances dos cruzamentos testes de 15 linhagens irmãs obtidas da autofecundação de três linhagens derivadas de cinco populações $F_{2}$ e alocadas em cinco grupos heteróticos. As contribuições dos genitores para as 15 linhagens irmãs foram avaliadas com 70 locos RFLPs e os dados utilizados para estimar o coeficiente de coancestralidade. As correlações entre performances observadas e preditas foram baixas para a maioria das características avaliadas nos híbridos. A correspondência entre capacidade geral de combinação observada e predita, das linhagens irmãs, foi de baixo valor. Os resultados sugerem que a proporção do genoma derivado 
dos genitores para as linhagens irmãs não é suficiente para determinar as performances dos cruzamentos testes. Isto indica que as avaliações experimentais continuam sendo necessárias para a avaliação preliminar das linhagens irmãs.

Lanza et al. (1997) avaliaram as mesmas 18 linhagens de milho utilizadas nesse trabalho com 32 pares de "primers" RAPD. Os grupos encontrados no dendrograma não concordaram totalmente com as informações de grupos heteróticos previamente definidos com base na genealogia. As correlações entre distâncias genéticas e produção de grãos dos híbridos simples, considerando os grupos heteróticos, foram de baixo valor preditivo $(r=$ $0,16)$.

Ajmone-Marsan et al. (1998) avaliaram as divergências genéticas em 13 linhagens endogâmicas de milho utilizando 209 fragmentos polimórficos de AFLP e 135 de RFLP e estudaram as relações entre as distâncias genéticas e as performances dos híbridos. A análise de agrupamento concordou com as informações de genealogia. A correlação entre distâncias genéticas e performances do $F_{1}$ para a produção de grãos foi positiva mais de baixo valor preditivo; entretanto, a correlação entre distâncias genéticas específicas e capacidades específicas de combinação para a produção de grãos foi alta o suficiente para ter um valor preditivo.

Chowdari et al. (1998) avaliaram a diversidade genética em cinco linhagens com esterilidade citoplasmática e sete linhagens restauradoras em milheto, usando SSR e RAPD. Um total de 160 locos polimórficos foram gerados e o índice de similaridade variou de 0,50 a 0,81. O agrupamento concordou com as relações de genealogia. As performances dos genitores e dos híbridos foram avaliados para características produtivas e vegetativas. As correlações entre distâncias genéticas e performances de híbridos não foram significativas para a maioria das características avaliadas. Os resultados indicaram que os microssatélites e RAPD são úteis para agrupamento de genitores, mas não como preditores de combinações heteróticas em milheto. 
Benchimol et al. (2000) avaliaram as distâncias genéticas estimadas com o marcador RFLP, entre 18 linhagens oriundas das populações BR105 e BR106, e suas capacidades de alocar os híbridos em grupos heteróticos e predizer as suas performances. As duas populaçōes foram agrupadas de acordo com os grupos heteróticos definidos previamente (genealogia). As correlações entre as distâncias genéticas dos genitores e as heteroses foram altas para linhagens do mesmo grupo heterótico e baixas para linhagens de diferentes grupos heteróticos. Portanto as distâncias genéticas não foram capazes de predizer as performances dos híbridos obtidos de grupos heteróticos diferentes.

Wu (2000) avaliou as distâncias genéticas estimadas com AFLP e RAPD em 70 linhagens de milho utilizadas em programas de melhoramento na China e correlacionou-as com as performances de híbridos. Os agrupamentos obtidos com os dois marcadores alocaram as 17 linhagens genitoras em cinco grupos, de acordo com as informações de genealogia. As distâncias entre os grupos foram maiores do que aquelas dentro de grupos. As correlações entre distâncias genéticas com a produção de grãos da geração $F_{1}$, heterose e capacidade específica de combinação dos 136 híbridos foram significativas e positivas.

Os marcadores AFLP e microssatélites (SSR) recentemente descobertos estão sendo comparados com marcadores RAPD e RFLP para alocar linhagens e populações em grupos heteróticos e predizer as performances de híbridos em espécies como milho, soja e girassol. Marcadores como SSR e AFLP tem se mostrado mais vantajosos nesses estudos devido a seu maior conteúdo informativo e ao índice de eficiência da análise, respectivamente. Dessa forma SSR e AFLP poderiam substituir o RFLP e RAPD em estudos de similaridade genética, devido à sua comparável acurácia em genotipar linhagens endogâmicas de milho selecionadas por genealogia. 


\subsection{Marcador AFLP: princípio e aplicação da técnica}

O AFLP (Amplified fragment lenght polymorphism) é um marcador molecular altamente eficiente quando comparado com outros sistemas marcadores de DNA (Powell et al., 1996; Russel et al., 1997; Pejic et al., 1998), embora seu conteúdo de polimorfismo esteja entre os mais baixos, devido à sua natureza predominantemente dominante. Até o momento, a técnica de AFLP tem sido utilizado com sucesso para avaliar a diversidade genética de muitas espécies de plantas, incluindo o milho (Ajmone-Marsan et al., 1998; Pejic et al., 1998), cevada (Russel et al., 1997; Schut et al., 1997) trigo (Barret et al., 1998), batata (Milbourne et al., 1997), arroz (Zhu et al., 1998) e soja (Maughan et al., 1996). Devido à alta razão multiplex da análise AFLP, um grande número de marcadores podem ser acumulados rapidamente sem muito esforço. A técnica permite a geração de 50-100 fragmentos genômicos por reação, dos quais até $50 \%$ podem ser marcadores em potencial. Além disso, tanto marcadores dominantes como codominantes podem ser encontrados. A marcação de diferentes alelos em um loco particular não é obvia, implicando que o conteúdo informativo é muito baixo. Para estudos em que a alta razão multiplex é mais importante que o conteúdo informativo, o AFLP é muito útil. Embora a técnica de amplificação de DNA seja mais vantajosa que os marcadores clássicos, todos eles tem suas limitações e aplicações específicas que podem determinar a seleção do sistema marcador para cada questão a ser respondida. Se o objetivo é "fingerprinting" ou a avaliação da diversidade genética, métodos com alta razão multiplex são apropriados desde que sejam amostrados os locos distribuídos ao acaso. O AFLP foi delineado a partir do RFLP (Tanksley et al., 1989) e PCR (Williams et al., 1990). As análises AFLP e RFLP são técnicas similares; entretanto, o AFLP envolve a detecção de presença e ausência de fragmentos de restrição ao invés de diferenças no tamanho do fragmento, e detecta simultaneamente mutações de ponto (David et al., 1998). A análise AFLP é mais simples que a dos microssatélites, desde que não requer 
conhecimento a "priori" da seqüência. O AFLP é um meio efetivo de se detectar muitos polimorfismos em um único gel. Todas as evidências até agora indicam que eles são reproduziveis como o RFLP. Em comparação com o RAPD, o AFLP requer menos DNA por reação, é tecnicamente mais informativo e a sua automação e a disponibilidade de "kits" torna a tecnologia de alto nível.

A principal vantagem do AFLP é a amplificação com geração de um grande número de locos por reação; isso se deve a combinação das diferentes enzimas de restrição e de nucleotídeos seletivos nos "primers" utilizados nas amplificações, e a resolução dos géis de sequenciamento. Um grande número de locos pode ser obtido com poucas combinações de "primers", sem a necessidade de informação "a priori" das seqüências, a técnica é altamente reproduzível com a obtenção de um grande número de locos em curto espaço de tempo. A técnica pode ser aplicada a um grande número de amostras a serem automatizadas. Em combinação com a separação de fragmentos em gel de poliacrilamida pode haver a redução na tendência da estimativa genética devido a obtenção de dados imprecisos, pela marcação de fragmentos de tamanhos diferentes como similares. O AFLP tem algumas desvantagens, como o requerimento de um investimento inicial com infra-estrutura, o marcador é predominantemente dominante e nesse caso a informação da heterozigosidade é perdida; no caso de marcação radiativa, a técnica se torna cara e perigosa. Uma crítica muitas vezes levantada em oposição ao uso do AFLP é que as localizações das bandas não são conhecidas (não foram mapeadas). Dessa forma é possível que estejam agrupadas em algum local e que não representem o genoma como um todo (Law et al., 1998).

Uma crítica corrente também feita ao uso do AFLP não mapeado para análise de diversidade de cereais é que eles tendem a se agrupar em áreas de baixa recombinação como as regiões pericentroméricas, as quais tem um alto conteúdo de DNAs repetitivos (Moore et al., 1993), não representando então variáveis independentes e não fornecendo a cobertura do genoma. Hayes et al. citados por Law et al. (1998), reportaram esse fenômeno em cevada quando 
foram feitas tentativas de mapear um substancial número de AFLP ECO/MSE. Entretanto, esses autores reconhecem a necessidade do uso de enzimas insensiveis à metilação para gerar fragmentos de fração repetitiva, já que mais de $80 \%$ do genoma dos cereais consistem de DNAs repetitivos altamente metilados.

\subsection{Marcador microssatélite: princípio e aplicação da técnica}

Os microssatélites são também conhecidos como SSRs (Simple Sequence Repeat), entre outras denominações e, consistem numa subclasse de DNA repetitivo formado por pequenas seqüências (2 a 5 nucleotídeos) em tandem, tais como (AT)n, (ATT)n, etc. Devido à sua natureza repetitiva, esses marcadores geram um modelo complexo de bandas. Esses marcadores têm sido utilizados com sucesso na determinação da variação genética em plantas (Rogstad et al., 1988; Nybom, 1990; Amos \& Pemberton, 1992; Beyermann et al., 1992; Zhou \& Gustafson, 1995) e estudos filogenéticos (Gebhardt et al., 1989; Jung et al., 1993). A variação no número de repetições (n) destas seqüências gera uma grande quantidade de polimorfismos, tornando-os bastante atrativos para estudos genéticos. A hipervariabilidade dos microssatélites não é totalmente desconhecida e pode ser originada por "crossing-over" desigual ou "slippage", durante a replicação do DNA (Levinson \& Gutman, 1987). Dado que a geração dessas seqüências por "slippage" é efetivamente um processo neutro, espera-se que estes microssatélites estejam distribuídos ao acaso por toda a região eucromática do genoma. Na prática, esse polimorfismo é detectado através de uma amplificação exponencial em cadeia (PCR) a partir de "primers" complementares às seqüências adjacentes aos microssatélites, de forma a gerar um produto de amplificação normalmente inferior a 300 pares de bases, seguido por fracionamento em gel de agarose ou de poliacrilamida, dependendo do tamanho do fragmento amplificado. 
A descoberta de minissatélites (Jeffreys et al., 1985) deu origem aos RFLPs multilocos pelo uso de seqüências "core" como probe. Devido a sua eficiência na identificação genética, esta técnica foi denominada "fingerprinting" genômico e foi também estendida para DNAs repetitivos. Em geral esses marcadores são classificados em três grupos: 1- "probe" repetido M13 (Rogstad et al., 1988); 2- seqüência simples repetida (Tzuri et al., 1991) e 3- DNAs minissatélites (Dallas, 1988).

Os microssatélites têm as vantagens de serem menores, altamente reproduzíveis, locos específico, codominantes e sua hipervariabilidade permite o uso de qualquer população segregante como referência para estudos de ligação.

A aplicação dos microssatélites em pesquisa vegetal é relativamente recente (Morgante \& Olivieri, 1993; Bell \& Ecker, 1994; Cregan et al., 1994). Recentemente, foi documentada uma análise da presença de seqüências microssatélites em milho (Chin et al., 1996), a qual foi utilizada para estudos de germoplasma, mapeamento genômico (Senior \& Heun, 1993; Taramino \& Tingey, 1996) e diversidade (Ramash et al., 1995). Smith et al. (1997) encontraram alta concordância entre linhagens de milho avaliadas com marcadores SSR, RFLP e genealogia. Esses estudos indicaram a eficiência dos microssatélites para a identificação de germoplasma e análise de genealogia.

Como pode ser observado, existem poucos trabalhos que correlacionam distâncias genéticas estimadas com marcadores AFLP e SSR, com as performances dos híbridos de milho. Outra observação é que praticamente a maioria dos estudos foi conduzido com material de base genética estreita (linhagens de clima temperado), e apenas os trabalhos de Benchimol et al. (2000) e Lanza et al. (1997), avaliaram as performances per se e heteroses de híbridos oriundos de linhagens de milho tropical, com marcadores de DNA. A ampliação dos estudos com material de base genética ampla (linhagens de clima tropical) será importante para um melhor conhecimento deste material, tanto com relação à diversidade genética 
existente, como quanto a utilização dos dados de diversidade genéticas obtidas com marcadores AFLP e SSR para à predição de híbridos. 


\section{MATERIAL E MÉTODOS}

\subsection{Descrição das populações}

Neste estudo foram utilizadas 18 linhagens $S_{3}$ de milho pertencentes às populações BR-105 e BR-106. A população BR-105, da qual foram tomadas oito linhagens, caracteriza-se por apresentar grãos semi-duros de coloração alaranjada, porte baixo, ciclo precoce e baixa depressão por endogamia. A população BR-106, que forneceu 10 linhagens, possui porte baixo, ciclo precoce e grãos amarelos dentados. Essas populações foram desenvolvidas pelo Centro Nacional de Milho e Sorgo - CNPMS/EMBRAPA. A população BR105, denominada inicialmente de Suwan, foi obtida na Tailândia pela seleção de progênies $S_{1}$ e após sua introdução no Brasil foi submetida a cinco ciclos de seleção com progênies de irmãos germanos. A BR-106 foi obtida pelo intercruzamento das variedades Centralmex, Composto Dentado e Maya, com o BR-108 (Tuxpeño-1) e em seguida submetida a duas gerações de recombinação seguidos de três ciclos de seleção para redução da altura de planta e espiga (Souza Jr. et al., 1993). A população BR-105 quando cruzada com a BR-106 apresenta alto nivel de heterose. Dessa forma essas duas populações foram alocadas em grupos heteróticos distintos (Naspolini $F^{0}$ et al. 1981; Souza Jr. et al. 1993). 


\subsection{Material básico}

Inicialmente 400 linhagens $S_{3}$ de cada população (BR-105 e BR-106) foram submetidas à seleção para capacidade de combinação com aspopulações recíprocas. A seguir 40 linhagens superiores de cada população foram avaliadas quanto ao comportamento per se, de onde foram selecionadas oito linhagens elites da população BR-105 e dez da BR-106, que constituem o material básico do presente trabalho. As linhagens de cada população encontram-se descritas na Tabela 1.

Tabela 1 . Linhagens de milho pertencentes às populações BR-105 e BR-106.

\begin{tabular}{lll}
\hline Linhagens & Identificação & Genealogia \\
\hline L01 & BR105-01 & 05.01.4B \\
L02 & BR105-02 & 05.05.2A \\
L03 & BR105-03 & 05.17.1A \\
L04 & BR105-04 & 05.18.6A \\
L05 & BR105-05 & 05.19.1B \\
L06 & BR105-06 & 05.23.2B \\
L07 & BR105-07 & 05.33.5B \\
L08 & BR105-08 & 05.34.2B \\
L09 & BR106-09 & $06.03 .5 B$ \\
L10 & BR106-10 & 06.06.3A \\
L11 & BR106-11 & 06.08.1A \\
L12 & BR106-12 & 06.08.2A \\
L13 & BR106-13 & $06.14 .4 B$ \\
L14 & BR106-14 & 06.24.7B \\
L15 & BR106-15 & 06.28.1A \\
L16 & BR106-16 & $06.29 .7 B$ \\
L17 & BR106-17 & $06.37 .5 B$ \\
L18 & BR106-18 & $06.44 .1 B$ \\
\hline
\end{tabular}

Fonte: Lanza et al. (1997) e Pinto (2000). 


\subsection{Avaliação experimental das linhagens em cruzamentos dialélicos}

As oito linhagens da BR-105 e dez da BR-106 foram intercruzadas em um esquema dialélico produzindo 80 híbridos interpopulacionais e 73 intrapopulacionais (28 da população BR-105 e 45 da BR-106).

Os 80 híbridos interpopulacionais foram avaliados, em conjunto com 20 híbridos comerciais, em experimentos em látice $10 \times 10$. Os experimentos foram realizados em duas épocas diferentes, nos anos agrícolas 1992/93, em três localidades de Piracicaba/SP, com duas repetições por local: área experimental da Escola Superior de Agricultura "Luiz de Queiroz" de Agronomia (ESALQ/USP), Fazenda Areão e Fazenda Caterpillar. Os híbridos intrapopulacionais foram avaliados em experimentos em látice $9 \times 9$, em conjunto com oito híbridos comerciais. Os experimentos foram realizados na Fazenda Caterpillar, nos anos agrícolas de 1992/93, e Fazenda Areão e Fazenda Caterpillar em 1993/94, com três repetições por local. Em todos os experimentos as parcelas foram constituídas de linhas de 4 metros, espaçadas de $0,90 \mathrm{~m}$ e com 0,20m entre plantas, contendo 20 plantas no estande ideal.

Para as finalidades desse trabalho foram utilizados os dados de médias e heteroses de produção de grãos que está apresentado em Lanza et al. (1997) e Pinto (2000):

\subsection{Avaliação das linhagens em laboratório}

\subsubsection{Preparação do material vegetal e extração do DNA}

Para preparação do material vegetal para extração do DNA total foram semeadas vinte sementes (cinco sementes por saco de plantio) de cada linhagem em casa de vegetação. Folhas obtidas de plantas com 6 a 8 semanas 
foram coletadas, liofilizadas e moídas. Para cada linhagem foram misturadas quantidades iguais de material vegetal das vinte plantas.

O DNA foi extraído segundo o protocolo Saghai-Maroof et al. (1984) onde $300 \mathrm{mg}$ de material foliar liofilizado e moído foi dissolvido com $9 \mathrm{ml}$ de CTAB (Tris-Nacl/Nacl/EDTA/ $\mathrm{H}_{2} \mathrm{O} / \mathrm{BME}$ ) a $65^{\circ} \mathrm{C}$ por $90 \mathrm{~min}$. Após resfriamento à temperatura ambiente foi então adicionado $4,5 \mathrm{ml}$ de clorofórmio:álcool:isoamílico (24:1) e centrifugado por 10 minutos a 25.000 rpm. O sobrenadante foi retirado e depositado em um novo tubo Falcon de $15 \mathrm{ml}$. Foi feita uma nova extração com $4,5 \mathrm{ml}$ de clorofórmio:álcool:isoamílico a 25.000 rpm por 10 minutos.

O sobrenadante foi retirado e colocado em um novo tubo contendo 25 $\mu l$ de RNase $(10 \mathrm{mg} / \mathrm{ml})$ ficando em repouso a temperatura ambiente por 1:30 hs. Após esse tempo foi adicionado $6 \mathrm{ml}$ de isopropanol (2-propanol), misturando-se até o completo enovelamento do DNA. O DNA foi removido com o auxílio de um gancho de vidro e imerso em uma solução para lavagem (76\% EtoH, 0,2 M NaOAc) por 20 minutos e em seguida na solução (76\% EtoH, 10 $\mathrm{mM}$ NH4Oac). O DNA foi então dissolvido em $1 \mathrm{ml}$ de TE (Tris $10 \mathrm{mM}(\mathrm{pH} \mathrm{0,8)}$ e EDTA 0,1 mM).

Foi feita uma nova extração com fenol:clorofórmio:álcool isoamílico (25:24:1) na proporção de $1: 1$ a $10.000 \mathrm{rpm}$ por 5 minutos. O DNA foi novamente extraído em clorofórmio:álcool isoamílico (24:1) e precipitado em 75 $\mu l$ de $\mathrm{NaCl} 5 \mathrm{M}$ e $3,75 \mathrm{ml}$ de etanol absoluto, lavado nas duas soluções de lavagem citadas anteriormente e re-suspendido em $1 \mathrm{ml}$ de TE (Tris pH 8.0, 10 $\mathrm{mM}$; EDTA pH 8,0, 1mM).

A quantificação foi feita com a utilização do espectrofotômetro e gel de agarose $0,8 \%$ por comparação com padrões de pesos específicos conhecidos (DNA $\lambda$ ). A estimativa da concentração foi feita através dos valores obtidos com os dois métodos. Optou-se pelo método de gel de agarose para quantificação do DNA complementado pelo expectrofômetro para análise da pureza dos mesmos. 
As concentrações de DNA variaram de 250 a $1250 \mathrm{ng}$ por $300 \mathrm{mg}$ de folha liofilizada e moída utilizadas nas extrações.

\subsubsection{Amplificações AFLP}

O AFLP "fingerprinting" foi produzido para cada linhagem utilizando o protocolo descrito por Vos et al. (1995). Foram efetuados vários testes para otimização do protocolo. Estes testes envolveram: estabelecimento da quantidade de DNA a ser utilizada na reação; comparação entre resultados obtidos após marcação do "primer" para as amplificações com o radioisótopo marcado com $\gamma \mathrm{P}^{32}$ e $\gamma \mathrm{P}^{33}$ e testes de reprodutibilidade dos resultados.

Foram utilizados $300 \mathrm{ng}$ de DNA genômico na digestão com 2,5U de ECORI e de MSE. Após o corte, adaptadores de dupla fita foram ligados nas extremidades do fragmento do DNA com o auxílio da T4 DNA ligase. Dessa forma a seqüência adjacente ao sítio de restrição e os adaptadores serviram como sitio de ligação do "primer" para a subseqüente amplificação dos fragmentos de restrição (Vos et al., 1995). Um nucleotídeo seletivo foi usado na reação de pré-amplificação e três nucleotídeos na reação de amplificação seletiva.

As reações de digestão, ligação dos adaptadores, reações de préamplificações, marcações dos "primers" e amplificações seletivas foram seguidas conforme o protocolo, com pequenas modificações. As reações de pré-amplificação usadas nas amplificações seletivas foram diluídas na concentração de 1:25. Todos os adaptadores e "primers" utilizados foram provenientes da Life Technologies (Gibco BRL) incluída no "AFLP Analysis System I". Foram utilizadas 20 combinações de "primers" descritas previamente para milho: EAAC/MCAC; EAAC/MCAG; EAAC/MCAT; EAAC/MCTA; EAAC/MCTC; EAAC/MCTG; EAAC/MCTT; EAAC/MCAA; EAAC/MCAC; EAAG/MCAG; EAAG/MCAT; EAAG/MCTC; EAAG/MCTG; EAAG/MCTT; EACAMMCAC; EACAMCAG; EACAMCAT; EACA/MCTA; EACA/MCTC; 
EACA/MCTG. As amplificações foram feitas segundo as instruções do manual do Kit de AFLP.

Após o PCR um igual volume de formamida (98\%de formamida, 10 mM EDTA pH 8,0 e os corantes bromofenol azul e xileno cyanol) foi adicionado em cada reação. As amostras foram denaturadas a $90^{\circ} \mathrm{C}$ por 3 minutos e colocadas no gelo. Cada amostra ( $2 \mathrm{ul}$ ) foi carregada em um gel denaturante de poliacrilamida $6 \%$ (Cho et al., 1996) com espaçadores $0.4 \mathrm{~mm}$. A matriz foi preparada usando $6 \%$ de bisacrilamida, uréia $7 \mathrm{M}$ e TBE $0.5 \mathrm{X}$. Para $100 \mathrm{ml}$ de solução de gel foi adicionado $500 \mu$ l de persulfato de amônia e $100 \mu$ l de TEMED.

A eletroforese foi conduzida no SequiGen $38 \times 50 \mathrm{~cm}$ (BioRad Laboratories Inc., Hercules Calif., USA). O tampão de corrida consistiu de TBE 0.5X. A eletroforese foi feita a uma voltagem constante de $75 \mathrm{~W}$ por 4 horas e $25 \mathrm{~W}$ por 2:30 hs. Após a eletroforese o gel foi seco aderido em papel whatman $3 \mathrm{MM}$ (Maisdstone, Kent, England, UK) a $80^{\circ} \mathrm{C}$ por 1 hora.

O gel foi exposto a filme autorradiográfico por um período de 72 horas. A leitura das bandas foi feita visualmente com o auxílio do transluminador.

As bandas foram codificadas com "0" ou "1" para ausência e presença, respectivamente, para posterior análise dos dados.

\subsubsection{Amplificações SSR}

Nas reações de microssatélites foram utilizados 40ng de DNA, tampão da enzima 10X ( $\mathrm{Kcl} 50,0 \mathrm{mM}, \mathrm{MgCl}_{2} 1,5 \mathrm{Mm}$, Tris- $\mathrm{HCl} 10,0 \mathrm{mM}, \mathrm{pH} 9,0$ a $25^{\circ} \mathrm{C}$ e $0,1 \%$ de Triton $X-100), \mathrm{MgCl}_{2} 25 \mathrm{mM}, 2,5 \mathrm{mM}$ de cada dNTPS (desoxinucleosídeotrifosfato) e $5 \mathrm{U} / \mathrm{ul}$ de Taq polimerase (pharmacia) e concentrações de "primers" que variaram de 0,2 $\mu \mathrm{M}, 0,4 \mu \mathrm{M}, 0,6 \mu \mathrm{M}, 0,8 \mu \mathrm{M}$ e 1 $\mu \mathrm{M}$ para cada par de "primers" (Maize MapPairs ${ }^{\mathrm{TM}}$; Research Genetics) em um volume final de $20 \mu \mathrm{l}$. 
A seleção de "primers" foi feita testando-se inicialmente 235 "primers" com concentração de 0,2 $\mu \mathrm{M}$ para cada par e o programa "Touchdown" PCR (Tabela 2) segundo o protocolo de Senior et al. (1996) com algumas modificações e com DNAs de três linhagens selecionadas ao acaso das duas populações. Dos 235 "primers" testados foram selecionados 80 dentre os quais 60 exibiram bandas bem definidas dentro de cada linhagem, como resultado das amplificações. Os outros 20 "primers" selecionados foram novamente testados mudando-se, inicialmente, somente a concentração naqueles que apresentaram duas bandas dentro de cada linhagem, mas com fraca resolução. Os "primers" que apresentaram bandas múltiplas, não definidas ou falta de amplificação foram novamente testados mudando-se a temperatura de anelamento de cada um e a sua concentração.

A temperatura de anelamento foi estimada baseada nas seqüências de base de cada par de "primers" ("reverse/forward") disponiveis em http:Iluwww.agron.missouri.edu (Maize Cooperation in Genomics and Genetics). A temperatura de anelamento foi calculada segundo a fórmula $T_{A}=\left[2{ }^{\circ} \mathrm{C} x\right.$ (Adenina + Timina $)+4{ }^{\circ} \mathrm{C} \times$ (Citosina + Guanina $)-5^{\circ} \mathrm{C}$, descrita por Newton \& Graham (1997). A temperatura de anelamento inicial foi estabelecida considerando o valor igual ou acima da maior $T_{A}$ do par de "primers reverse/forward" e o valor final abaixo ou próximo do menor valor do par. Porém as amplificações na maioria dos locos continuaram com bandas múltiplas e/ou sobrepostas. Considerou-se, portanto, os critérios adotados por Ogliari (1999), com temperaturas iniciais de anelamento superiores a do par de "primers". Utilizou-se então temperaturas que variaram de 70-65, 65-55 e 55-50 (Tabela 3). Dessa forma o programa ficou definido inicialmente com um passo de denaturação inicial de 2 min a $94^{\circ} \mathrm{C}$, em seguida ciclos de desnaturação a $94^{\circ} \mathrm{C}$ por $30 \mathrm{~s}$, anelamento de $30 \mathrm{~s}$ com redução de $1{ }^{\circ} \mathrm{C}$ a cada dois ciclos em função da temperatura de anelamento utilizada e extensão de 1 min a $72{ }^{\circ} \mathrm{C}$. Esta etapa da amplificação foi repetida 20 vezes e submetida a uma nova etapa de amplificação com passos de denaturação, anelamento e extensão de $94{ }^{\circ} \mathrm{C}$ 
por $30 \mathrm{~s}, 55^{\circ} \mathrm{C}$ por $30 \mathrm{~s}$ e $72{ }^{\circ} \mathrm{C}$ por $1 \mathrm{~min}$, respectivamente, por 18 vezes. Seguiu-se uma etapa de extensão final de $72{ }^{\circ} \mathrm{C}$ por 2 min e imersão por $15^{\circ} \mathrm{C}$. Dos 20 "primers" testados foram ajustados oito, totalizando um total de 68 pares de "primers" ajustados as linhagens de milho.

Tabela 2. Programa de amplificação "Touchdown PCR" modificado.

\begin{tabular}{clcc}
\hline Etapas & \multicolumn{1}{c}{ Passos } & Temperatura & Tempo \\
\hline 01 & Desnaturação inicial & $94^{\circ} \mathrm{C}$ & $2 \mathrm{~min}$ \\
$\mathbf{0 2}$ & Desnaturação & $94^{\circ} \mathrm{C}$ & $30 \mathrm{~s}$ \\
& Anelamento & $65^{\circ} \mathrm{C}\left(-1^{\circ} \mathrm{C} /\right.$ ciclo $)$ & $30 \mathrm{~s}$ \\
& Extensão & $72^{\circ} \mathrm{C}$ & $1 \mathrm{~min}$ \\
03 & Desnaturação & $94^{\circ} \mathrm{C}$ & $30 \mathrm{~s}$ \\
& Anelamento & $55^{\circ} \mathrm{C}$ & $30 \mathrm{~s}$ \\
& Extensão & $72^{\circ} \mathrm{C}$ & $1 \mathrm{~min}$ \\
04 & Extensão final & $72^{\circ} \mathrm{C}$ & $2 \mathrm{~min}$ \\
\hline
\end{tabular}

As amplificações foram feitas no termociclador modelo PTC-100 (Programable Thermal Controller, MJ Research Inc.) utilizando microtubos com capacidade de 0,5 ul. Os fragmentos foram resolvidos em gel de agarose/metaphor (1:1) com concentração de $4 \%$ e preparado com tampão TBE 1X (0,09 M Tris-borato e 2,0 mM EDTA). A eletroforese foi conduzida a uma voltagem constante de $100 \mathrm{~V}$ por aproximadamente 2:30 min. Os géis foram carregados com $10 \mu \mathrm{l}$ de cada reação com adição de $2 \mu \mathrm{l}$ de tampão de carregamento $(0,25 \%$ de azul de bromofenol, $0,25 \%$ de xileno cyanol e $30 \%$ de glicerol com água) e com o padrão $\phi \times 174$ digerido com Hinfl de peso molecular conhecido. Após a eletroforese os géis foram corados com brometo de etídio 
$(0,5 \mu \mathrm{g} / \mathrm{ml})$ por 20 minutos e lavados com água destilada. O géis foram visualizados em luz ultravioleta e fotografados com câmara polaroid. As bandas foram inicialmente codificadas com "1" ou " 0 " para presença e ausência, respectivamente, e depois foram lidas como dados genotípicos, de forma a identificar todos os locos e alelos.

\subsection{Análises estatísticas utilizando os dados obtidos com os marcadores}

\subsubsection{Cálculo das distâncias genéticas utilizando o marcador AFLP}

Para o marcador AFLP as distâncias genéticas entre os pares de linhagens foram calculadas a partir dos dados binários, utilizando o complemento aritmético do coeficiente de Jaccard (Jaccard, 1908), no programa NTSYS versão 2.0:

$$
D_{(i, j)}=1-\frac{N i j}{N i+N j+N i j}
$$

em que:

$D_{(i, j)}=$ distância genética entre as linhagens i e j;

$\mathrm{N}_{\mathrm{ij}}=$ número total de bandas comuns as linhagens i e j;

$\mathrm{N}_{\mathrm{i}}=$ número de bandas presentes somente na linhagem $\mathrm{i}$;

$\mathrm{N}_{\mathrm{j}}=$ número de bandas presentes somente na linhagem $\mathrm{j}$.

\subsubsection{Cálculo das distâncias genéticas utilizando o marcador SSR}

Para o marcador SSR foram calculadas as distâncias modificadas de Rogers (Goodman \& Stuber, 1983), a partir da leitura dos genótipos, no programa TFPGA vs. 1.3 (Mille, 1997) de acordo com a fórmula abaixo: 


$$
M R D_{(I)}=\left[\sum_{k=1}^{1}\left(p_{i k}-p_{j k}\right)^{k}\right]^{-1 / 2} 2 n
$$

em que:

$M_{R D_{(i, j)}}=$ distância modificada de Rogers,

$p_{i k}$ e $p_{j k}=$ fequencias do $k$-ésimo alelo para as linhagens $i$ e $j$, respectivamente, $\mathrm{n}=$ número de locos;

$I=$ número total de alelos considerando todos os locos.

\subsubsection{Agrupamentos das linhagens e análises de coordenadas principais}

As distâncias genéticas de cada marcador, AFLP e SSR, foram utilizadas para fazer os agrupamentos das linhagens pelo método UPGMA (unweighted pair-group method averages) e a dispersão gráfica dos dados foi feita pelo método de coordenadas principais (PCO, Gower, 1996) com o programa NTSYS-pc versão 2.0 (Rohlf, 1997). Para cada dendrograma foi calculado o valor de correlação cofenética entre a matriz de distâncias genéticas e a matriz dos valores cofenéticos.

\subsubsection{Correlações entre os marcadores}

As correlações entre as distâncias dos marcadores foram feitas utilizando o teste de Mantel (1967). O teste de aleatorização de Mantel associa elementos de duas matrizes fazendo a correlação (correlação dos produtos dos momentos, r) entre seus elementos correspondentes. A significância dessa correlação é determinada pela comparação das distribuições das correlações encontradas a partir da aleatorização dos elementos de uma das matrizes. Dessa forma a correlação original é comparada com as sucessivas correlações 
obtidas de matrizes com elementos aleatorizados ao acaso dentro de cada uma delas. A matriz original é chamada de matriz $M$, a matriz a ser aleatorizada é chamada de matriz $E$ é a matriz $E$ aleatorizada é chamada de $E_{R}$. A correlação é feita entre $M$ e $E$, gerando um valor $Z$, e entre $M$ e as matrizes $E_{R s,}$ produzindo-se uma distribuição aleatorizada de $Z$. Observa-se então se o valor original de $Z$ é um valor da distribuição aleatorizada de $Z$. Tem-se assim que:

$$
Z=\sum_{1, j}^{n} x_{i j} y_{i j}
$$

em que:

$Z$ = valor da estatística de Mantel,

$X_{\mathrm{ij}}$ e $Y_{\mathrm{ij}}=$ elementos da matriz $\mathrm{MeE}$, com exceção dos elementos da diagonal.

$O$ teste assume que as duas matrizes foram obtidas independentemente. Se as duas matrizes são correlacionadas, então Z pode ter um valor tão grande quanto aos obtidos pelas correlações entre a matrizes $\mathrm{M} \mathrm{e}$ a matriz casualizada $E_{r}$.

Nesse trabalho foram correlacionadas duas matrizes de distâncias obtidas com os marcadores AFLP e SSR, utilizando-se 9999 permutações.

\subsubsection{Análise bootstrap dos marcadores AFLP e SSR}

O método de reamostragem foi utilizado para verificar se o número de bandas polimórficas do marcador AFLP e o número de locos (combinação de "primers") do marcador SSR foi suficiente para determinar com precisão as estimativas de distâncias genéticas entre as linhagens. Seguiu-se para tanto o esquema proposto por Tivang et al. (1994).

O marcador AFLP foi utilizado para essas análises na forma de matriz binária. Para cada par de linhagens, a distância genética foi estimada 
utilizando-se o coeficiente de Jaccard a partir de reamostragem de bandas ao acaso, com amostras de diferentes tamanhos $(24,74,124,174,224,274,324$, $374,424,474,524,574,624,674,724$ e 774). Para cada tamanho da amostra, foram feitas 500 reamostragens. Dessa forma, foi possivel calcular uma média e uma variância e o coeficiente de variação, como medida de precisão, para cada tamanho de amostra.

O marcador SSR foi análisado na forma de locos (pares de primers). Para cada par de linhagens a distância genética foi estimada com o coeficiente de Rogers modificado, a partir de reamostragens de diferentes tamanhos $(8,14$, $20,26,32,38,44,50,56,62,68)$. O procedimento para o cálculo do coeficiente de variação foi menor que o utilizado para o AFLP.

Essas análises foram realizadas utilizando-se o procedimento PROC INL do programa computacional SAS.

\subsection{Correlações entre as distâncias genéticas e as médias de heteroses da produção de grãos.}

As correlações entre os dados de produção de grãos e heteroses dos híbridos $F_{1}$ e as distâncias genéticas foram feitas pela correlação linear de Pearson, de acordo com Falconer (1981).

$$
r=\frac{\operatorname{cov}_{x y}}{\sqrt{\operatorname{var}_{x}} \sqrt{\operatorname{var}_{y}}}
$$

em que:

$\mathrm{X}$ e $\mathrm{Y}$ são as duas características em questão,

$r=$ correlação linear de Pearson,

$\operatorname{cov} x y=$ covariância entre as duas características $x$ e $y$,

$\operatorname{var}_{\mathrm{X}}=$ variância da característica $\mathrm{x}$, 
$\operatorname{var}_{y}=$ variância da característica $y$.

A heterose foi obtida pela diferença entre o híbrido $F_{1}$ e a média dos genitores para os dados de produção de grãos (Lanza et al., 1997). Quatro cruzamentos resultantes de combinações com a linhagem BR106-16 (16 x 09, $16 \times 10,16 \times 13,16 \times 15$ ) não foram utilizados nas análises (dados perdidos no campo). Devido ao alto grau de parentesco das linhagens irmãs, com valor de heterose negativa, o cruzamento entre elas (BR106-11e BR106-12) foi descartado nas análises de correlação linear. 


\section{RESULTADOS E DISCUSSÃO}

\subsection{Otimização do protocolo de amplificação dos locos AFLP}

Inicialmente foram avaliadas três diferentes quantidades de DNA para realização das digestões: $200 \mathrm{ng}$, 300ng e 400ng de DNA. Os resultados não mostraram diferenças sensíveis, tendo-se optado pela quantidade intermediária de 300ng na reação de digestão e posterior aumento (duplicação) na concentração de DNA utilizado como molde para a amplificação seletiva.

Uma vez estabelecida a concentração de DNA, efetuou-se a reação de marcação do "primer" com $\gamma$ ATP e $P^{32}$ ou $P^{33}$. Observou-se que a definição das bandas marcadas $\gamma$ ATP e $P^{33}$ foi excelente, muito melhor que a marcação do "primer" feita com $\gamma$ ATP e $\mathrm{P}^{32}$. Embora o $\gamma \mathrm{ATP}$ marcado com $\gamma \mathrm{P}^{33}$ seja bem mais caro e seja necessário esperar até três dias para obtenção de uma intensidade das bandas satisfatória na autorradiografia, a sua utilização é imprescindível para a utilização deste tipo de marcador. Todas as outras variáveis das reações de digestão, pré-amplificação, marcação e amplificação seletiva foram mantidas conforme o especificado pelo protocolo.

As reações de amplificação foram efetuadas em dois termocicladores com e sem tampa aquecida, ou seja, realização das reações de amplificação recobertas ou não com óleo mineral e uso de três aparelhos de eletroforese vertical de diferentes tamanhos, para se determinar qual deles fornecia a melhor resolução. Os resultados mostraram que não há nenhuma variação no perfil de bandas obtidas na reação de AFLP efetuada em termociclador com ou sem tampa aquecida. Este resultado é muito importante, pois além de 
flexibilizar a sua realização, sendo possível a utilização de qualquer dos termocicladores, mostra que a técnica é altamente reproduzível.

Como se desconhecia a relação entre o tamanho da placa vertical e a melhor separação das bandas de AFLP para milho, efetuou-se a eletroforese em placas com 60, 45 e $30 \mathrm{~cm}$. Como era de se esperar, os melhores resultados, com relação a separação e nitidez das bandas, foram obtidos com a placa de $60 \mathrm{~cm}$. Para otimização das condições de migração foram analisados diferentes tempos e temperaturas de migração do gel de poliacrilamida, bem como a concentração de poliacrilamida. Ficaram definidas as seguintes condições, para um gel de $45 \mathrm{~cm}$ de comprimento: gel a $6 \%$ de poliacrilamida, eletroforese a $1800 \mathrm{v}, 75 \mathrm{~W}$ (constante), $50 \mathrm{~mA}, 45^{\circ} \mathrm{C}$ e tempo aproximado de corrida de 4 horas. Para o gel de $60 \mathrm{~cm}$ : gel poliacrilamida $6 \%$, eletroforese a $2000 \mathrm{v}, 25 \mathrm{~W}, 25 \mathrm{~mA}$, sem controle de temperatura e tempo de corrida de 2:30 horas. A eletroforese foi feita nas duas placas para cada combinação de "primer" testadas em todas as amostras, de forma que cada marcação foi obtida em duplicata.

Os resultados obtidos nos dois géis indicaram a alta repetibilidade do AFLP, expresso em intensidade e separação entre bandas. A repetibilidade do marcador AFLP foi avaliado pela amplificação em diferentes máquinas e aparelhos de eletroforese. O padrão de bandas se manteve invariável independentemente da máquina de PCR utilizada e aparelho de eletroforese. Similarmente, estudos de repetibilidade com AFLP foram desenvolvidos e confirmados em diferentes laboratórios na Europa (Jones et al., 1997) utilizando clones de beterraba. Esses resultados não revelaram qualquer diferença nos perfis de AFLP para todos os testes avaliados. Na Figura 1 encontra-se a amplificação das 18 linhagens com o par de "primers" EAAG/ MCTG, como ilustração. 


\subsection{Otimização do protocolo de amplificação dos locos SSRs}

Para o marcador SSR foram ajustados 80 "primers", sendo 68 polimórficos. Desses 68 "primers", 53 cobriram "bins" diferentes, distribuídos nos 10 cromossomos de milho, 14 cobriram "bins" repetidos e um não apresentou localização precisa. Os 68 "primers" SSRs detectaram um total de 200 alelos, com uma variação de dois a cinco alelos por loco (Tabela 3). Na Figura 2 observa-se que as amplificações dos alelos com o "primer" PHI 052 ficaram bem definidos no gel, porém a maioria das amplificações microssatélites detectou apenas dois alelos.

Foi obtida uma baixa variabilidade nos locos microssatélites. O número total de alelos pode ter sido subestimado desde que diferenças pequenas em torno de dois pares de base não tenham sido detectadas em gel de agarose/methaphor. É possivel a detecção de alelos adicionais pelo uso de géis de poliacrilamida denaturante, possibilitando a resolução de novos alelos (Morgante, 1994). A alta resolução dos géis de poliacrilamida utilizados nas análises com marcadores permite uma maior precisão na identificação de alelos e dessa forma uma estimativa mais precisa de distância genética entre as linhagens. Isso pode eventualmente levar a uma maior predição da performance de híbridos.

\subsection{Niveis de polimorfismos obtidos com AFLP e SSR}

As 18 linhagens foram avaliadas com dois sistemas marcadores diferentes: AFLP e SSR. Na tabela 3 estão discriminados os 68 "primers" microssatélites usados na avaliação das linhagens de milho. $O$ número de alelos obtidos com as diferentes combinações de "primers" variou de 2 a 5 . 0 maior número de alelos foi observado com os "primers" BMC1006, MACEOOB03, BNLG 244 e MACT02B10. Dos 68 "primers" utilizados, 28 amplificaram dois alelos, 20 três alelos e, 16 quatro. 
1 18

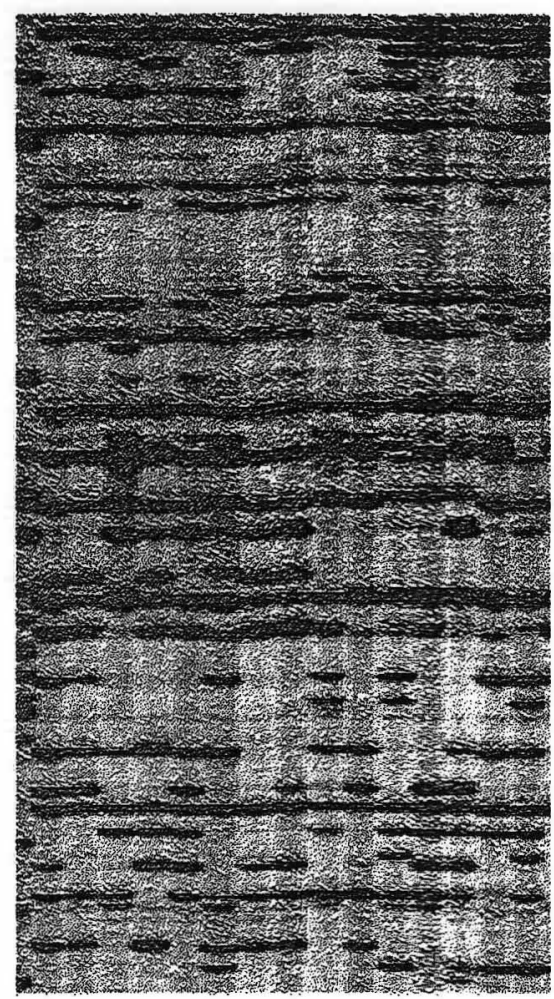

Figura 1 - Amplificações AFLP das 18 linhagens de milho pertencentes à população BR105 (01 a 08) e BR106 (09 a 18) com a combinação de "primers" EAAG/MCTG.
$-18$

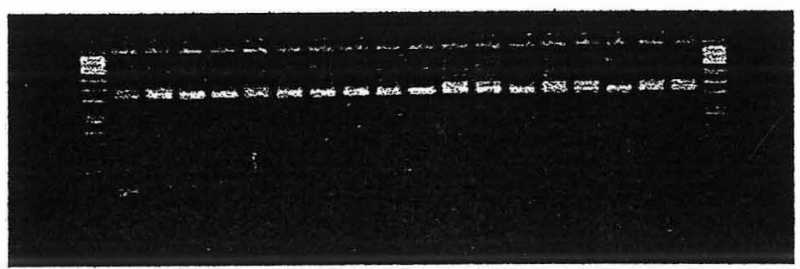

Figura 2 - Amplificaçōes microssatélites com o "primer" PHI-052 em 18 linhagens de milho pertencentes à população BR-105 (01 a 08) e BR-106 (09 a 18).

$\mathrm{Na}$ Tabela 4 encontra-se $\mathrm{o}$ número de bandas monomórficas e polimórficas (totais e dentro de cada população), obtidas nas amplificações com o marcador AFLP. Os números de fragmentos polimórficos, amplificados para cada par de "primers" nas 18 linhagens foram bastante variados. As vinte combinações de "primers" analisadas geraram 1100 fragmentos, sendo 774 polimórficos e 326 monomórficos. O número de fragmentos totais amplificados variou de 22 (E-AAG/M-CAG) a 81 (E-AAG/M-CTG) com uma média de 55 fragmentos por "primer". Dos 774 fragmentos polimórficos, 488 foram amplificados nas duas populações, 110 exclusivamente na BR-105 e 176 exclusivamente na BR-106. O "primer" E-AAC/M-CTC apresentou o maior 
número de fragmentos amplificados, comuns às duas populações. $O$ "primer" com menor número de fragmentos amplificados foi o E-AAG/M-CAG.

Os niveis de polimorfismos detectados para cada marcador e a comparação de suas capacidades informativas estão apresentados na Tabela 5. O número de análises variou de 20 combinações de "primers" para AFLP a 68 combinações de "primers" microssatélites para SSR. O número de bandas polimórficas identificadas foi 774 para AFLP e 200 para SSR. No marcador AFLP, considerou-se cada banda dentro das linhagens como um loco. No marcador SSR um loco corresponde às bandas pertencentes a cada combinação de "primers". Foi calculada a média de bandas, dividindo-se o total de alelos observados em todos os locos pelo número de locos. O AFLP apresentou 2 alelos por loco. O marcador SSR que apresentou uma média de 2,94 por loco com variação de 2 a 5 alelos por combinação de "primer".

O AFLP foi capaz de detectar um grande número de bandas em cada reação, com média de 38,7 o que eqüivale a aproximadamente 13 vezes mais que os detectados com microssatélites. Uma das vantagens do AFLP é o grande número de fragmentos detectados com um número relativamente pequeno de "primers". Dos fragmentos polimórficos encontrados, 63,05\% estiveram presentes em linhagens das duas populações, indicando o alto grau de similaridade a nível de DNA entre elas. Foram detectados 774 fragmentos polimórficos com 20 combinações de "primers" em contraposição ao SSR com 200 fragmentos obtidos com 68 pares de "primers". Em particular, para o AFLP a maior eficiência em números de locos é devido à detecção simultânea de muitas bandas polimórficas em uma reação multiplex por reação.

\subsection{Distâncias genéticas obtidas com os dois marcadores}

As distâncias genéticas obtidas com os marcadores AFLP e microssatélites encontram-se nas Tabelas 6 e 7, respectivamente. 
A matriz de distâncias genéticas gerada com as 774 bandas do marcador AFLP apresentou valores numa amplitude de variação de 0,085 a 0,701. A maior distância foi obtida entre as linhagens BR105-08 x BR106-12, a nivel interpopulacional, e a menor entre as linhagens BR106-11 x BR106-12, que são linhagens irmãs. Os híbridos interpopulacionais apresentaram distâncias variando de 0,518 a 0,701 . Os menores valores em distâncias foram exibidos por dez dos 45 híbridos intrapopulacionais da BR106 (entre todas as combinações das linhagens 11,12 e 14, dessas com as linhagens 17 e 18 e das duas últimas entre si) e na combinação das linhagens 06 com 07 da população BR105.

A matriz de distâncias genéticas gerada com os locos microssatélites apresentou uma amplitude de variação semelhante à observada com o marcador AFLP $(0,165$ a 0,765$)$. Os hibridos interpopulacionais apresentaram amplitude de variação de 0,536 a 0,756. A maior distância foi observada entre as linhagens BR106-16 e BR106-18 e a menor entre as linhagens irmãs BR10611 e BR106-12, ambas, a nivel intrapopulacional. Embora a combinação de linhagens com o maior valor de distância não tenha coincidido nos dois marcadores, todas as combinações que exibiram valores altos de distância com o marcador AFLP também tiveram valores altos com SSR. Nos cruzamentos entre linhagens menos aparentadas, como as observadas nos hibridos interpopulacionais e alguns intrapopulacionais, os dois marcadores se mostraram equivalentes.

A correlação entre as distâncias genéticas estimadas com os dois marcadores foi de 0,78. Embora o marcador AFLP apresente distribuição ao acaso e os microssatélites tenham sido selecionados para serem distribuídos em todo o genoma, os dois marcadores apresentaram um alto coeficiente de correlação, indicando que as duas classes de marcadores amostraram uma grande parte do genoma em comum; porém, as diferentes partes amostradas por cada marcador foram importantes na discriminação das linhagens com alto grau de parentesco. As estimativas de distâncias genéticas podem ter sido 
afetadas pelo fato de cada matriz de distância ter sido computada a partir de diferentes números de locos.

Um resumo das estimativas das distâncias genéticas, calculadas para cada marcador entre os pares de linhagens dos dois grupos heteróticos, está apresentado nas Tabelas 8 e 9. Os valores médios de distâncias genéticas estimadas com o marcador SSR foram superiores aos estimados com o marcador AFLP. Os desvios padrão das diferentes combinações de linhagens nos dois marcadores são semelhantes aos observados com RFLP e RAPD com essas mesmas linhagens (Benchimol et al., 2000, Lanza et al., 1997) e com AFLP em outras linhagens de milho (Ajmone Marsan et al., 1998). Os dois marcadores indicaram que as linhagens originadas da BR105 foram mais similares do que as da BR106. Nos híbridos intrapopulacionais da população BR106, a amplitude de variação das distâncias genéticas foi mais elevada do que na população BR105. O valor médio das distâncias genéticas interpopulacionais foi um pouco maior do que os dos híbridos intrapopulacionais, porém a amplitude de variação dos híbridos intrapopulacionais foi maior do que nos interpopulacionais. Isto é consistente com o fato de que em melhoramento de milho o desenvolvimento de híbridos é preferencialmente desenvolvido pelo cruzamento de linhagens entre grupos heteróticos.

As médias das distâncias genéticas dos híbridos obtidas com 0 marcador AFLP, a nível intrapopulacional (BR-105 e BR-106) e de cada população individualmente, foram semelhantes. Quando estimadas com 0 marcador SSR essas médias diferiram, sendo ligeiramente superiores na BR106. Os valores médios das distâncias genéticas demonstraram que linhagens do mesmo grupo heterótico são geneticamente mais similares que aquelas originadas de diferentes grupos heteróticos.

Esses resultados foram semelhantes aos obtidos com distâncias genéticas calculadas a partir de marcadores RFLP (Benchimol et., 2000, Boppenmaier et al., 1992, 1993, Lee et al., 1989, Melchinger et al., 1992), 
RAPD (Lanza et al., 1997), AFLP e RAPD (Wu, 2000) e RFLP e AFLP (AjmoneMarsan et al., 1998). Segundo Melchinger, (1999) independente do sistema marcador e do material sob investigação, combinações de genótipos de diferentes grupos de germoplasma tem uma distância genética média maior do que combinações de genótipos do mesmo grupo. Devido à extensa amplitude de variação dos valores das distâncias para combinações dentro de grupos de germoplasmas e a diferença relativamente pequenas entre grupos, Melchinger et al. (1991) concluíram que, para uma classificação confiável de linhagens de origens desconhecidas para determinação de grupos heteróticos através de distâncias genéticas, é necessário um número relativamente alto de representantes de cada grupo.

\subsection{Análise de agrupamento do AFLP e SSR}

Os dendrogramas obtidos pelo método UPGMA, das distâncias genéticas baseadas em AFLP e SSR, encontram-se nas Figuras 3 e 4 . Ambos tem um alto valor cofenético $(r=0,94$ e $r=0,88$ para AFLP e SSR, respectivamente) refletindo uma boa concordância com os valores de distância. No dendrograma, com poucas exceções, as linhagens foram alocadas a seus respectivos grupos heteróticos (previamente definidos) ou se não, ficaram agrupadas bem próximas como é o caso das linhagens analisadas com SSR. O agrupamento gerado a partir da matriz de distâncias com o marcador AFLP foi consistente com os padrões heteróticos previamente definidos, com exceção da linhagem BR106-16 que se agrupou com as linhagens da população BR105. Esses resultados, utilizando dados de AFLP, são próximos aos relatados com RFLP e com essas mesmas linhagens (Benchimol et al., 2000). Outros estudos com milho e marcadores moleculares também conseguiram alocar linhagens de acordo com seus grupos heteróticos (Lee et al., 1989; Melchinger et al., 1991, Ajmone-Marsan et al., 1995, Messmer et al., 1992, Mum e Dudley, 1994). 
De forma geral, para o AFLP, as duas populações se dividiram em dois grupos distintos. Assim, um grupo ficou composto pelas linhagens da população BR105 e pela linhagem 16 da BR-106, e o outro pelas demais linhagens da população BR106. O primeiro grupo, formado pelas linhagens da BR-105, dividiu-se em quatro subgrupos, sendo o primeiro composto pelas linhagens $01,02,05$ e 04, o segundo pelas linhagens 06 e 07, o terceiro pela linhagem 16 (população BR-106) e o último pelas linhagens 03 e 08 . O segundo grupo, formado somente pelas linhagens da BR106, dividiu-se em três subgrupos: o primeiro subgrupo ficou formado pelas linhagens $11,12,17,18$, 14 e 15 , o segundo pelas linhagens 09 e 10 e o terceiro, somente pela linhagem 13.

Comparando-se os grupos formados a partir das distâncias genéticas do marcador AFLP com aqueles formados a partir das distâncias estimadas com o marcador SSR, verifica-se que estes apresentaram algumas diferenças. Os resultados obtidos com o SSR, ao contrário do AFLP, foram mais discordantes em relação ao estabelecimento prévio da divisão de grupos heteróticos baseados na genealogia (Naspolini $F^{\circ}$ et al., 1981). Nos agrupamentos obtidos com as distâncias estimadas com os dados do marcador SSR foram observados os seguintes grupos: o primeiro, formado pelas linhagens 01, 02, 03, 04, 05, 06, 07 e 08 da BR105 e pelas linhagens 09, 10 e 16 da BR-106; o segundo pelas linhagens $11,12,14,15,17$ e 18, da população BR106 e o terceiro pela linhagem 13 da população BR106. Os subgrupos obtidos com o marcador SSR foram semelhantes aos obtidos com o marcador AFLP. Um subgrupo formado pelas linhagens $11,12,14,15,17$ e 18, da BR106 foi semelhante ao obtido com o marcador AFLP. Os subgrupos formados pelas linhagens 02 e 05, 03 e 08 e 06 e 07 da BR105, obtidos com o marcador AFLP, também foram observados com o marcador SSR. A linhagem 13, que havia formado um único subgrupo dentro da BR106 com o marcador AFLP, continuou sozinha com o marcador SSR. A linhagem 16 da população BR-106, nos agrupamento obtidos com as distâncias estimadas com os dois 
marcadores, permaneceu junto às linhagens da BR105. Apesar das linhagens de cada população não terem formado grupos bem definidos, as linhagens da população BR105, assim como da BR106, se agruparam bem próximas, com exceção da linhagem BR106-09 que ficou bem distante das linhagens da sua população. Subgrupos formados pelas linhagens 03 e $08 ; 06$ e 07; 11, 12, 14, 17 e 18; ou 11, 14, 15, 17 e 18, com essas mesmas populações, foram observados em estudos com RFLP (Benchimol et al., 2000) e RAPD (Lanza et al., 1997), respectivamente.

A análise de coordenadas principais a partir das distâncias genéticas obtidas com o marcador AFLP também apresentou a mesma disposição das linhagens agrupadas no dendrograma (Figura 5). No gráfico bidimensional a visualização dos subgrupos é bem clara. O agrupamento gerado dentro da população BR106 confirmou a sua grande variabilidade devido principalmente aos subgrupos formados, que são relativamente divergentes. Dentro da população BR105, a variabilidade existente é devido às linhagens, porém com uma amplitude de variação menor. Os subgrupos da BR105 também ficaram bem evidentes na dispersão gráfica das linhagens. As três primeiras coordenadas principais explicaram $36,26 \%$ da variância total, mas mesmo assim refletiram o mesmo padrão de agrupamento observado no dendrograma. No caso em que somente uma pequena parte da variação total é explicada pela análise de coordenadas principais, Livini et al. (1992), recomendam o uso do agrupamento e a análise de coordenadas principais, conjuntamente, para se obter o máximo de informações dos dados. Dessa forma, os dois critérios foram eficientes para agrupar as linhagens.

Quando se observa a dispersão gráfica das linhagens obtidas a partir das distâncias com o marcador SSR (Figura 6), nota-se a mesma tendência observada com o marcador AFLP, isto é a manutenção dos subgrupos dentro de cada população. Porém os agrupamentos obtidos com o marcador AFLP são mais nítidos. Com o marcador SSR a dispersão das linhagens da população BR106 foi maior do que a observada com na população BR105, as quais 
permanecem mais próximas. As linhagens 09, 10 e 16 da população BR-106 continuam agrupadas com a população BR105, conforme verificado no dendrograma. Os três primeiros eixos principais explicaram $42,89 \%$ da variação total.

\subsection{Análise do número de locos}

Para determinar o coeficiente de variação das distâncias genéticas calculadas com os dois marcadores (AFLP e SSR), a análise bootstrap foi feita com o aumento progressivo e com intervalos constantes do número de locos adicionais amostradas nos dois marcadores. Para cada marcador, as análises estão representadas nas Figuras 7 e 8.

Esses resultados indicam que em torno de 374 bandas, do marcador AFLP, foram suficientes para se obter com precisão as estimativas das distâncias genéticas (CV entre 5 e 10\%). A partir daí há uma tendência a estabilidade na precisão, com o aumento de bandas. Logo, conclui-se que o número de bandas usadas no presente trabalho foi suficiente.

Com o marcador SSR o coeficiente de variação atingiu entre 5 e $28 \%$ (mínimo e máximo) com o número máximo de locos avaliados (68), indicando a necessidade do aumento do número de locos para o aumento da precisão das estimativas das distâncias genéticas ou o aumento na precisão da detecção de alelos dentro de cada loco. Porém, o que pode ter causado a baixa detecção do número de locos obtidos com os 68 pares de "primers" tenha sido a menor precisão do gel agarose:methafor na detecção de locos com diferenças em motivos compostos com poucos pares de bases. A discrepância no agrupamento das linhagens obtidos com os dados SSR em comparação com os dados de AFLP pode ser devida a menor precisão dos dados de SSR. Pejic et al. (1998) avaliando 33 linhagens endogâmicas de milho com RFLP, RAPD, AFLP e SSR, determinou que 30-40 combinações sondas-enzimas de RFLP, 40-50 "primers" RAPD, 4-5 combinações de "primers" de AFLP e 20-30 
"primers" SSR foram suficientes para determinar com precisão as estimativas de distâncias genéticas entre as linhagens.

Nesse estudo, o AFLP forneceu informações mais consistentes com as informações prévias dos grupos heteróticos. Porém, segundo Pejic et al. (1988) tanto o marcador AFLP como o SSR são bons candidatos para substituir o marcador RFLP em estimativas de similaridades genéticas. Isso ocorre devido ao multialelismo e codominância do SSR e a alta razão multiplex do AFLP, sendo o primeiro útil na análises de indivíduos heterozigotos, e o último quando a cobertura do genoma é necessária devido ao desequilíbrio de ligação em linhagens endogâmicas e materiais melhorados.

\subsection{Performance de hibridos e distâncias genéticas entre as linhagens com os dois marcadores.}

As estimativas das médias, desvios padrão e amplitudes de variação para produção de grãos e heterose encontram-se na Tabela 10. Para a produção de grãos e heterose, os híbridos interpopulacionais apresentaram a maior média. Porém a amplitude de variação foi maior entre os híbridos intrapopulacionais da BR106, os quais apresentaram a menor produção de grãos e heterose. Os híbridos intrapopulacionais da BR105 apresentaram uma média de produção de grãos maior que os híbridos intrapopulacionais da BR106. A heterose média dos híbridos da BR105 foi a segunda maior entre todas as combinações, mas com a menor amplitude de variação.

As distâncias genéticas estimadas com os marcadores AFLP e SSR, para produção de grãos e heterose para cada combinação de linhagens entre e dentro de cada população encontram-se nas Tabelas 11, 12 e 13. Altas produções de grãos, heterose e distâncias genéticas foram obtidas entre e dentro das duas populações. Exceções foram encontradas nas combinações interpopulacionais BR106-16 com BR105-03 ou com BR105-04, onde valores 
relativamente altos e médianos de distâncias, obtidas com AFLP e SSR, estiveram associados com valores de baixa produção e de heterose.

Na população BR105, assim como na população BR106, os híbridos com maiores e as menores distâncias genéticas também apresentaram os maiores e menores valores de produção de grãos ou heterose, respectivamente, na maioria dos casos.

Os híbridos da população BR105 com os menores valores de distâncias genéticas e os menores valores de produção e heterose foram $06 \mathrm{x}$ 07 e $03 \times 08$. Nos cruzamentos obtidos de linhagens da população BR106 observou-se que as distâncias mais baixas referem-se aos cruzamentos de baixa produção e heterose $(11 \times 14,11 \times 17,11 \times 18,12 \times 14,12 \times 17$ e $12 \times$ $18,14 \times 17$ e $14 \times 18$ e $17 \times 18$ ). Vale ressaltar que as linhagens 11 e 12 são linhagens irmãs e as distâncias genéticas, produções de grãos e heteroses, resultantes de suas combinações hibridas, foram as menores observadas entre todos os cruzamentos. Todas as linhagens envolvidas nessa combinação ficaram no mesmo subgrupo, independentemente dos marcadores. Como pode se observar, nas combinações dessas linhagens mais aparentadas é onde foram obtidos as mais baixos valores de distâncias, produção e heterose. Esses resultados indicam que as distâncias genéticas obtidas com os marcadores AFLP e SSR, refletem o potencial dos híbridos.

Os coeficientes de correlação entre as performances de híbridos e heteroses com as distâncias genéticas estimadas com os marcadores AFLP e SSR, encontram-se nas Tabelas 14 e 15. Foram considerados para análises de correlação os híbridos intrapopulacionais de cada população (BR105 e BR106), os híbridos interpopulacionais e todos os híbridos conjuntamente. Os coeficientes de correlação entre as distâncias genéticas estimadas com o marcador AFLP e a produção de grãos e a heterose para produção (Tabela 14) foram altos e significativos, considerando-se todos os híbridos e os intrapopulacionais da população BR106 $(r=0,70)$. Na população BR105, as 
correlações foram significativas e de valor moderado $(r=0,50)$. Nos híbridos interpopulacionais, não foram encontradas correlaçōes significativas.

Similarmente aos resultados de correlações com AFLP, foram observadas correlações significativas entre a produção de grãos e heterose para produção com distâncias genéticas estimadas com o marcador SSR (Tabela 15). Nos híbridos intrapopulacionais da BR106 os coeficientes foram altos e significativos $(r=0,70)$ e de valor médio para todos os híbridos e para os híbridos da BR105 $(r=0,50)$. Na população BR105 foram encontradas correlações significativas somente para a produção de grãos. Nos híbridos interpopulacionais não foram encontradas correlações significativas.

Os maiores valores em correlações foram observadas entre distâncias genéticas e performances de híbridos e heteroses estimadas com AFLP em comparação com as estimadas com SSRs. Isso provavelmente é devido ao maior número de locos AFLP marcados em comparação com os locos de SSRs, utilizados nessas análises, conforme revelou a análise bootstrap. Segundo Tivang et al., 1994, a precisão das estimativas aumenta quando um maior número de sondas ou locos marcadores são usadas nas análises. $O$ AFLP forneceu uma maior cobertura do genoma, o que permite a sua utilização com mais precisão nas estimativas das distâncias genéticas.

As distâncias genéticas baseadas em AFLP são portanto eficientes para alocar os genótipos obtidos de populações de milho tropical em seus grupos heteróticos. Entretanto, distâncias genéticas baseadas em AFLP e SSR não foram úteis para identificar os melhores cruzamentos a nível interpopulacional, de maneira similar a outros resultados já publicados (Frei et al., 1986; Lee et al. 1989; Godshalk et al., 1990; Melchinger, 1999). Esses resultados concordam com os obtidos com RFLP e RAPD, com essas mesmas linhagens, onde as correlações considerando os grupos heteróticos identificados previamente foram muito baixas (Lanza et al., 1997; Benchimol et al., 2000). Correlações entre distâncias genéticas baseadas em AFLP e RFLP, produção de grãos dos híbridos $F_{1}$ e heteroses para produção de grãos em 
linhagens endogâmicas de milho foram de baixo valor preditivo, porém foram significativa entre capacidade especifica de combinação e distância genética especifica baseada em AFLP (Ajmone Marsan et al., 1998).

As razões para a baixa correlação entre distâncias genéticas e performances de híbridos são: as marcas não se distribuíram por todo o genoma dos individuos avaliados e a heterose para produção não está relacionada com os graus de heterozigosidade nos locos associados ao QTL para produção de grãos. (Melchinger et al., 1990b); os genes que controlam o caráter em questão não foi acessado pelas marcas usadas pare a estimativa de distância genética (Melchinger et al., 1990a, Bernardo, 1992). Segundo AjmoneMarsan et al. (1995), quando há ligação entre as marcas e os genes que controlam o caráter, algumas regiões cromossômicas, onde se encontram os genes, podem ser mais importantes do que outras em sua contribuição para a performance de produção da $F_{1}$ e heterose, e então, o mapeamento de QTLs que afetam a produção de grãos e características relacionadas podem confirmar a magnitude dos efeitos genéticos de qualquer QTL individualmente, que pode variar de 5 a $25 \%$ da variância fenotípica.

As dispersões de todos os híbridos, dos híbridos interpopulacionais e intrapopulacionais (BR105 e BR106) foram feitas para avaliar se a correlação é devido a efeito de grupos. Os gráficos de distâncias genéticas com produção de grãos e heteroses dos cruzamentos intrapopulacionais, interpopulacionais e de todos os híbridos estão representados nas Figuras 9 a 24. Os quadrantes foram divididos com as médias das distâncias genéticas e performances dos híbridos ou heteroses ao longo dos eixos $X$ e $Y$, respectivamente. Os números mostram os cruzamentos localizados nos respectivos quadrantes. Os gráficos de dispersão dos 148 híbridos, de produção de grãos vs. distância genética com os marcadores AFLP e SSR, (Figuras 9 e 10), mostraram que a maioria dos cruzamentos encontra-se acima da média de produção e de distância genética e também abaixo das duas médias, principalmente quando a distância é 
estimada com AFLP. O mesmo padrão de dispersão é observado nos gráficos de distâncias genéticas vs. heterose (Figuras 11 e 12).

Nas Figuras 13, 14, 15 e 16, encontram-se os gráficos de dispersão dos híbridos interpopulacionais, com distancias genéticas estimadas com AFLP ou SSR para produção de grãos e heterose. Nos cruzamentos interpopulacionais a distribuição dos híbridos entre os quatro quadrantes foi mais uniforme, embora um número maior de cruzamentos tenha se alocado no quadrante superior direito e inferior esquerdo, principalmente com os dados de produção de grãos ou heterose vs. distância genética estimada com AFLP. Os híbridos se dispersaram em torno do ponto de interseção das médias para as distâncias genéticas estimadas com SSR, indicando ausência de correlação.

$\mathrm{Na}$ Tabela 11 observa- se que as oscilações dos valores de distâncias genéticas dos marcadores AFLP correspondem aos do SSR, de performances de híbridos e heteroses, exceto os cruzamentos da linhagem BR106-16 com BR105-03 e BR105-04 onde distâncias relativamente altas estiveram associadas com valores baixos de produção de grãos e heterose. Porém a correlação entre distância e performance de híbridos ou heterose não foi muito alta (Tabela 14 e 15). Como a extensão em variação de distâncias genéticas, produção de grãos e heteroses foram limitadas nos cruzamentos, provavelmente a avaliação de um número maior de cruzamentos com uma maior extensão de valores para essas características leve a uma correlação mais alta.

A dispersão dos híbridos intrapopulacionais da população BR106 encontra-se nas Figuras 17, 18, 19 e 20. A maioria dos híbridos intrapopulacionais da BR106 se alocou entre o quadrante inferior esquerdo e superior direito, concordando com a alta e significativa correlação das distâncias genéticas com performances de híbridos ou heteroses. Isto implica em uma relação de aumento de produção de grãos e heterose com o aumento em distância para aqueles cruzamentos. Porém, a alta correlação observada nos cruzamentos foi devido a efeito de grupos, possivelmente devido ao 
reduzido número de linhagens envolvidas nos cruzamentos. O uso de AFLP e SSR permitiu, então, a classificação diferencial das performances dos cruzamentos, baseados em distâncias genéticas para produção de grãos (Figuras 17 e 18) e heterose (Figuras 19 e 20).

Nos híbridos intrapopulacionais da BR106 a correlação devido a efeito de grupos ficou mais evidente nos gráficos com distâncias genéticas estimadas com AFLP (Figuras 17 e 19) do que com as distâncias estimadas com SSR (Figuras 18 e 20). Isto provavelmente é devido à maior eficácia do marcador AFLP na separação e aglomeração dos híbridos obtidos dos cruzamentos de subgrupos de linhagens mais aparentadas dessa população.

A dispersão dos híbridos da população BR105 estão nas Figuras 21, 22, 23 e 24. Nos híbridos intrapopulacionais da BR105 a dispersão dos 28 híbridos usando distâncias genéticas estimadas com AFLP ou SSR para a produção de grãos ou distâncias genéticas estimadas com AFLP para a heterose refletem a correlação mediana obtida entre essas variáveis. Parte dos híbridos apresentaram produção de grãos e distâncias genéticas acima da média. A dispersão os híbridos utilizando distâncias genéticas com SSR para a heterose foi grande e em torno da média, refletindo a falta de correlação significativa.

Apesar da alta correlação nos híbridos intrapopulacionais da BR106, uma grande dispersão foi observada para a produção de grãos e para a heterose, com os dois marcadores. Segundo Smith et al. (1990), as razões para essa dispersão são os diferentes graus de ligação do marcador com o loco heterótico cruzando todo o genoma, interação diferencial de alelos do mesmo loco, a falta de constância entre distância do marcador e QTL e as mudanças nas diferentes linhagens da correlação entre ligação do marcador e QTL. Como a predição de cruzamentos altamente produtivos não é ainda tão precisa para fins de uso rotineiro em programas de melhoramento, informações sobre QTLs e características agronômicas para a produção de grãos podem ser úteis para a melhoria de predição com o uso de marcadores moleculares. 


\subsection{CONSIDERAÇÕES FINAIS}

Os resultados do presente trabalho permitem considerar alguns fatos importantes relacionados com o agrupamento das linhagens e as correlações entre distâncias genéticas com as performances de hibridos e heteroses.

Quanto ao agrupamento, os resultados obtidos com os dois marcadores não são totalmente concordantes. Tem-se que considerar, entretanto, as naturezas diferentes dos dois marcadores, que podem afetar os resultados. Além disso, as análises bootstrap indicaram que o número de "primers" utilizados com AFLP foi acima do necessário para a obtenção de informações seguras, ao contrário ao do SSR, onde o número de locos esteve aquém do necessário. Essa pode ser uma possibilidade para as divergências entre os dois marcadores. Mesmo assim, os dois marcadores agruparam a maioria das linhagens de maneira semelhante e de acordo com o esperado com base na genealogia.

Resultados obtidos com as mesmas linhagens, mas utilizando marcadores RAPD e RFLP indicaram também muitas concordâncias (Lanza et al., 1997 e Benchimol et al., 2000), particularmente com este último, indicando realmente que esses marcadores são muito úteis para o agrupamento de linhagens nos seus respectivos grupos heteróticos. É importante lembrar que para os marcadores AFLP e RFLP o número de combinação de "primers" e de sonda-enzima, respectivamente, utilizado foi grande o suficiente para a obtenção de informações mais precisas, conforme mostram os resultados do presente trabalho e aqueles de Benchimol et al., 2000.

Assim, considerando-se os marcadores RFLP e AFLP, a grande diferença ocorreu com a linhagem 16. No primeiro caso (RFLP), esta agrupouse com as demais da população BR-106, concordando com as informações da genealogia. No segundo caso (AFLP), esta agrupou-se com as linhagens do 
outro grupo heterótico, isto é, a população BR-105, fato também observado com o marcador SSR.

Nas Tabelas 16 e 17 estão apresentados os valores médios das distâncias genéticas obtidas para cada linhagem em cruzamentos intra e interpopulacionais com o marcador AFLP para as populações. Verifica-se claramente na Tabela 17 que, ao contrário das demais, a distância média da linhagem 16 é bem maior nos cruzamentos intrapopulacionais do que nos interpopulacionais $(0,663$ e 0,559 , respectivamente), contrariando inclusive os resultados médios obtidos com todas as linhagens. Embora não esteja apresentado na tabela 17, um resultado similar foi obtido com o marcador SSR, reforçando a inclusão da linhagem 16 no grupo contrastante (BR105).

As correlações entre distâncias genéticas e dados de produção de grãos e heterose também reforçam a conclusão anterior. Na Tabela 17 observase claramente que ao contrário da tendência geral (média) e das demais linhagens individualmente, a linhagem 16 foi bem mais produtiva em cruzamentos intrapopulacionais do que nos interpopulacionais $(7,42$ e 5,80 t/ha, respectivamente). Observando-se os dados de cruzamentos individuais (Tabela 11 ), observa-se inclusive que os dois cruzamentos interpopulacionais de médias e heteroses mais baixas envolvem a linhagem $16(04 \times 16$ e $03 \times 16)$. Por outro lado, a linhagem 16 esteve presente em quatro cruzamentos com a média mais alta, nos cruzamentos intrapopulacionais da BR106 $(14 \times 16,11 \times$ $16,16 \times 17$ e $12 \times 16$, em ordem decrescente de produção de grãos), sendo que os dois primeiros $(14 \times 16$ e $11 \times 16)$ correspondem às médias $(8,45$ e 7,99 t/ha) e heteroses $(6,65$ e $6,03 \mathrm{t} / \mathrm{ha})$ mais altas entre todos os 148 cruzamentos (intra e interpopulacionais) Todos estes resultados reforçam a inclusão da linhagem 16 da população BR106 no outro grupo heterótico (população BR105), contrariando assim o que foi estabelecido com base na genealogia.

Outro fato importante a ser considerado diz respeito às magnitudes e significâncias das correlações obtidas e as relações destes com os objetivos desse tipo de trabalho. Discute-se muito na literatura a significância ou não do 
coeficiente de correlação. Dependendo da finalidade, é mais importante considerar a magnitude da correlação do que a sua significância, como é o caso desse trabalho. Assim, uma correlação de magnitude 0,10, por exemplo, pode ser significativa mas não ter importância prática. Para ser utilizada como indicadora das performances de híbridos a correlação deve ser média a alta (pelo menos 0,60 ou 0,70, por exemplo). Assim, uma correlação de 0,70 indica que $49 \%$ da variação de uma variável (produção de grãos) é explicada pela variação da outra (distância genética). Nesse caso, pode ser feita uma seleção de linhagens pelas magnitudes das distâncias entre elas, desde que esta não seja muito intensa. Nesse sentido, alguns trabalhos apresentam correlações de magnitudes próximas ou maiores que esses valores (Smith et al. 1990, 1994; Bernardo, 1994; Benchimol et al., 2000).

As correlações interpopulacionais entre distâncias genéticas e produção de grãos têm sido comumente inferiores às intrapopulacionais, fato este observado também no presente trabalho, onde as correlações intrapopulacionais foram altas para a BR106 $(0,91)$ e medianas para a BR105 $(0,52)$, enquanto que a interpopulacional (BR105 x BR106) foi mais baixa $(0,29)$, utilizando marcadores AFLP (Tabela 14). Evidentemente, diversos fatores podem ser atribuídos a esses resultados. De acordo com Charcosset \& Essioux, 1994, o desequilíbrio de ligação entre marcadores e QTLs dentro dos grupos heteróticos explicaria a maior correlação nos cruzamentos intrapopulacionais. A menor correlação dentro da BR105 poderia ser explicada pela menor variação que ocorre entre as distâncias genéticas, visto que esta população tem base genética mais estreita.

Por outro lado, deve-se que considerar ainda que estas duas populações foram desenvolvidas por processos de seleção recíproca, isto é, no desenvolvimento das linhagens foram selecionadas aquelas que apresentaram melhores performances em cruzamentos recíprocos. Se isso é verdade, estas deveriam apresentar menor variação para distâncias genéticas, fato que pode ser facilmente constatado nas Tabelas 8 e 9 , onde, os híbridos 
interpopulacionais apresentaram médias altas, mas pouca variação para distâncias genéticas, ao contrário dos intrapopulacionais. Em resumo, no processo de desenvolvimento das linhagens já houve seleção para divergência genética interpopulacional, reduzindo a variação, mas não para divergência genética intrapopulacional. Uma redução de variação causa, evidentemente, uma redução de correlação, o que explicaria os resultados obtidos neste e em outros trabalhos. 


\section{CONCLUSÕES}

Os resultados obtidos no presente trabalho permitem apontar as seguintes conclusões, relacionadas com o agrupamento de linhagens e predição de performances de híbridos:

Os marcadores AFLP e SSR podem ser utilizados para alocar linhagens de milho a grupos heteróticos, para a produção de grãos;

A linhagem 16, da população BR106, foi alocada ao grupo heterótico contrastante (BR105) pelos dois marcadores, fato este corroborado pelas médias de produção de grãos de híbridos intra e interpopulacionais;

Para a obtenção de informações seguras são necessários em torno de 400 bandas AFLP e em torno de 100 locos SSR;

Foram detectadas correlações significativas entre as distâncias genéticas das linhagens, com base em AFLP e SSR, e produção de grãos, principalmente para os híbridos intrapopulacionais, indicando que as medidas de distâncias genéticas podem ser úteis em etapas iniciais de programas de seleção de linhagens para capacidade de combinação, reduzindo os custos com a experimentação para a avaliação de cruzamentos;

Estudos adicionais devem ser conduzidos para testar um número maior de "primers" do marcador SSR, visando esclarecer alguns resultados conflitantes relacionados com alocação de algumas linhagens. 
ANEXOS 
Tabela 3. "Primers" microssatélites, suas seqüências, sua localização nos cromossomos, número de alelos detectados e as condições de amplificações de cada um deles.

\begin{tabular}{|c|c|c|c|c|c|}
\hline Primers & Sequências Flanqueadoras & Crom./bin & $\begin{array}{l}\text { Temp. } \\
\text { anel. }(\mathrm{C})\end{array}$ & $\begin{array}{c}\text { Primer } \\
\text { (mM) }\end{array}$ & $\begin{array}{l}\text { No. de } \\
\text { alelos }\end{array}$ \\
\hline \multirow[t]{2}{*}{ PHI 056} & R:ACGCCCAGATCTGTTCCTTCTC & 1.01 & $65-55$ & $0,2 \mu \mathrm{M}$ & 2 \\
\hline & F:ATGGCGGCAGGCCGATTGTT & & & & \\
\hline \multirow[t]{2}{*}{ BMC1429 } & R:CTCCTCGCAAGGATCTTCAC & 1.02 & $65-55$ & $0,2 \mu \mathrm{M}$ & 3 \\
\hline & F:AGCACCGTTTCTCGTGAGAT & & & & \\
\hline \multirow[t]{2}{*}{ BMC1016 } & R:CCGACTGACTCGAGCTAACC & 1.04 & $65-55$ & $0,2 \mu \mathrm{M}$ & 4 \\
\hline & F:CCGTAACTTCCAAGAACCGA & & & & \\
\hline \multirow[t]{2}{*}{ BNLG 615} & R:CTTCCСТCTCСССАТСТССТTTCCAA & 1.07 & $65-55$ & $0,2 \mu \mathrm{M}$ & 3 \\
\hline & F:GCAACCTGTCCATTCTCACCAGAGGATT & & & & \\
\hline \multirow[t]{2}{*}{ MACE01F06 } & R:CAGGTACTACGTGCCGTG & 1.08 & $65-55$ & $0,2 \mu \mathrm{M}$ & 3 \\
\hline & F:CTAGAGACAAACGAGGCTAGG & & & & \\
\hline \multirow[t]{2}{*}{ PHI 055} & R:GAGATCGTGTGCCCGCACC & 1.09 & $70-65$ & $0,2 \mu \mathrm{M}$ & 2 \\
\hline & F:TTCCTCCTGCTCCTCAGACGA & & & & \\
\hline \multirow[t]{2}{*}{ BMC1347 } & R:GTGGTCACGACGAAATCCTT & 1.10 & $65-55$ & $0,2 \mu \mathrm{M}$ & 4 \\
\hline & F:TTGCAATCACACAGGTGGTT & & & & \\
\hline \multirow[t]{2}{*}{ BNLG 125} & R:GAAATGGGACAGAGACAGACAAT & 2.03 & $65-55$ & $0,8 \mu \mathrm{M}$ & 4 \\
\hline & F:GGGACAAAAGAAGAAGCAGAG & & & & \\
\hline \multirow[t]{2}{*}{ PHI 083} & R:CAAACATCAGCCAGAGACAAGGAC & 2.04 & $65-55$ & $0,2 \mu \mathrm{M}$ & 2 \\
\hline & F:ATTCATCGACGCGTCACAGTCTACT & & & & \\
\hline \multirow[t]{2}{*}{ BMC1520 } & R:TCCTCTTGCTCTCCATGTCC & 2.04 & $65-55$ & $0,2 \mu \mathrm{M}$ & 4 \\
\hline & F:ACAGCTGCGTAGCTTCTTCC & & & & \\
\hline \multirow[t]{2}{*}{ BNLG 180} & R:AACGGCGGCGAGATAAAAT & 2.06 & $65-55$ & $0,2 \mu \mathrm{M}$ & 2 \\
\hline & F:CTAGAGCCTTCGTCGCAGAG & & & & \\
\hline \multirow[t]{2}{*}{ BNLG 198} & R:GCTGGAGGCCTACATTATTATCTC & 2.08 & $65-60$ & $0,8 \mu \mathrm{M}$ & 4 \\
\hline & F:GTITGGTCTTGCTGAAAAATAAAA & & & & \\
\hline \multirow[t]{2}{*}{ PHI O36 } & R:CCGTGGAGAGACGTITGACGT & 3.04 & $65-55$ & $0,2 \mu \mathrm{M}$ & 3 \\
\hline & F:TCCATCACCACTCAGAATGTCAGTGA & & & & \\
\hline \multirow[t]{2}{*}{ PHI 053} & R:CTGCCTCTCAGATTCAGAGATTGAC & 3.05 & $65-55$ & $0,2 \mu \mathrm{M}$ & 3 \\
\hline & F:AACCCAACGTACTCCGGCAG & & & & \\
\hline \multirow[t]{2}{*}{ BMC2241 } & R:GTGCACACTCTCTTGCATCG & 3.06 & $65-55$ & $0,2 \mu \mathrm{M}$ & 4 \\
\hline & F:TAGTCAGCATCTGCCGTGTC & & & & \\
\hline \multirow[t]{2}{*}{ PHI 046} & R:ATCTCGCGAACGTGTGCAGATTCT & 3.08 & $65-55$ & $0,2 \mu \mathrm{M}$ & 2 \\
\hline & F:TCGATCTITCCCGGAACTCTGAC & & & & \\
\hline \multirow[t]{2}{*}{ BMC1257 } & R: CGGACGATCTTATGCAAACA & 3.09 & $65-55$ & $0,2 \mu \mathrm{M}$ & 2 \\
\hline & F:ACGGTCTGCGACAGGATATT & & & & \\
\hline \multirow[t]{2}{*}{ PHI 047} & R:GGAGATGCTCGCACTGTTCTC & 3.09 & $65-55$ & $0,2 \mu \mathrm{M}$ & 2 \\
\hline & F:CTCCACCCTCTITGACATGGTATG & & & & \\
\hline \multirow[t]{2}{*}{ PHI 072} & R:ACCGTGCATGATTAATTTCTCCAGCCTT & 4.00 & $65-55$ & $0,2 \mu \mathrm{M}$ & 3 \\
\hline & F:GACAGCGCGCAAATGGATTGAACT & & & & \\
\hline \multirow[t]{2}{*}{ BMC1318 } & R:TTATGTGTGCAGAACGACTCG & 4.01 & $65-55$ & $0,2 \mu \mathrm{M}$ & 3 \\
\hline & F:AGCATGGCAGAGAAGGTGAT & & & & \\
\hline
\end{tabular}


Tabela 3. "Primers" microssatélites, suas seqüências, sua localização nos cromossomos, número de alelos detectados e as condições de amplificações de cada um deles.

\begin{tabular}{|c|c|c|c|c|c|}
\hline Primers & Sequências Flanqueadoras & Crom./bin & $\begin{array}{l}\text { Temp. } \\
\text { anel. }\left({ }^{\circ} \mathrm{C}\right)\end{array}$ & $\begin{array}{l}\text { Primer } \\
\text { (mM) }\end{array}$ & $\begin{array}{l}\text { No.de } \\
\text { alelos }\end{array}$ \\
\hline \multirow[t]{2}{*}{ BNLG 589} & R:GGGTCGTTTAGGGAGGCACCTTTGGT & 4.01 & $65-55$ & $0,2 \mu \mathrm{M}$ & 3 \\
\hline & F:GCGACAGACAGACAGACAAGCGCATTGT & & & & \\
\hline \multirow[t]{2}{*}{ PHI 021} & R:TTCCATTCTCGTGTTCTTGGAGTGGTCCA & 4.02 & $65-55$ & $0,2 \mu \mathrm{M}$ & 2 \\
\hline & F:CTTGATCACCTTCCTGCTGTCGCCA & & & & \\
\hline \multirow[t]{2}{*}{ PHIO79 } & R:TGGTGCTCGTTGCCAAATCTACGA & 4.04 & $65-55$ & $0,2 \mu \mathrm{M}$ & 2 \\
\hline & F:GCAGTGGTGGTTTCGAACAGACAA & & & & \\
\hline \multirow[t]{2}{*}{ BMC1755 } & R:CCTAGTAGACCTCACCGCCA & 4.05 & $65-55$ & $0,2 \mu \mathrm{M}$ & 3 \\
\hline & F:GGAGTTCACCGATGGCAC & & & & \\
\hline \multirow[t]{2}{*}{ PHI 019} & R:TCCGCCTTTGTACCAATACAAGCCA & 4.10 & $65-55$ & $0,2 \mu \mathrm{M}$ & 3 \\
\hline & F:ATCCATCTTCAGGTAGCAGGGGTA & & & & \\
\hline \multirow[t]{2}{*}{ BMC1006 } & R:GACCAGCGTGTTGATCCC & 5.00 & $65-55$ & $0,2 \mu \mathrm{M}$ & 5 \\
\hline & F:GGAGACCCCGACTCTCTCTC & & & & \\
\hline \multirow[t]{2}{*}{ MACEOOB03 } & R:TGTTCTCAACAACCACCG & 5.01 & $65-55$ & $0,2 \mu \mathrm{M}$ & 5 \\
\hline & F:CGTITAGCGATATCATIITCC & & & & \\
\hline \multirow[t]{2}{*}{ BNLG 105} & R:AGGAAAGAAGGTGACGCGCTTITC & 5.03 & $65-55$ & $0,2 \mu \mathrm{M}$ & 4 \\
\hline & F:GACCGCCCGGGACTGTAAGT & & & & \\
\hline \multirow[t]{2}{*}{ BNLG 653} & R:CGCATTGCCATGGATGAAGAACTGG & 5.04 & $70-65$ & $0,4 \mu \mathrm{M}$ & 2 \\
\hline & F:GCAAGCGCCTCACAAGGTATGCACA & & & & \\
\hline \multirow[t]{2}{*}{ BNLG 278} & R:CATGTCACGCGTTCCACTTG & 5.06 & $65-55$ & $0,2 \mu \mathrm{M}$ & 4 \\
\hline & F:CATGCATCAACGTAACTCCCT & & & & \\
\hline \multirow[t]{2}{*}{ PHI 128} & R:TTGCTCGGTATGAAGAAAATAGTCTITCC & 5.07 & $65-55$ & $0,2 \mu \mathrm{M}$ & 3 \\
\hline & F:ATCTTGCAACTAGACTGAGGCAACCA & & & & \\
\hline \multirow[t]{2}{*}{ BNLG 118} & R:CCAACAACGCGGACGTGA & 5.08 & $65-55$ & $0,2 \mu \mathrm{M}$ & 2 \\
\hline & F:CTTCCAGCCGCAACССTC & & & & \\
\hline \multirow[t]{2}{*}{ BNLG 386} & R:TGGTTIATCAGATAACGATTCAGC & 5.09 & $65-55$ & $0,2 \mu \mathrm{M}$ & 2 \\
\hline & F:CACCCTCCCTTTGCAGGTA & & & & \\
\hline \multirow[t]{2}{*}{ PHI 075} & R:GGAGGAGCTCACCGGCGCATAA & 6.00 & $70-65$ & $0,4 \mu \mathrm{M}$ & 3 \\
\hline & F:AAAGGTTACTGGACAAATATGCGTAACTCA & & & & \\
\hline \multirow[t]{2}{*}{ PHI 077} & R:GAGAAGAGGATCAGGTTCGTTCCA & 6.01 & $65-55$ & $0,2 \mu \mathrm{M}$ & 3 \\
\hline & F:CGCGTTGTACATCTTGCCTGCTT & & & & \\
\hline \multirow[t]{2}{*}{ BMC1371 } & R:TTGCCGATAAGAACCAAACA & 6.02 & $65-55$ & $0,2 \mu \mathrm{M}$ & 4 \\
\hline & F:ACGACCGGTGTGGTTACATT & & & & \\
\hline \multirow[t]{2}{*}{ UMC1014 } & R:GAAAGTCGATCGAGAGACCCTG & 6.04 & $65-55$ & $0,2 \mu \mathrm{M}$ & 4 \\
\hline & F:СССТСТСТTСАССССТTССТT & & & & \\
\hline \multirow[t]{2}{*}{ PHI 081} & R:AAGGAACTGGTGAGAGGGTCCTT & 6.05 & $70-65$ & $0,2 \mu \mathrm{M}$ & 2 \\
\hline & F:AGCCCGATGCTCGCCATCTC & & & & \\
\hline \multirow[t]{2}{*}{ PHI 070} & R:GCTGAGCGATCAGTTCATCCAG & 6.07 & $65-60$ & $0,6 \mu \mathrm{M}$ & 2 \\
\hline & F:CCATGGCAGGGTCTCTCAAG & & & & \\
\hline \multirow[t]{2}{*}{$\mathrm{BMC} 1367$} & R:CGACGGCGTACAGAGAGAG & 7.00 & $65-55$ & $0,2 \mu \mathrm{M}$ & 2 \\
\hline & $F: G G T C G C C A C C C C A C C T$ & & & & \\
\hline
\end{tabular}


Tabela 3. "Primers" microssatélites, suas seqüências, sua localização nos cromossomos, número de alelos detectados e as condições de amplificações de cada um deles.

\begin{tabular}{|c|c|c|c|c|c|}
\hline Primers & Sequências Flanqueadoras & Crom./bin & $\begin{array}{l}\text { Temp. } \\
\text { anel. }\left({ }^{\circ} \mathrm{C}\right)\end{array}$ & $\begin{array}{l}\text { Primer } \\
\text { (mM) }\end{array}$ & $\begin{array}{l}\text { No. de } \\
\text { alelos }\end{array}$ \\
\hline PHI 057 & $\begin{array}{l}\text { R:CTCATCAGTGCCGTCGTCCAT } \\
\text { F:CAGTCGCAAGAAACCGTTGCC }\end{array}$ & 7.01 & $65-55$ & $0,2 \mu \mathrm{M}$ & 2 \\
\hline BNLG 398 & $\begin{array}{l}\text { R:CGTCGGCCAACAGGGTATC } \\
\text { F:CTCGCAGCGGGTCTTCTTC }\end{array}$ & 7.02 & $65-55$ & $0,4 \mu \mathrm{M}$ & 3 \\
\hline BNLG 657 & $\begin{array}{l}\text { R:TCTGAGGATGCCCAATCATGCGC } \\
\text { F:CGTTTCCGTTCGTCACCAGCTCG }\end{array}$ & 7.02 & $65-55$ & $0,4 \mu \mathrm{M}$ & 4 \\
\hline PHI 034 & $\begin{array}{l}\text { R:NNNNNNNNNNNNNNNNNNNNNN } \\
\text { F:NNNNNNNNNNNNNNNNNNNN }\end{array}$ & 7.02 & $65-55$ & $1,0 \mu \mathrm{M}$ & 3 \\
\hline BNLG 434 & $\begin{array}{l}\text { R:GTGCAAAGGGGAGAGAGGAA } \\
\text { F:TCGCCGTTCTCGCCTTAG }\end{array}$ & 7.03 & $65-55$ & $0,4 \mu \mathrm{M}$ & 3 \\
\hline MACE01F07 & $\begin{array}{l}\text { R:TCGTTCGGTCCATGAAAT } \\
\text { F:CAAATATCTCTCATCTTTGCTGAC }\end{array}$ & 7.04 & $55-50$ & $0,6 \mu \mathrm{M}$ & 4 \\
\hline BNLG 572 & $\begin{array}{l}\text { R:ACTGGACTGTCCTCGTGCCTA } \\
\text { F:CAAAAAAAGATTCGTTCGGAGTAA }\end{array}$ & $7.04 / 7.06$ & $65-60$ & $0,4 \mu \mathrm{M}$ & 2 \\
\hline BNLG 469 & $\begin{array}{l}\text { R:AGGGTGTACAGGTCCAAGTCCAA } \\
\text { F:AATGTGGGTCGTCAGCCATCAG }\end{array}$ & 7.05 & $70-65$ & $0,4 \mu \mathrm{M}$ & 2 \\
\hline BNLG 669 & $\begin{array}{l}\text { R:GCACGCACCAGCAGTCGGCAGT } \\
\text { F: CGGCCTAGTGGGCATGGAGCCT }\end{array}$ & 8.03 & $65-55$ & $0,4 \mu \mathrm{M}$ & 4 \\
\hline PHI 115 & $\begin{array}{l}\text { R:CTAGTGGGCGAACAACTGGTAAG } \\
\text { F:AAAGAGACCGTGTCAGGATTGCC }\end{array}$ & 8.04 & $65-55$ & $0,2 \mu \mathrm{M}$ & 2 \\
\hline BNLG 240 & $\begin{array}{l}\text { R:TGCACGTGTATGGGCAGCTA } \\
\text { F:AAGAACAGAAGGCATTGATACATAA }\end{array}$ & 8.06 & $65-55$ & $0,2 \mu \mathrm{M}$ & 3 \\
\hline MACE01C01 & $\begin{array}{l}\text { R:GATGTCGTGTGAGTGACCTG } \\
\text { F:GTGTTGCTATTGCAGTGAGAC }\end{array}$ & 8.08 & $65-55$ & $0,2 \mu \mathrm{M}$ & 4 \\
\hline PHI 015 & $\begin{array}{l}\text { R:GCAACGTACCGTACCTTTCCGA } \\
\text { F:ACGCTGCATTCAATTACCGGGAAG }\end{array}$ & 8.08 & $65-55$ & $0,2 \mu \mathrm{M}$ & 2 \\
\hline BMC1724 & $\begin{array}{l}\text { R:CTGACCCAGAGCATTGTGAA } \\
\text { F:GATGAAGAGCTTGCAGTCCC }\end{array}$ & 9.00 & $65-55$ & $0,2 \mu \mathrm{M}$ & 2 \\
\hline BMC2122 & $\begin{array}{l}\text { R:TCATCTGGCAAAACCTAGCC } \\
\text { F:CTTGCCAACTTGAGGACATG }\end{array}$ & 9.01 & $65-55$ & $0,2 \mu \mathrm{M}$ & 3 \\
\hline PHI 028 & $\begin{array}{l}\text { R:TCTCGCTGTCCTTCGATTAGTACGG } \\
\text { F:AATGCAGGCGATGGTTCTCCGGCCT }\end{array}$ & 9.01 & $65-55$ & $0,2 \mu \mathrm{M}$ & 2 \\
\hline PHI 033 & $\begin{array}{l}\text { R:ATCGAAATGCAGGCGATGGTTCTC } \\
\text { F:ATCGAGATGTTCTACGCCCTGAAGT }\end{array}$ & 9.01 & $70-65$ & $0,4 \mu \mathrm{M}$ & 3 \\
\hline BNLG 244 & $\begin{array}{l}\mathrm{R}: \mathrm{CTCCTCCACTCATCAGCCTTGA} \\
\mathrm{F}: \text { GATGCTACTACTGGTCTAGTCCAGA }\end{array}$ & 9.02 & $70-65$ & $0,4 \mu \mathrm{M}$ & 5 \\
\hline PHI 027 & $\begin{array}{l}\text { R:CACAGCACGTTGCGGATTTCTCT } \\
\text { F:GCGTACGTACGACGAAGACAC }\end{array}$ & 9.03 & $65-55$ & $0,2 \mu \mathrm{M}$ & 2 \\
\hline BNLG 127 & $\begin{array}{l}\text { R:ATCGTAACTCAGCGGTTTGTG } \\
\text { F:CATGTATACGAGAAGCACCTAT }\end{array}$ & 9.04 & $65-55$ & $0,2 \mu \mathrm{M}$ & 2 \\
\hline
\end{tabular}


Tabela 3. "Primers" microssatélites, suas seqüências, sua localização nos cromossomos, número de alelos detectados e as condições de amplificações de cada um deles.

\begin{tabular}{|c|c|c|c|c|c|}
\hline Primers & Sequências Flanqueadoras & Crom./bin & $\begin{array}{c}\text { Temp. } \\
\text { anel. }\left({ }^{0} \mathrm{C}\right)\end{array}$ & $\begin{array}{l}\text { Primer } \\
\text { (mM) }\end{array}$ & $\begin{array}{l}\text { No. de } \\
\text { alelos }\end{array}$ \\
\hline \multirow[t]{2}{*}{ BMC1012 } & R:GAGTGAGCGTGCGGAGTC & 9.05 & $65-55$ & $0,2 \mu \mathrm{M}$ & 4 \\
\hline & F:AACAGGCCAAACTCCTCCTC & & & & \\
\hline \multirow[t]{2}{*}{ BNLG 619} & R:ACCCATCCCACTTTCCACСТССТССT & 9.07 & $65-55$ & $0,2 \mu \mathrm{M}$ & 3 \\
\hline & F:GCTTTCAGCGAATACTGAATAACGCGGA & & & & \\
\hline \multirow[t]{2}{*}{ PHI 117} & R:ATCGGATCGGCTGCCGTCAAA & 10.00 & $65-55$ & $0,2 \mu \mathrm{M}$ & 2 \\
\hline & F:AGACACGACGGTGTGTCCATC & & & & \\
\hline \multirow[t]{2}{*}{ PHI 052} & R:CAGAATGGGACGACAAGGTCATC & 10.02 & $65-55$ & $0,2 \mu \mathrm{M}$ & 2 \\
\hline & F:GGGACACTTCTAGCAGGATCTGTIT & & & & \\
\hline \multirow[t]{2}{*}{ PHI 062} & R:CCAACCCGCTAGGCTACTTCAA & 10.04 & $65-55$ & $0,2 \mu \mathrm{M}$ & 2 \\
\hline & F:ATGCCATGCGTTCGCTCTGTATC & & & & \\
\hline \multirow[t]{2}{*}{ PHI 035} & R:CGTGCAAGCAGTCCTCCCAG & 10.05 & $65-55$ & $0.2 \mu \mathrm{M}$ & 2 \\
\hline & F:CTCCCTGATGAGCTAGAAAGG & & & & \\
\hline \multirow[t]{2}{*}{ BMC1250 } & R:CCATATATTGCCGTGGAAGG & 10.06 & $65-55$ & $0,2 \mu \mathrm{M}$ & 4 \\
\hline & F:TTCTTCATGCACACAGTTGC & & & & \\
\hline \multirow[t]{2}{*}{ MACT02B10 } & R:AAATAGTCCAGAAAAAAATAGTGTG & Näo & $65-55$ & $0,2 \mu \mathrm{M}$ & 5 \\
\hline & F:ACCTCTTGTITCCACAGTTC & mapeado & & & \\
\hline
\end{tabular}


Tabela 4. Número de bandas monomórficas e polimórficas totais e dentro das populações BR-105 e BR-106 obtidas com o marcador AFLP.

\begin{tabular}{ccccccc}
\hline $\begin{array}{c}\text { Combinações } \\
\text { de primers }\end{array}$ & \multicolumn{3}{c}{ Polimórficas } & Monomórficas & Total \\
\cline { 2 - 4 } E-AAC/M-CAC & 30 & BR-106 & Total & & \\
E-AAC/M-CAG & 31 & 32 & 37 & 11 & 48 \\
E-AAC/M-CAT & 23 & 24 & 37 & 08 & 55 \\
E-AAC/M-CTA & 35 & 34 & 39 & 20 & 51 \\
E-AAC/M-CTC & 57 & 51 & 60 & 09 & 48 \\
E-AAC/M-CTG & 25 & 35 & 36 & 12 & 72 \\
E-AAC/M-CT & 36 & 35 & 41 & 14 & 50 \\
E-AAG/M-CAA & 17 & 17 & 20 & 23 & 57 \\
E-AAG/M-CAC & 38 & 45 & 52 & 12 & 43 \\
E-AAG/M-CAG & 09 & 06 & 10 & 12 & 64 \\
E-AAG/M-CAT & 36 & 38 & 43 & 25 & 22 \\
E-AAG/M-CTC & 29 & 28 & 33 & 29 & 68 \\
E-AAG/M-CTG & 47 & 48 & 62 & 19 & 62 \\
E-AAG/M-CTT & 42 & 40 & 50 & 20 & 81 \\
E-ACA/M-CAC & 18 & 21 & 24 & 18 & 70 \\
E-ACA/M-CAG & 17 & 21 & 24 & 14 & 42 \\
E-ACA/M-CAT & 25 & 45 & 48 & 15 & 38 \\
E-ACA/M-CTA & 29 & 43 & 46 & 19 & 63 \\
E-ACA/M-CTC & 23 & 28 & 31 & 20 & 65 \\
E-ACA/M-CTG & 31 & 35 & 40 & 10 & 51 \\
\hline Total & 598 & 664 & 774 & 326 & 50 \\
\hline Média & 29,9 & 33,2 & 38,7 & 16,3 & 55,0 \\
\hline
\end{tabular}

Tabela 5. Comparação dos níveis de polimorfismos obtidos com os marcadores SSR e AFLP em duas populações de milho.

\begin{tabular}{lccccc}
\hline $\begin{array}{l}\text { Marcador } \\
\text { molecular }\end{array}$ & $\begin{array}{c}\text { Número de } \\
\text { unidades } \\
\text { analisadas }\end{array}$ & $\begin{array}{c}\text { Número de } \\
\text { locos por } \\
\text { unidade } \\
\text { analisada }\end{array}$ & $\begin{array}{c}\text { Número } \\
\text { médio de } \\
\text { alelos por } \\
\text { loco }\end{array}$ & $\begin{array}{c}\text { Média de } \\
\text { bandas por } \\
\text { unidade } \\
\text { analisada }\end{array}$ & $\begin{array}{c}\text { Número de } \\
\text { bandas } \\
\text { polimórficas }\end{array}$ \\
\hline SSR & 68 & 1 & 2,94 & 2,94 & 200 \\
AFLP & 20 & $774^{*}$ & 2 & 38,7 & 774 \\
\hline
\end{tabular}

*Número máximo teórico de locos 


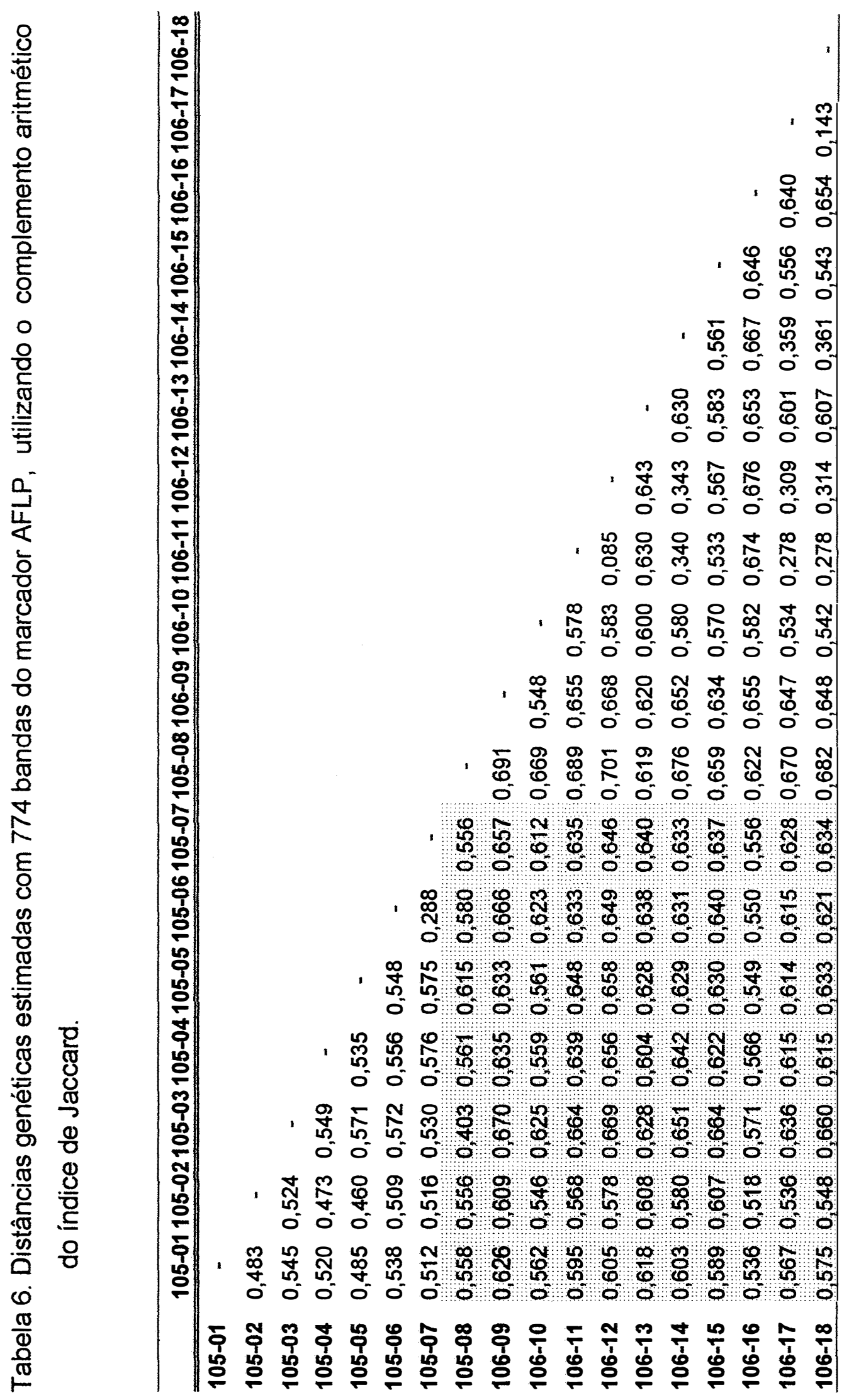




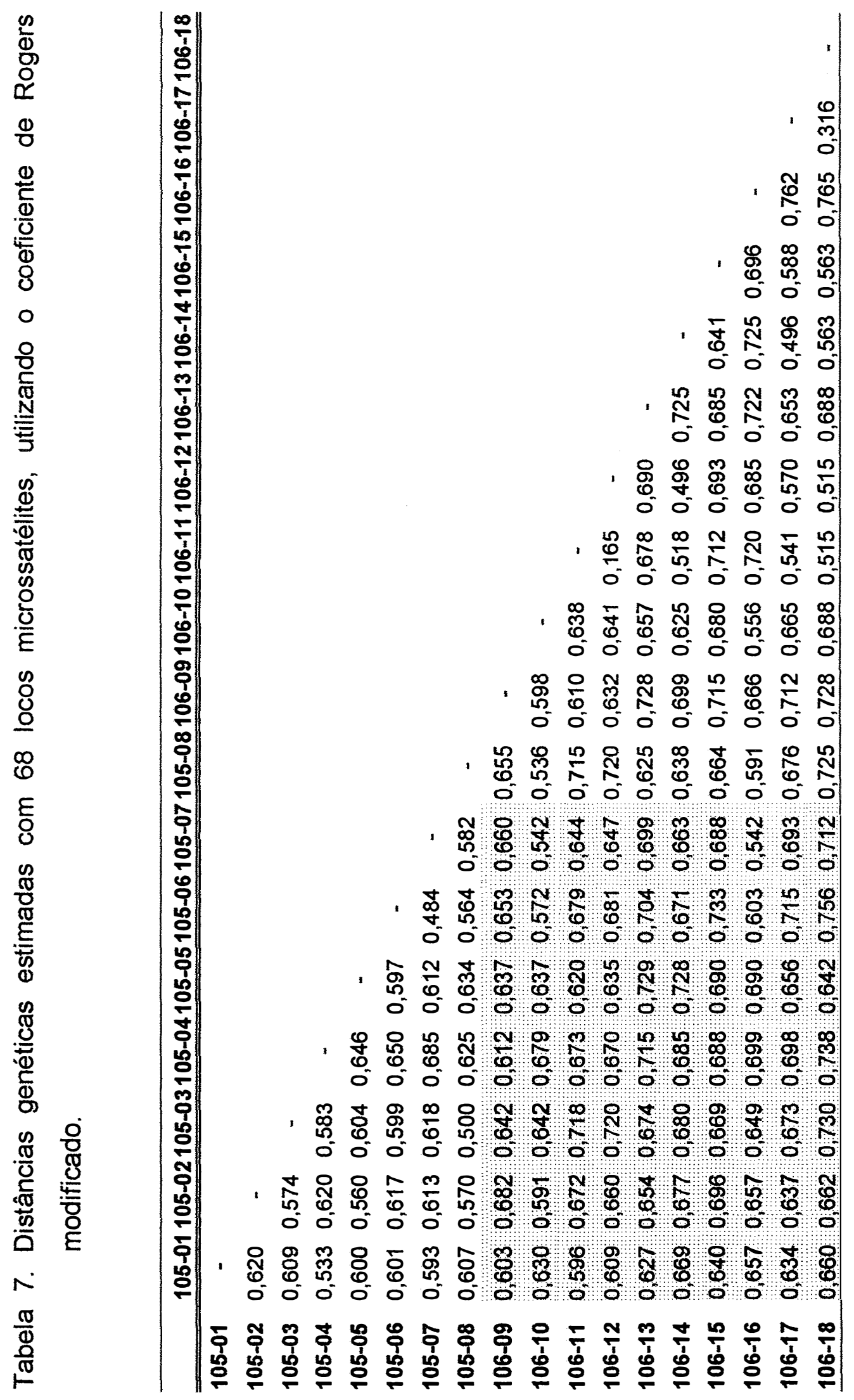


Tabela 8. Número de híbridos ( $N$ ), média, máximo, mínimo e desvio padrão obtido das distâncias genéticas com o marcador AFLP.

\begin{tabular}{lccccc}
\hline Híbridos & N & Média & Máximo & Mínimo & Desvio Padrão \\
\hline BR-105 & 28 & 0,5253 & 0,6154 & 0,2883 & 0,0637 \\
BR-106 & 45 & 0,5375 & 0,6766 & 0,0852 & 0,1502 \\
BR105 x BR106 & 80 & 0,6203 & 0,7016 & 0,5182 & 0,0407 \\
Entre todos & 153 & 0,5786 & 0,7016 & 0,0852 & 0,1003 \\
\hline
\end{tabular}

Tabela 9. Número de híbridos ( $N$ ), média, máximo, mínimo e desvio padrão obtido das distâncias genéticas com o marcador SSR.

\begin{tabular}{lccccc}
\hline Híbridos & $\mathrm{N}$ & Média & Máximo & Mínimo & Desvio Padrão \\
\hline BR-105 & 28 & 0,5969 & 0,6863 & 0,4844 & 0,0424 \\
BR-106 & 45 & 0,6298 & 0,7654 & 0,1654 & 0,1136 \\
BR105 x BR106 & 80 & 0,6625 & 0,7563 & 0,5360 & 0,0461 \\
Entre todos & 153 & 0,6409 & 0,7654 & 0,1654 & 0,0761 \\
\hline
\end{tabular}

Tabela 10. Média, desvio padrão e amplitude de variação para produção de grãos ( $t \mathrm{ha}^{-1}$ ) e heterose, das diferentes combinações de linhagens dentro e entre grupos heteróticos.

\begin{tabular}{lccccc}
\hline $\begin{array}{l}\text { Combinaçăo de } \\
\text { linhagens }\end{array}$ & $\begin{array}{c}\text { No. de } \\
\text { híbridos }\end{array}$ & \multicolumn{2}{c}{$\begin{array}{c}\text { Produção de } \\
\text { grãos F1 (PG) }\end{array}$} & Heterose (PG) \\
\cline { 3 - 6 } & & Média (DP) & Amplitude & Média (DP) & Amplitude \\
\hline BR105 x BR105 & 28 & $6,61(0,86)$ & $4,37-8,26$ & $4,45(0,83)$ & $2,50-5,92$ \\
BR106 $\times$ BR106 & 40 & $6,25(1,47)$ & $3,09-8,45$ & $3,78(1,55)$ & $0,44-6,65$ \\
BR105 BR106 & 80 & $6,80(0,69)$ & $3,81-8,30$ & $4,51(0,74)$ & $1,87-6,40$ \\
Entre todos & 148 & $6,62(1,01)$ & $3,09-8,45$ & $4,30(1,08)$ & $0,44-6,65$ \\
\hline
\end{tabular}

a Os cruzamentos entre a linhagem BR106-16 com BR106-09, BR106-10 e BR106-15 foram excluídos. $O$ cruzamento entre as linhagens irmãs BR106- 11 e BR106-12 foi excluido. 
Tabela 11. Distâncias genéticas obtidas com os marcadores SSR e AFLP, produção de grãos e heterose dos 80 cruzamentos interpopulacionais entre as linhagens da população BR105 e BR106.

\begin{tabular}{|c|c|c|c|c|}
\hline \multirow[t]{2}{*}{ BR105 $\times$ BR106 } & \multicolumn{2}{|c|}{ Distâncias Genéticas } & \multirow{2}{*}{$\begin{array}{l}\text { Produção } \\
\text { de Grãos }\end{array}$} & \multirow[t]{2}{*}{ Heterose } \\
\hline & SSR & AFLP & & \\
\hline $01 \times 09$ & 0,6030 & 0,6263 & 7,20 & 4,82 \\
\hline $01 \times 10$ & 0,6307 & 0,5625 & 6,03 & 3,88 \\
\hline $01 \times 11$ & 0,5962 & 0,5957 & 7,13 & 4,60 \\
\hline $01 \times 12$ & 0,6092 & 0,6058 & 6,79 & 4,33 \\
\hline $01 \times 13$ & 0,6276 & 0,6188 & 7,52 & 3,91 \\
\hline $01 \times 14$ & 0,6691 & 0,6036 & 6,69 & 4,31 \\
\hline $01 \times 15$ & 0,6407 & 0,5898 & 6,94 & 4,99 \\
\hline $01 \times 16$ & 0,6579 & 0,5363 & 6,33 & 4,46 \\
\hline $01 \times 17$ & 0,6343 & 0,5678 & 6,72 & 4,11 \\
\hline $01 \times 18$ & 0,6600 & 0,5756 & 6,49 & 4,00 \\
\hline $02 \times 09$ & 0,6822 & 0,6099 & 6,73 & 4,55 \\
\hline $02 \times 10$ & 0,5948 & 0,5460 & 6,19 & 4,14 \\
\hline $02 \times 11$ & 0,6726 & 0,5682 & 6,60 & 4,17 \\
\hline $02 \times 12$ & 0,6607 & 0,5781 & 6,57 & 4,22 \\
\hline $02 \times 13$ & 0,6542 & 0,6083 & 6,80 & 3,30 \\
\hline $02 \times 14$ & 0,6770 & 0,5808 & 7,16 & 4,89 \\
\hline $02 \times 15$ & 0,6963 & 0,6075 & 7,50 & 5,66 \\
\hline $02 \times 16$ & 0,6571 & 0,5182 & 5,90 & 4,14 \\
\hline $02 \times 17$ & 0,6374 & 0,5363 & 6,61 & 4,10 \\
\hline $02 \times 18$ & 0,6629 & 0,5489 & 7,02 & 4,64 \\
\hline $03 \times 09$ & 0,6426 & 0,6708 & 6,15 & 3,91 \\
\hline $03 \times 10$ & 0,6426 & 0.6253 & 5.96 & 3,86 \\
\hline $03 \times 11$ & 0,7181 & $\begin{array}{l}0,0203 \\
0,6647\end{array}$ & $\begin{array}{l}0,50 \\
6,86\end{array}$ & $\begin{array}{l}3,00 \\
4.37\end{array}$ \\
\hline $03 \times 12$ & 0,7208 & $\begin{array}{l}0,0041 \\
0,6693\end{array}$ & $\begin{array}{l}0,00 \\
6,60\end{array}$ & $\begin{array}{l}4,31 \\
4.20\end{array}$ \\
\hline $03 \times 13$ & 0,6747 & 0,6287 & 6,60 & 3,04 \\
\hline $03 \times 14$ & 0,6802 & 0,6518 & 6,84 & 4,51 \\
\hline $03 \times 15$ & 0,6691 & 0,6646 & 5,15 & 3,24 \\
\hline $03 \times 16$ & 0,6493 & 0,5711 & 4,65 & 2,84 \\
\hline $03 \times 17$ & 0,6737 & 0,6360 & 6,42 & 3,85 \\
\hline $03 \times 18$ & 0,7305 & 0,6607 & 6,35 & 3,92 \\
\hline $04 \times 09$ & 0,6124 & 0,6358 & 7,39 & 5,03 \\
\hline $04 \times 10$ & 0,6798 & 0,5593 & 6.03 & 3,80 \\
\hline $04 \times 11$ & 0,6731 & 0,6394 & 6,95 & 4,34 \\
\hline $04 \times 12$ & 0,6702 & 0,6563 & 6,60 & 4,07 \\
\hline $04 \times 13$ & 0,7151 & 0,6040 & 6,97 & 3,29 \\
\hline $04 \times 14$ & 0,6857 & 0,6422 & 6,82 & 4,37 \\
\hline $04 \times 15$ & 0,6884 & 0,6223 & 7,89 & 5,87 \\
\hline $04 \times 16$ & 0,6991 & 0,5667 & 3,81 & 1,87 \\
\hline $04 \times 17$ & 0,6988 & 0,6151 & 6,93 & 4,24 \\
\hline $04 \times 18$ & 0,7385 & 0,6154 & 6,74 & 4,18 \\
\hline $05 \times 09$ & 0,6374 & 0,6337 & 5,68 & 3,45 \\
\hline $05 \times 10$ & 0,6374 & 0,5618 & 6,77 & 4,66 \\
\hline $05 \times 11$ & 0,6204 & 0,6483 & 7,60 & 5,12 \\
\hline $05 \times 12$ & 0,6350 & 0,6582 & 7,59 & 5,19 \\
\hline $05 \times 13$ & 0,7292 & 0,6286 & 7,41 & 3,86 \\
\hline
\end{tabular}


Tabela 11. Distâncias genéticas obtidas com os marcadores SSR e AFLP, produção de grãos e heterose dos 80 cruzamentos interpopulacionais entre as linhagens da população BR105 e BR106.

\begin{tabular}{|c|c|c|c|c|}
\hline \multirow{2}{*}{ BR105 x BR106 } & \multicolumn{2}{|c|}{ Distâncias Genéticas } & \multirow{2}{*}{$\begin{array}{l}\text { Produção } \\
\text { de Grãos }\end{array}$} & \multirow[t]{2}{*}{ Heterose } \\
\hline & SSR & AFLP & & \\
\hline $05 \times 14$ & 0,7289 & 0,6296 & 7,53 & 5,21 \\
\hline $05 \times 15$ & 0,6903 & 0,6307 & 8,30 & 6,40 \\
\hline $05 \times 16$ & 0,6903 & 0,5499 & 7,20 & 5,38 \\
\hline $05 \times 17$ & 0,6568 & 0,6145 & 7,07 & 4,51 \\
\hline $05 \times 18$ & 0,6424 & 0,6339 & 6,78 & 4,35 \\
\hline $06 \times 09$ & 0,6534 & 0,6667 & 6,98 & 5,26 \\
\hline $06 \times 10$ & 0,5718 & 0,6236 & 6,90 & 5,31 \\
\hline $06 \times 11$ & 0,6789 & 0,6338 & 8,00 & 6,04 \\
\hline $06 \times 12$ & 0,6814 & 0,6494 & 7,68 & 5,79 \\
\hline $06 \times 13$ & 0,7044 & 0,6388 & 7,47 & 4,43 \\
\hline $06 \times 14$ & 0,6714 & 0,6311 & 6,35 & 4,54 \\
\hline $06 \times 15$ & 0,7334 & 0,6409 & 7,07 & 5,69 \\
\hline $06 \times 16$ & 0,6030 & 0,5506 & 6,53 & 5,23 \\
\hline $06 \times 17$ & 0,7153 & 0,6158 & 6,85 & 4,81 \\
\hline $06 \times 18$ & 0,7563 & 0,6217 & 7,31 & 5,40 \\
\hline $07 \times 09$ & 0,5916 & 0,6576 & 7,42 & 5,23 \\
\hline $07 \times 10$ & 0,5429 & 0,6123 & 6,80 & 4,75 \\
\hline $07 \times 11$ & 0,6445 & 0,6358 & 7,44 & 5,00 \\
\hline $07 \times 12$ & 0,6475 & 0,6460 & 7,82 & 5,47 \\
\hline $07 \times 13$ & 0,6990 & 0,6409 & 7,72 & 4,21 \\
\hline $07 \times 14$ & 0,6635 & 0,6332 & 6,92 & 4,64 \\
\hline $07 \times 15$ & 0,6884 & 0,6373 & 7,17 & 5,32 \\
\hline $07 \times 16$ & 0,5429 & 0,5561 & 5,79 & 4,03 \\
\hline $07 \times 17$ & 0,6934 & 0,6287 & 7,35 & 4,84 \\
\hline $07 \times 18$ & 0,7124 & 0,6347 & 7,00 & 4,60 \\
\hline $08 \times 09$ & 0,6551 & 0,6913 & 6,67 & 4,72 \\
\hline $08 \times 10$ & 0,5360 & 0,6696 & 6,29 & 4,46 \\
\hline $08 \times 11$ & 0,7152 & 0,6892 & 7,16 & 4,95 \\
\hline $08 \times 12$ & 0,7206 & 0,7016 & 6,88 & 4,76 \\
\hline $08 \times 13$ & 0,6259 & 0,6193 & 7,16 & 3,89 \\
\hline $08 \times 14$ & 0,6388 & 0,6769 & 6,75 & 4,71 \\
\hline $08 \times 15$ & 0,6642 & 0,6596 & 6,55 & 4,93 \\
\hline $08 \times 16$ & 0,5910 & 0,6225 & 6,19 & 4,66 \\
\hline $08 \times 17$ & 0,6765 & 0,6706 & 6,69 & 4,40 \\
\hline $08 \times 18$ & 0,7253 & 0,6825 & 6,92 & 4,77 \\
\hline
\end{tabular}


Tabela 12. Distâncias genéticas obtidas com os marcadores SSR e AFLP, produção de grãos e heterose dos 40 cruzamentos intrapopulacionais entre as linhagens da população BR106.

\begin{tabular}{|c|c|c|c|c|}
\hline \multirow[t]{2}{*}{ BR106 × BR106 } & \multicolumn{2}{|c|}{ Distâncias Genéticas } & \multirow{2}{*}{$\begin{array}{l}\text { Produçảo } \\
\text { de Grãos }\end{array}$} & \multirow[t]{2}{*}{ Heterose } \\
\hline & SSR & AFLP & & \\
\hline $09 \times 10$ & 0,5985 & 0,5482 & 5,66 & 3,66 \\
\hline $09 \times 11$ & 0,6108 & 0,6551 & 7,46 & 5,08 \\
\hline $09 \times 12$ & 0,6300 & 0,6680 & 6,55 & 4,25 \\
\hline $09 \times 13$ & 0,7282 & 0,6201 & 6,87 & 3,41 \\
\hline $09 \times 14$ & 0,6991 & 0,6528 & 7,09 & 4,87 \\
\hline $09 \times 15$ & 0,7150 & 0,6342 & 7,85 & 6,06 \\
\hline $09 \times 17$ & 0,7125 & 0,6474 & 5,96 & 3,51 \\
\hline $09 \times 18$ & 0,7282 & 0,6484 & 7,75 & 5,42 \\
\hline $10 \times 11$ & 0,6385 & 0,5783 & 6,94 & 4,69 \\
\hline $10 \times 12$ & 0,6415 & 0,5835 & 5,37 & 3,20 \\
\hline $10 \times 13$ & 0,6571 & 0,6000 & 8,10 & 4,78 \\
\hline $10 \times 14$ & 0,6259 & 0,5800 & 6,19 & 4,10 \\
\hline $10 \times 15$ & 0,6802 & 0,5705 & 6,82 & 5,15 \\
\hline $10 \times 17$ & 0,6651 & 0,5349 & 6,57 & 4,25 \\
\hline $10 \times 18$ & 0,6881 & 0,5420 & 6,50 & 4,30 \\
\hline $11 \times 13$ & 0,6789 & 0,6306 & 7,08 & 3,38 \\
\hline $11 \times 14$ & 0,5189 & 0,3406 & 4,22 & 1,75 \\
\hline $11 \times 15$ & 0,7125 & 0,5339 & 6,59 & 4,55 \\
\hline $11 \times 16$ & 0,7206 & 0,6747 & 7,99 & 6,03 \\
\hline $11 \times 17$ & 0,5419 & 0,2782 & 3,87 & 1,17 \\
\hline $11 \times 18$ & 0,5154 & 0,2787 & 3,53 & 0,96 \\
\hline $12 \times 13$ & 0,6903 & 0,6437 & 7,26 & 3,64 \\
\hline $12 \times 14$ & 0,4961 & 0,3430 & 3,71 & 1,32 \\
\hline $12 \times 15$ & 0,6934 & 0,5675 & 6,09 & 4,13 \\
\hline $12 \times 16$ & 0,6850 & 0,6766 & 7,24 & 5,36 \\
\hline $12 \times 17$ & 0,5704 & 0,3090 & 4,25 & 1,63 \\
\hline $12 \times 18$ & 0,5154 & 0,3141 & 3,80 & 1,31 \\
\hline $13 \times 14$ & 0,7253 & 0,6307 & 7,68 & 4,14 \\
\hline $13 \times 15$ & 0,6857 & 0,5837 & 7,22 & 4,11 \\
\hline $13 \times 17$ & 0,6534 & 0,6012 & 7,78 & 4,01 \\
\hline $13 \times 18$ & 0,6884 & 0,6070 & 6,96 & 3,32 \\
\hline $14 \times 15$ & 0,6417 & 0,5612 & 7,19 & 5,30 \\
\hline $14 \times 16$ & 0,7251 & 0,6673 & 8,45 & 6,65 \\
\hline $14 \times 17$ & 0,4961 & 0,3596 & 4,05 & 1,51 \\
\hline $14 \times 18$ & 0,5632 & 0,3617 & 4,46 & 2,05 \\
\hline $15 \times 17$ & 0,5883 & 0,5565 & 6,59 & 4,47 \\
\hline $15 \times 18$ & 0,5632 & 0,5431 & 5,73 & 3,74 \\
\hline $16 \times 17$ & 0,7621 & 0,6402 & 7,47 & 5,44 \\
\hline $16 \times 18$ & 0,7654 & 0,6546 & 5,96 & 4,00 \\
\hline $17 \times 18$ & 0,3162 & 0,1436 & 3,09 & 0,44 \\
\hline
\end{tabular}

* $O$ cruzamento entre as linhagens irmãs (106-11 x 106-12) e quatro cruzamentos, envolvendo dados de campo perdidos (106-16 com 106-09, 106-10, 106-13 e 106-15), foram excluídos. 
Tabela 13. Distâncias genéticas obtidas com os marcadores SSR e AFLP, produção de grãos e heterose dos 28 cruzamentos intrapopulacionais entre as linhagens da população BR105.

\begin{tabular}{ccccc}
\hline BR105 x BR105 & \multicolumn{2}{c}{ Distâncias Genéticas } & Produção & Heterose \\
\cline { 2 - 3 } & SSR & AFLP & de Grãos & \\
\hline $01 \times 02$ & 0,6202 & 0,4836 & 6,98 & 4,64 \\
$01 \times 03$ & 0,6093 & 0,5458 & 6,65 & 4,25 \\
$01 \times 04$ & 0,5330 & 0,5206 & 6,72 & 4,20 \\
$01 \times 05$ & 0,6009 & 0,4850 & 7,75 & 5,36 \\
$01 \times 06$ & 0,6013 & 0,5386 & 7,15 & 5,27 \\
$01 \times 07$ & 0,5935 & 0,5128 & 8,26 & 5,92 \\
$01 \times 08$ & 0,6078 & 0,5584 & 6,08 & 3,97 \\
$02 \times 03$ & 0,5741 & 0,5248 & 6,35 & 4,06 \\
$02 \times 04$ & 0,6202 & 0,4733 & 6,76 & 4,35 \\
$02 \times 05$ & 0,5608 & 0,4603 & 7,08 & 4,80 \\
$02 \times 06$ & 0,6171 & 0,5090 & 5,79 & 4,02 \\
$02 \times 07$ & 0,6139 & 0,5169 & 5,79 & 3,55 \\
$02 \times 08$ & 0,5708 & 0,5567 & 5,48 & 3,48 \\
$03 \times 04$ & 0,5839 & 0,5490 & 6,40 & 3,93 \\
$03 \times 05$ & 0,6042 & 0,5717 & 6,34 & 4,00 \\
$03 \times 06$ & 0,5999 & 0,5727 & 7,16 & 5,33 \\
$03 \times 07$ & 0,6185 & 0,5302 & 6,65 & 4,36 \\
$03 \times 08$ & 0,5000 & 0,4035 & 4,57 & 2,50 \\
$04 \times 05$ & 0,6465 & 0,5355 & 7,05 & 4,59 \\
$04 \times 06$ & 0,6504 & 0,5567 & 7,06 & 5,12 \\
$04 \times 07$ & 0,6863 & 0,5760 & 6,99 & 4,58 \\
$04 \times 08$ & 0,6259 & 0,5613 & 6,10 & 3,92 \\
$05 \times 06$ & 0,5976 & 0,5488 & 7,63 & 5,82 \\
$05 \times 07$ & 0,6124 & 0,5757 & 7,21 & 4,92 \\
$05 \times 08$ & 0,6343 & 0,6154 & 6,92 & 4,87 \\
$06 \times 07$ & 0,4844 & 0,2883 & 4,37 & 2,59 \\
$06 \times 08$ & 0,5641 & 0,5800 & 7,23 & 5,69 \\
$07 \times 08$ & 0,5827 & 0,5566 & 6,53 & 4,51 \\
\hline
\end{tabular}


Tabela 14. Correlação linear de Pearson entre as médias e heterose de produção de grãos com os dados de distâncias genéticas obtidas com o marcador AFLP.

$\begin{array}{lccc}\text { Hibridos } & \mathbf{N} & \text { Produção de Grãos (PG) } & \text { Heterose (PG) } \\ \text { BR-105 } & 28 & 0,5243^{\star} & 0,5189^{\star} \\ \text { BR-106 } & 40 & 0,9067^{\star \star} & 0,8730^{\star \star} \\ \text { Interpopulacional } & 80 & 0,2930^{\text {ns }} & 0,2269^{\text {ns }} \\ \text { Total } & 148 & 0,7119^{\star \star} & 0,6706^{\star \star}\end{array}$

$\mathrm{N}=$ números de híbridos, ${ }^{*}$ significativo a $5 \%,{ }^{*}$ * significativo a $1 \%$, ns = não significativo.

Tabela 15. Correlação linear de Pearson entre as médias e heterose de produção de grãos com os dados de distâncias genéticas obtidas com o marcador SSR.

\begin{tabular}{lccc} 
Híbridos & N & Produção de Grãos (PG) & Heterose (PG) \\
\hline BR-105 & 28 & $0,5178^{\star}$ & $0,4480^{\text {ns }}$ \\
BR-106 & 40 & $0,8232^{\star \star}$ & $0,7895^{\star \star}$ \\
Interpopulacional & 80 & $0,1643^{\text {ns }}$ & $0,0257^{\text {ns }}$ \\
Total & 148 & $0,5751^{\star \star}$ & $0,4894^{\star \star}$ \\
\hline
\end{tabular}

$N=$ números de híbridos, * significativo a $5 \%$, * * significativo a $1 \%$, ns = não significativo. 
Tabela 16. Valores médios das distâncias genéticas (DG) obtidas com AFLP e produção de grãos (PG) das linhagens 01 a 08 (BR105), em cruzamentos intra e interpopulacionais.

\begin{tabular}{|c|c|c|c|c|c|c|}
\hline \multirow[t]{2}{*}{ Linhagem } & \multicolumn{3}{|c|}{ Intrapopulacional } & \multicolumn{3}{|c|}{ Interpopulacional } \\
\hline & $\mathrm{N}$ & $D G$ & $P G$ & $N$ & DG & $P G$ \\
\hline 01 & 7 & 0,521 & 7,08 & 10 & 0,588 & 6,78 \\
\hline 02 & 7 & 0,503 & 6,32 & 10 & 0,570 & 6,71 \\
\hline 03 & 7 & 0,528 & 6,30 & 10 & 0,644 & 6,16 \\
\hline 04 & 7 & 0,539 & 6,73 & 10 & 0,616 & 6,61 \\
\hline 05 & 7 & 0,542 & 7.14 & 10 & 0,619 & 7,19 \\
\hline 06 & 7 & 0,513 & 6,63 & 10 & 0,627 & 7,11 \\
\hline 07 & 7 & 0,508 & 6,54 & 10 & 0,628 & 7,14 \\
\hline 08 & 7 & 0,547 & 6,13 & 10 & 0,668 & 6,73 \\
\hline Média & & 0,526 & 6,61 & & 0,620 & 6,80 \\
\hline
\end{tabular}

Tabela 17. Valores médios das distâncias genéticas (DG) obtidas com AFLP e produção de grãos (PG) das linhagens 09 a 18 (BR106), em cruzamentos intra e interpopulacionais.

\begin{tabular}{|c|c|c|c|c|c|c|}
\hline \multirow[t]{2}{*}{ Linhagem } & \multicolumn{3}{|c|}{ Intrapopulacional } & \multicolumn{3}{|c|}{ Interpopulacional } \\
\hline & $\mathrm{N}$ & $D G$ & $P G$ & $\mathbf{N}$ & DG & $P G$ \\
\hline 09 & 8 & 0,634 & 6,89 & 8 & 0,649 & 6,78 \\
\hline 10 & 8 & 0,567 & 6,52 & 8 & 0,595 & 6,37 \\
\hline 11 & 8 & 0,496 & 5,96 & 8 & 0,634 & 7,22 \\
\hline 12 & 8 & 0,513 & 5,53 & 8 & 0,645 & 7,07 \\
\hline 13 & 8 & 0,614 & 7,37 & 8 & 0,623 & 7,21 \\
\hline 14 & 9 & 0,500 & 5,89 & 8 & 0,631 & 6,88 \\
\hline 15 & 8 & 0,569 & 6,76 & 8 & 0,632 & 7,07 \\
\hline 16 & 5 & 0,663 & 7,42 & 8 & 0,559 & 5,80 \\
\hline 17 & 9 & 0,452 & 5,51 & 8 & 0,611 & 6,83 \\
\hline 18 & 9 & 0,455 & 5,31 & 8 & 0,622 & 6,83 \\
\hline Média & & 0,546 & 6,34 & & 0,620 & 6,80 \\
\hline
\end{tabular}

$\mathrm{N}$ : Número de observações 


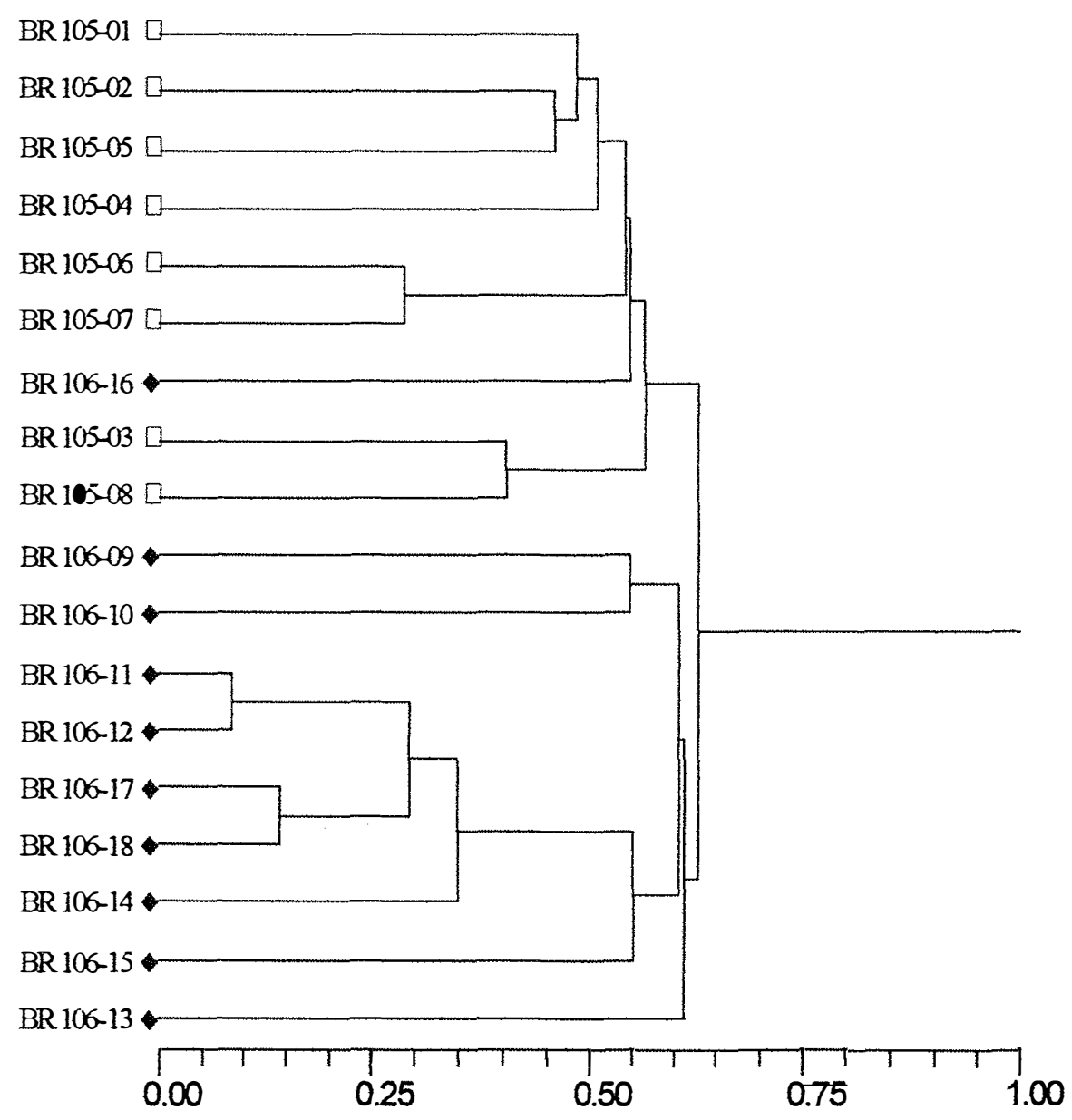

Figura 3 - Dendrograma obtido pelo método UPGMA a partir das distâncias estimadas com 774 bandas de AFLP com o complemento aritmético do índice de Jaccard, entre 18 linhagens de milho. 


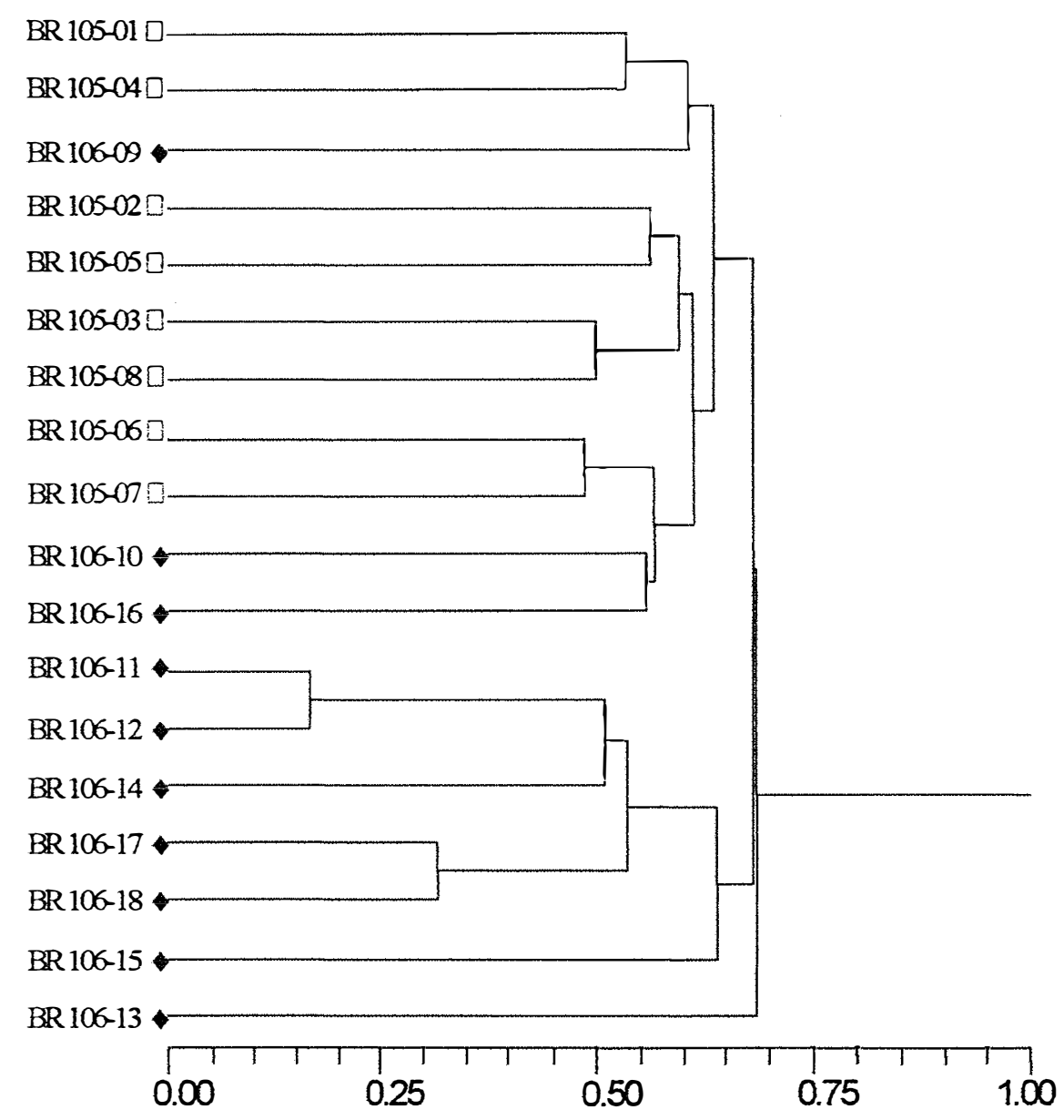

Figura 4 - Dendrograma obtido pelo método UPGMA a partir das distâncias estimadas com o coeficiente de Rogers modificado a partir de 68 locos microssatélites (SSR) entre 18 linhagens de milho. 

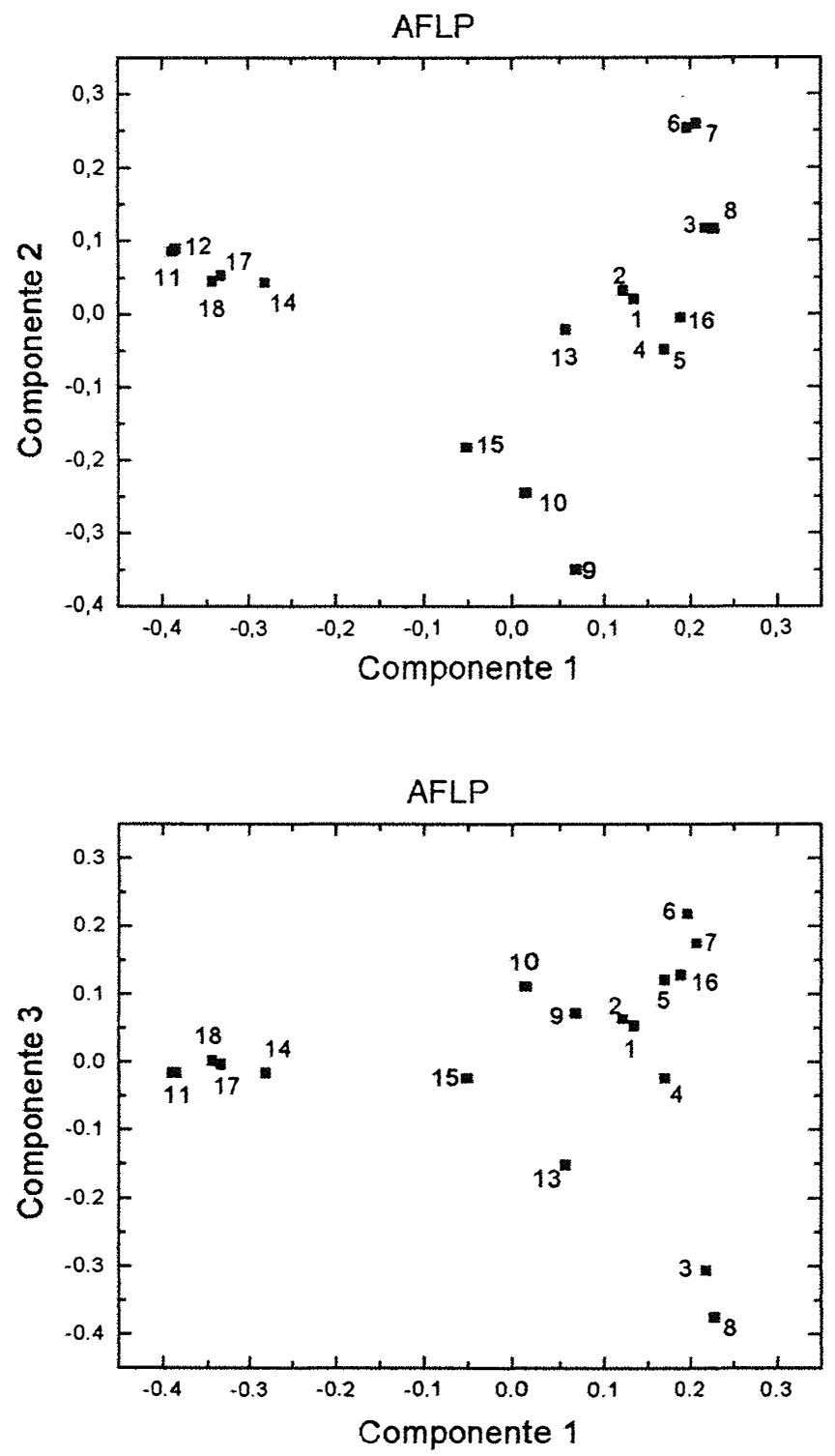

Figura 5 - Análises de coordenadas principais com o marcador AFLP, onde a primeira, segunda e terceira coordenadas têm valor de 18,92; 9,25 e $8,06 \%$, respectivamente. 

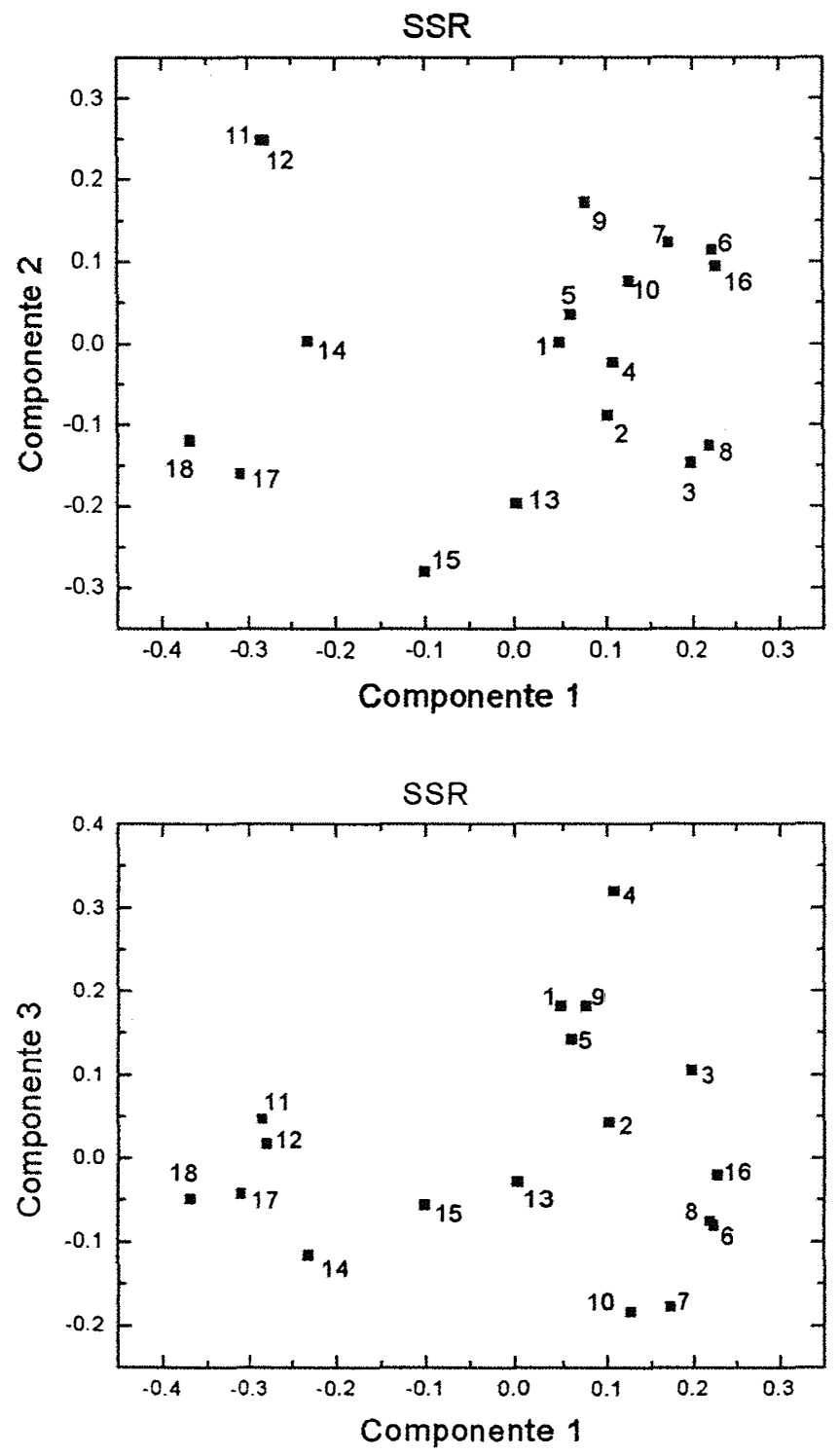

Figura 6 - Análises de coordenadas principais com o marcador SSR, onde a primeira, segunda e terceira coordenadas têm valor de 20,52; 11,$43 ; 9,94 \%$, respectivamente. 
Gráfico com valores do coeficiente de variação para cada temanho amostral AFLP

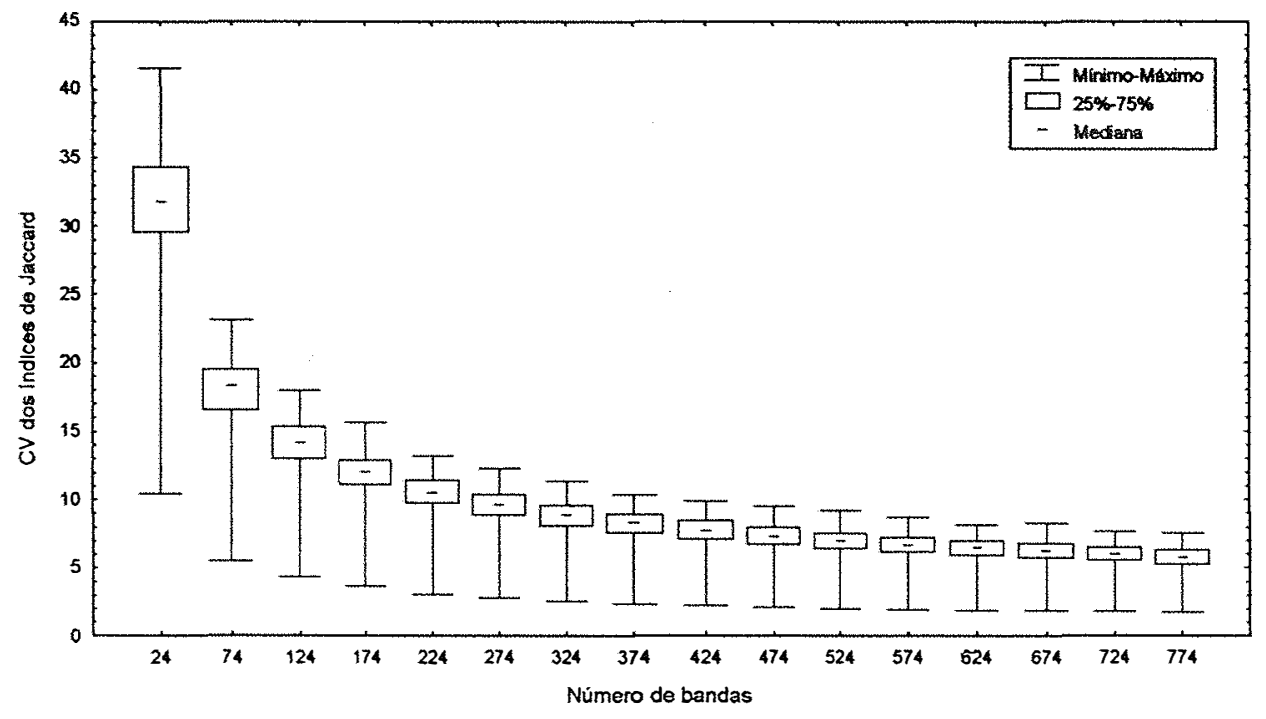

Figura 7 - Coeficiente de variação das distâncias genéticas entre 18 linhagens de milho, de acordo com o número de bandas AFLP reamostrados pela técnica bootstrap.

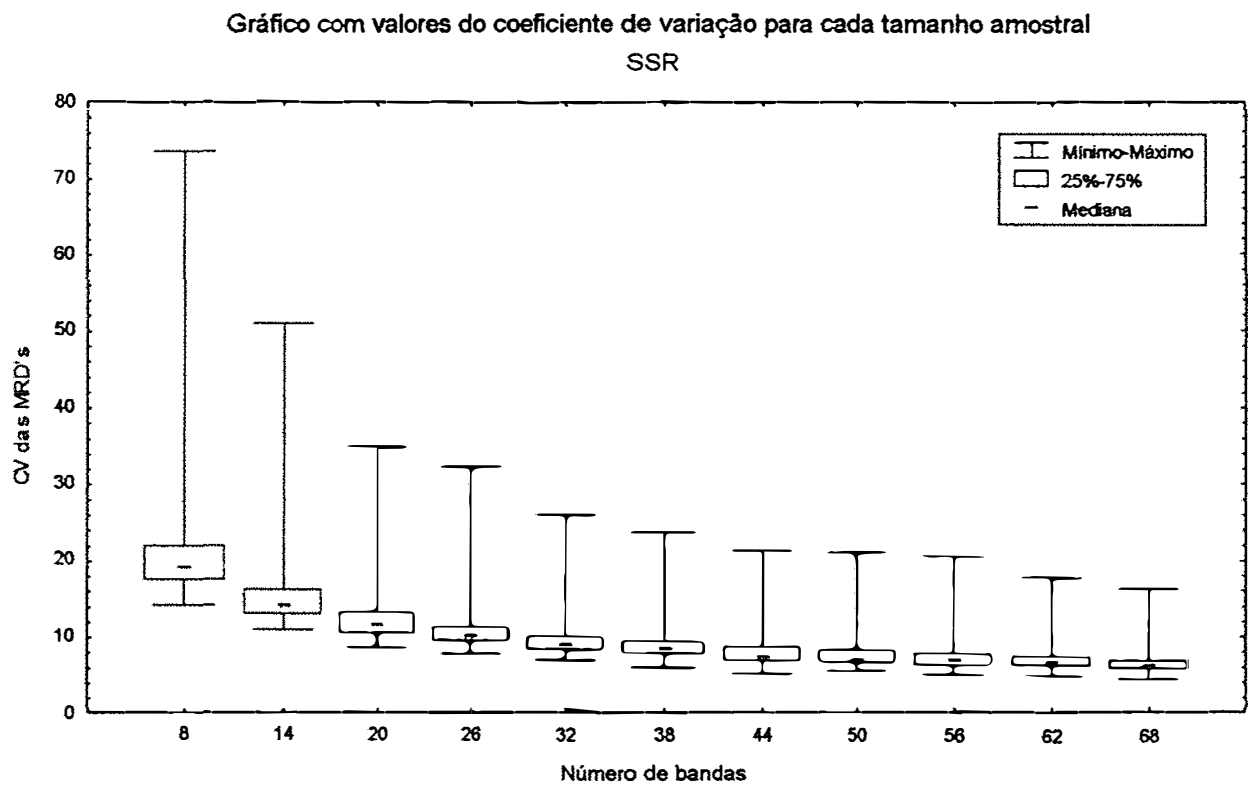

Figura 8 - Coeficiente de variação das distâncias genéticas entre 18 linhagens de milho, de acordo com o número de locos SSRs reamostrados pela técnica bootstrap. 


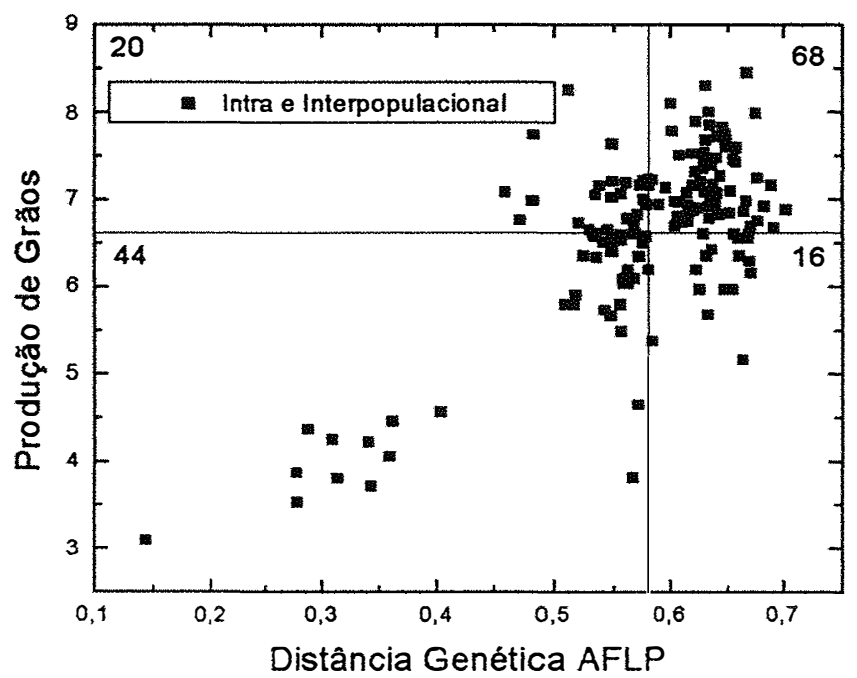

Figura 9 - Dispersão gráfica de 148 híbridos resultantes dos cruzamentos de linhagens das populações BR-105 e BR-106 com relação às distâncias genéticas obtidas com AFLP e produção de grãos.

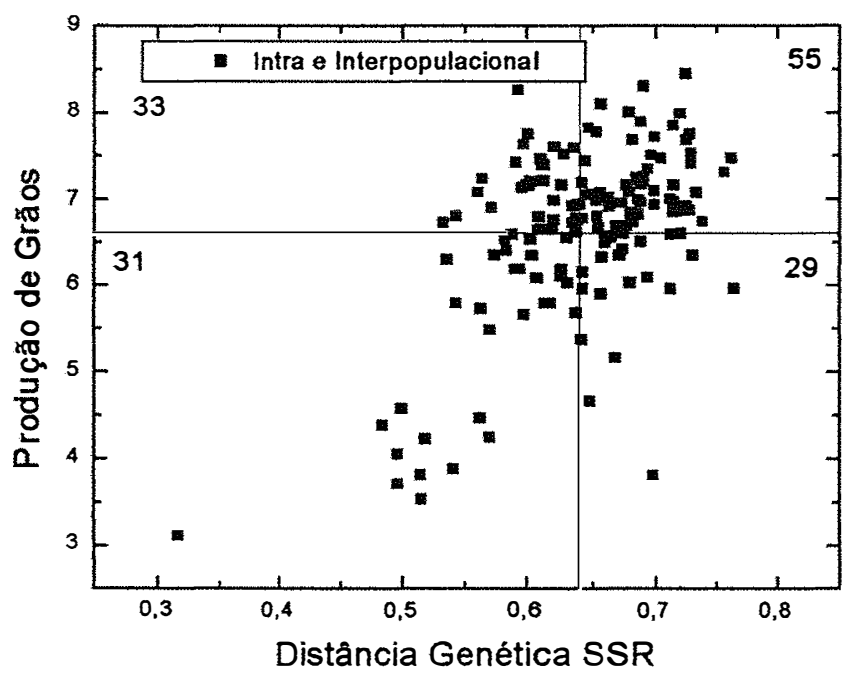

Figura 10 - Dispersão gráfica de 148 híbridos resultantes dos cruzamentos de linhagens das populações BR-105 e BR-106 com relação às distâncias genéticas obtidas com SSR e produção de grãos. 


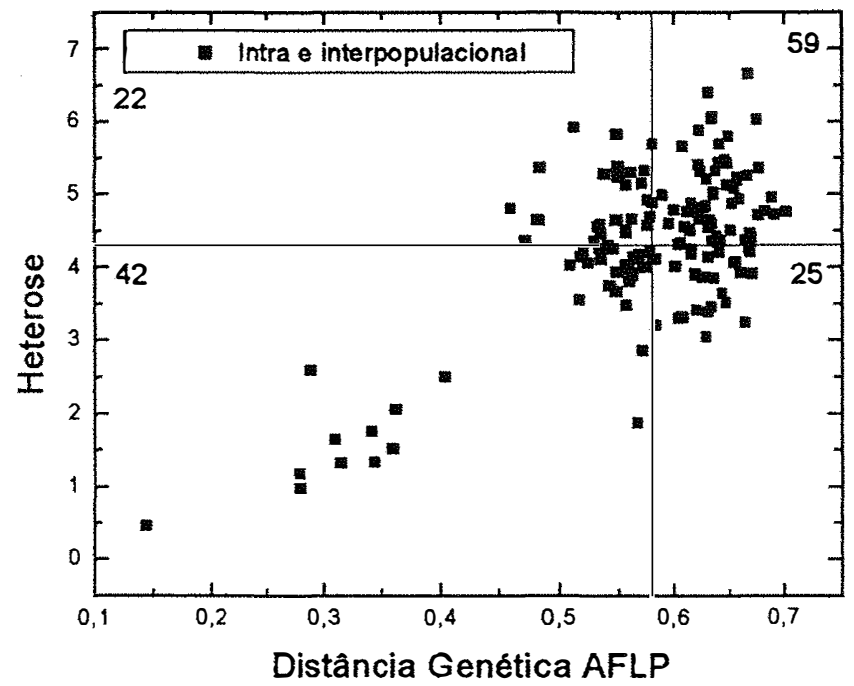

Figura 11 - Dispersão gráfica de 148 híbridos resultantes dos cruzamentos de linhagens das populações BR-105 e BR-106 com relação às distâncias genéticas obtidas com AFLP e heterose para produção de grãos.

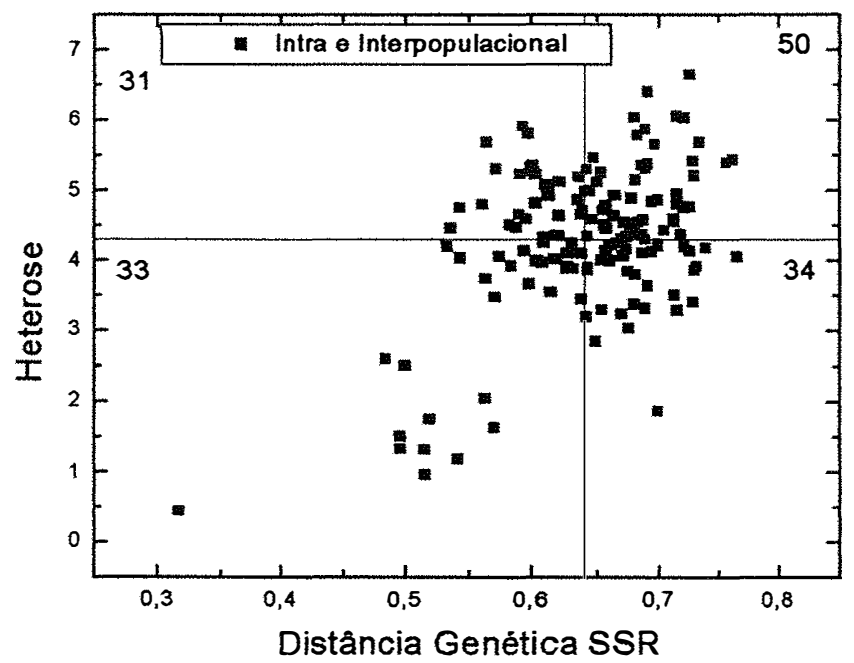

Figura 12 - Dispersão gráfica de 148 híbridos resultantes dos cruzamentos de linhagens das populações BR-105 e BR-106 com relação às distâncias genéticas obtidas com SSR e heterose para produção de grãos. 


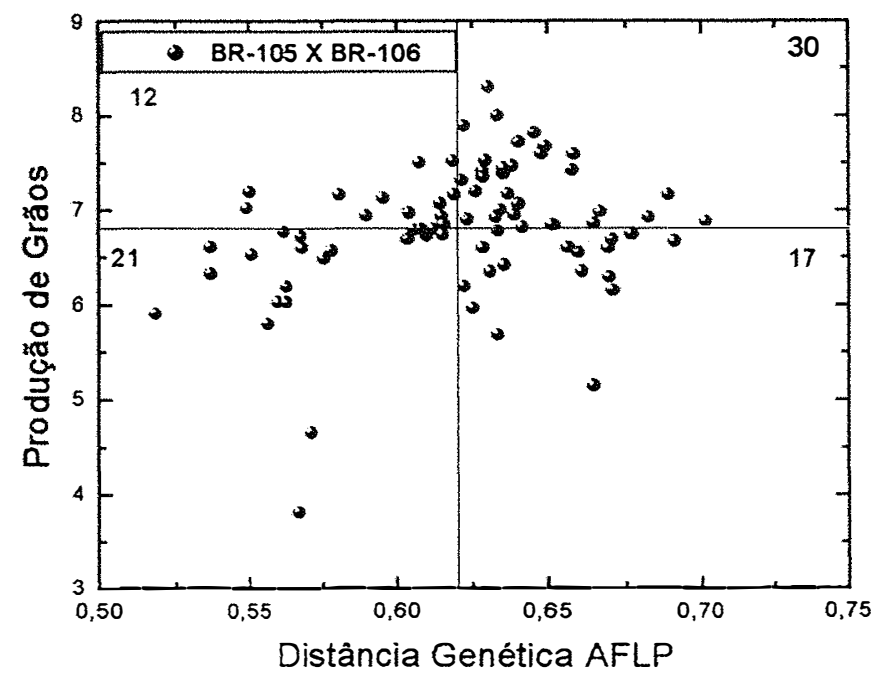

Figura 13 - Dispersão gráfica de 80 híbridos resultantes dos cruzamentos de linhagens das populaçōes BR-105 e BR-106 com relação às distâncias genéticas obtidas com AFLP e produção de grãos.

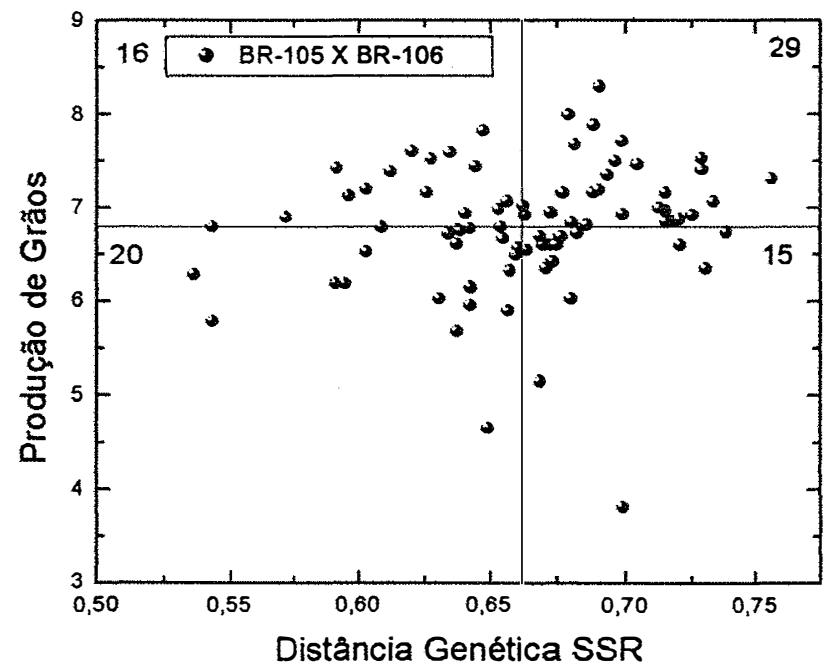

Figura 14 - Dispersão gráfica de 80 híbridos resultantes dos cruzamentos de linhagens das populações BR-105 e BR-106 com relação às distâncias genéticas obtidas com SSR e produção de grãos. 


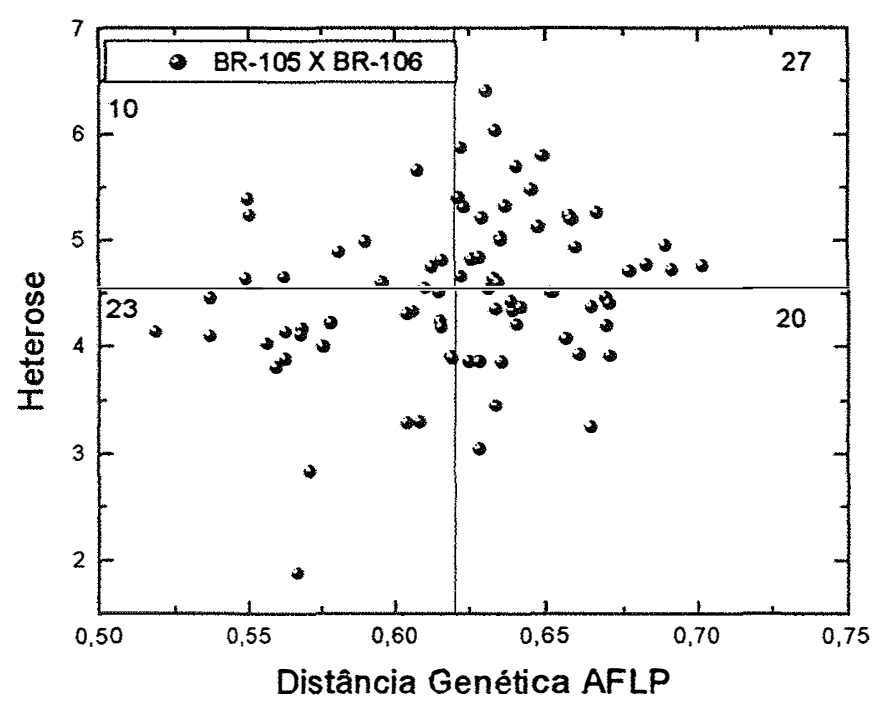

Figura 15 - Dispersão gráfica de 80 híbridos resultantes dos cruzamentos de linhagens das populações BR-105 e BR-106 com relação às distâncias genéticas obtidas com AFLP e heterose para produção de grãos.

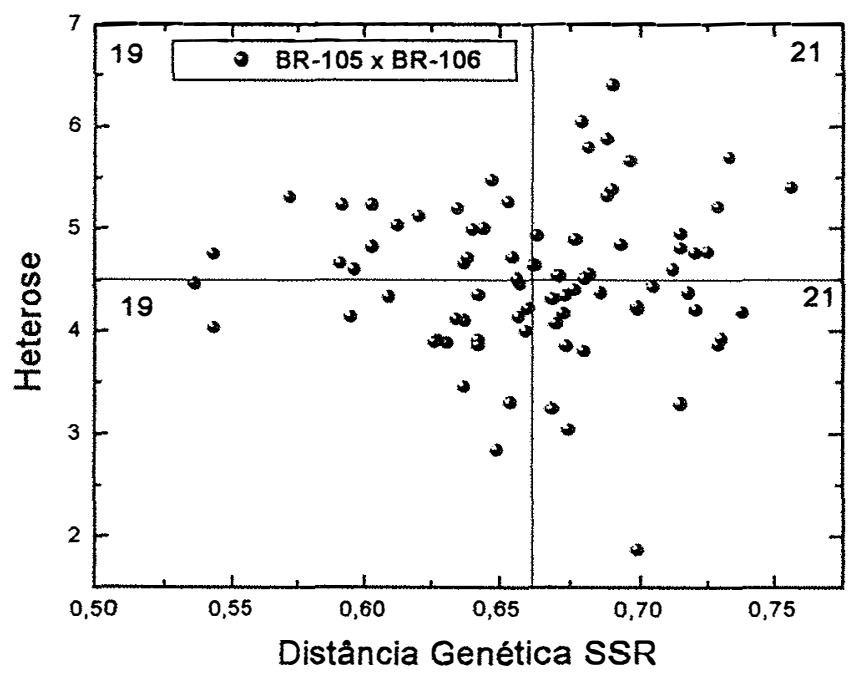

Figura 16 - Dispersão gráfica de 80 híbridos resultantes dos cruzamentos de linhagens das populações BR-105 e BR-106 com relação às distâncias genéticas obtidas com SSR e heterose para produção de grãos. 


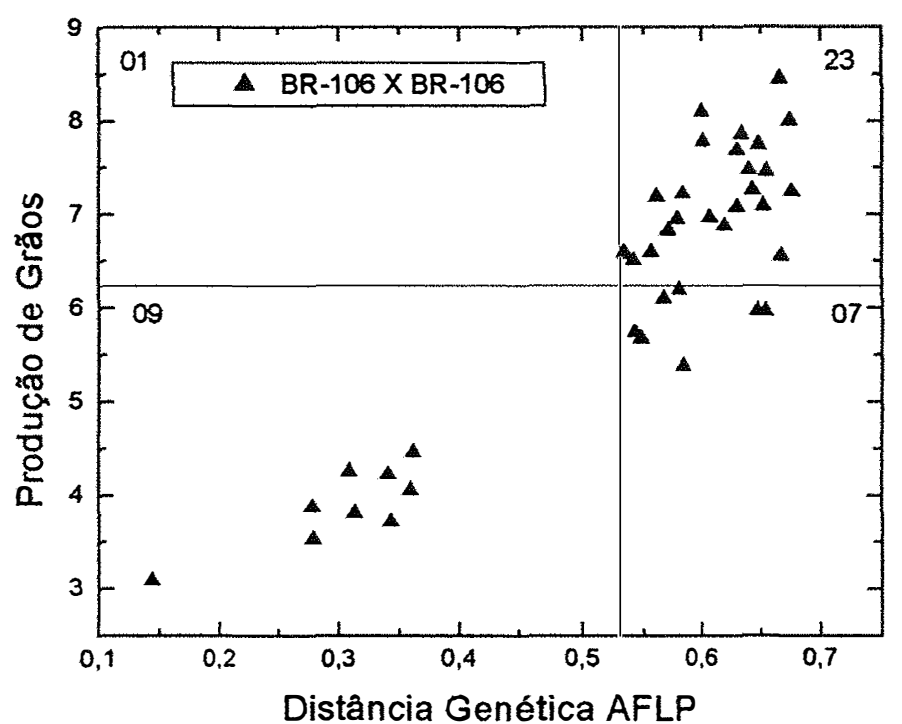

Figura 17 - Dispersão gráfica de 40 híbridos resultantes dos cruzamentos de linhagens dentro da população BR-106 com relação às distâncias genéticas obtidas com AFLP e produção de grãos.

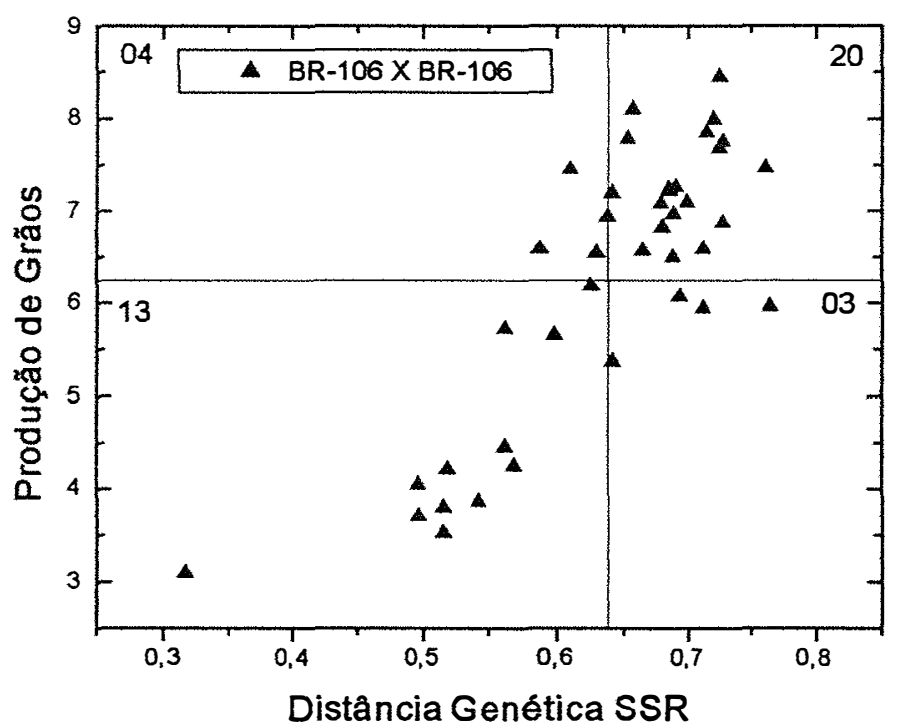

Figura 18 - Dispersão gráfica de 40 híbridos resultantes dos cruzamentos de linhagens dentro da população BR-106 com relação às distâncias genéticas obtidas com SSR e produção de grãos. 


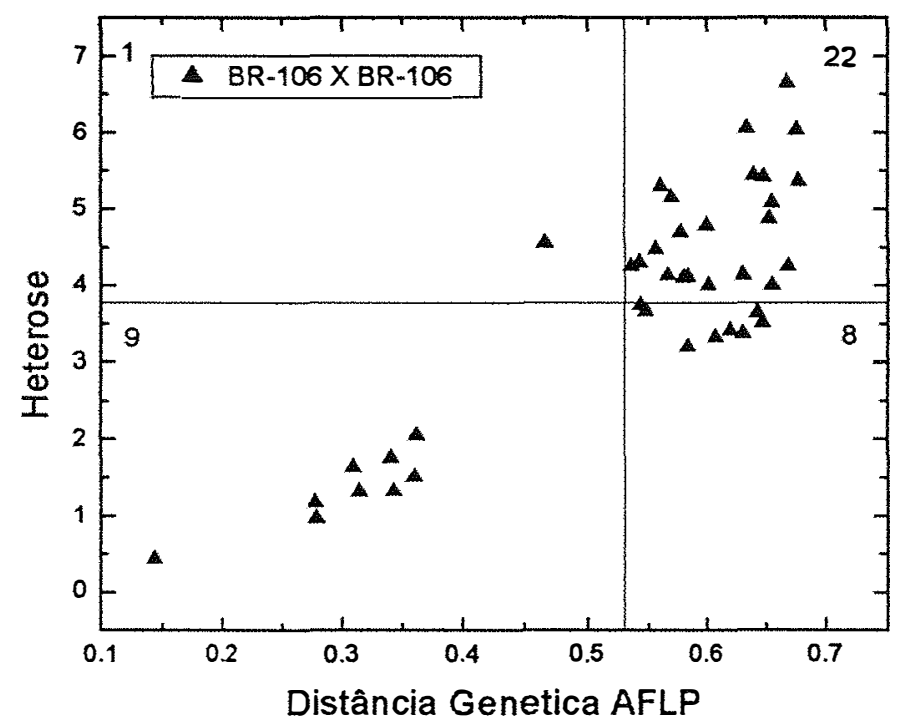

Figura 19 - Dispersão gráfica de 40 híbridos resultantes dos cruzamentos de linhagens dentro da população BR-106 com relação às distâncias genéticas obtidas com AFLP e heterose para produção de grãos.

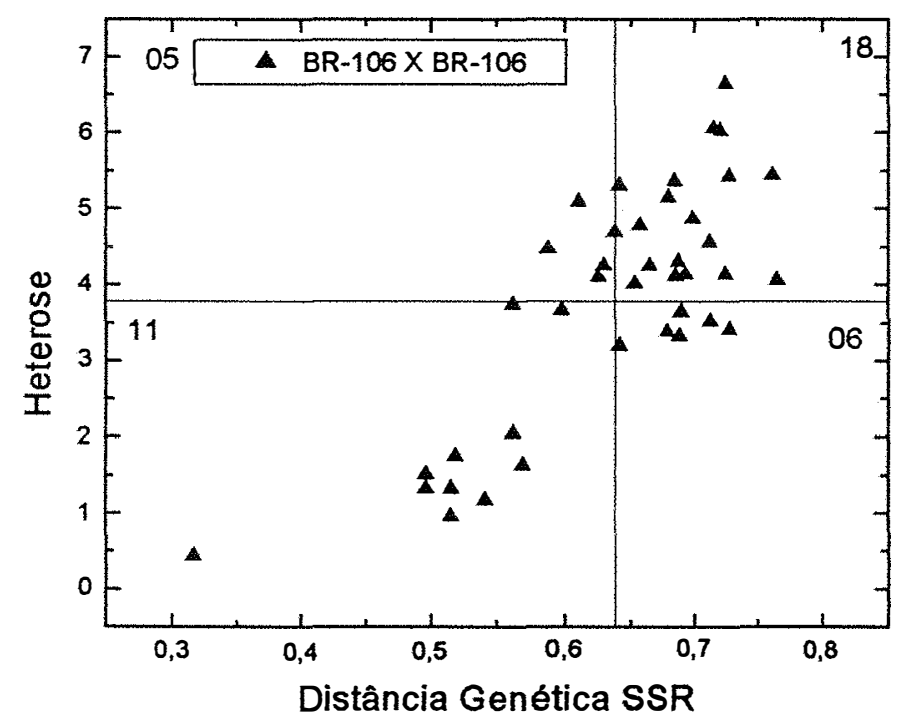

Figura 20 - Dispersão gráfica de 40 híbridos resultantes dos cruzamentos de linhagens dentro da população BR-106 com relação às distâncias genéticas obtidas com SSR e heterose para produção de grãos. 


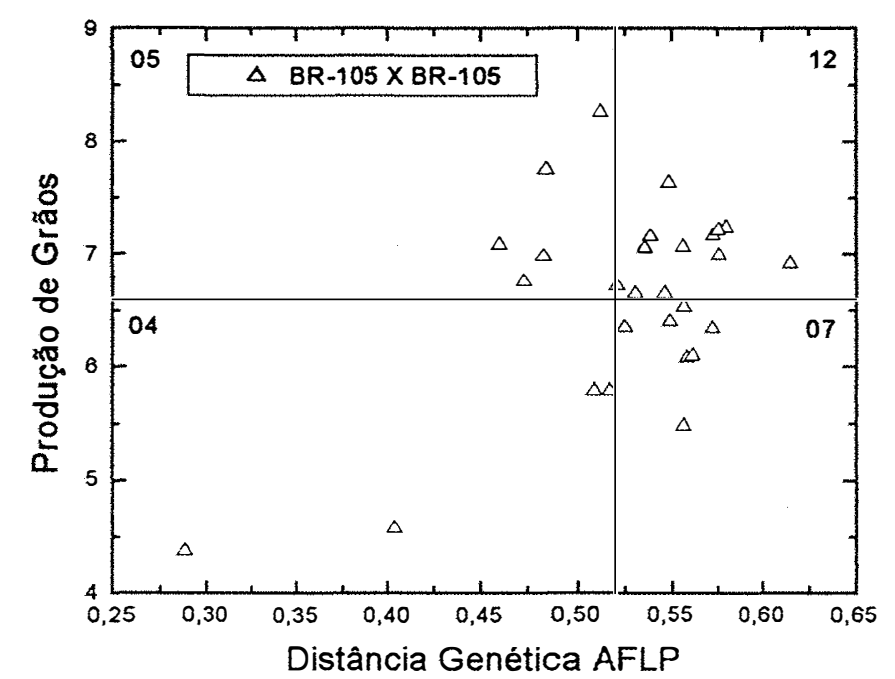

Figura 21 - Dispersão gráfica de 28 híbridos resultantes dos cruzamentos de linhagens dentro da população BR-105 com relação às distâncias genéticas obtidas com AFLP e produção de grãos.

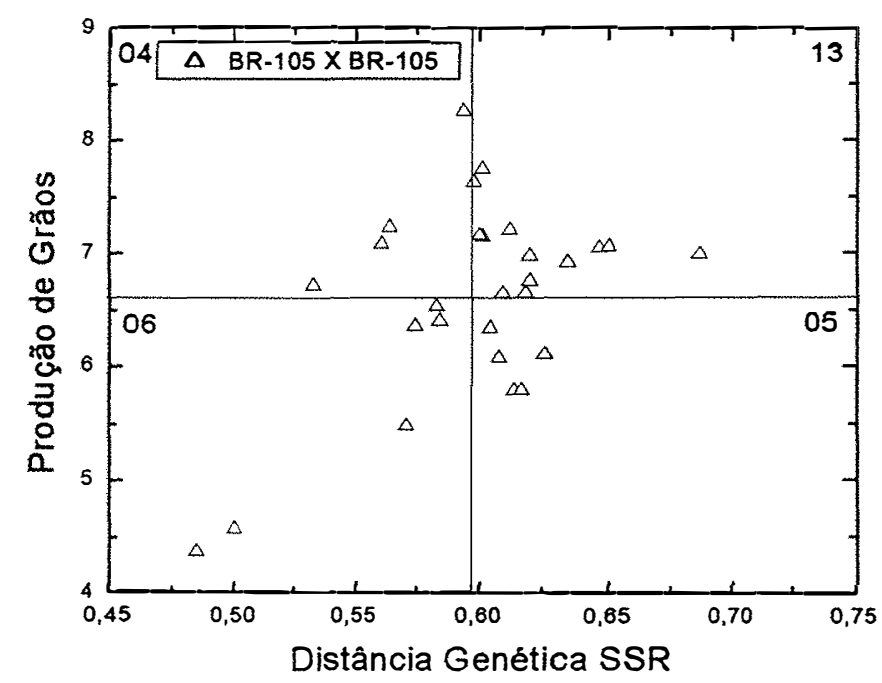

Figura 22 - Dispersão gráfica de 28 híbridos resultantes dos cruzamentos de linhagens dentro da população BR-105 com relação às distâncias genéticas obtidas com SSR e produção de grãos. 


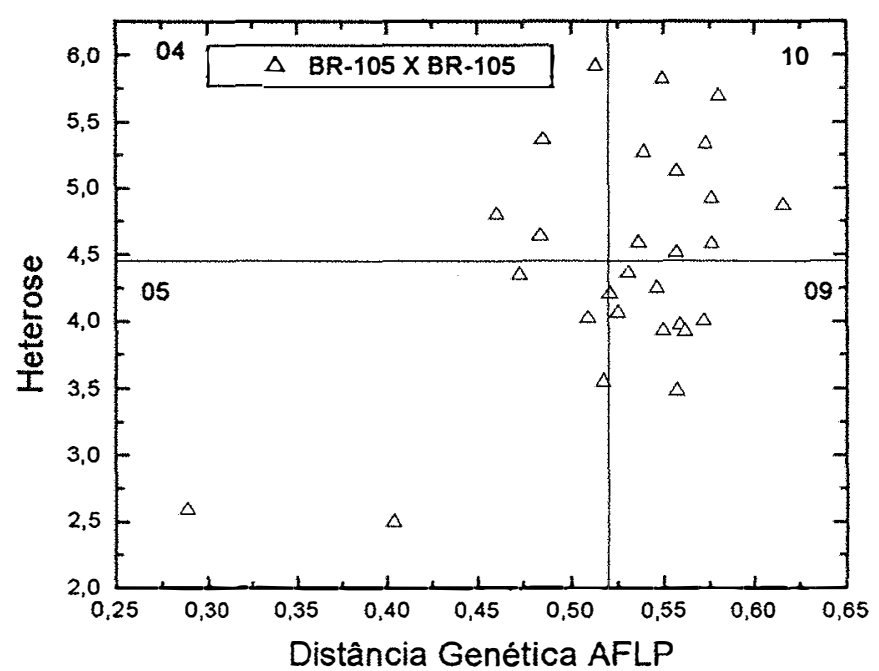

Figura 23 - Dispersão gráfica de 28 híbridos resultantes dos cruzamentos de linhagens dentro da população BR-105 com relação às distâncias genéticas obtidas com AFLP e heterose para produção de grãos.

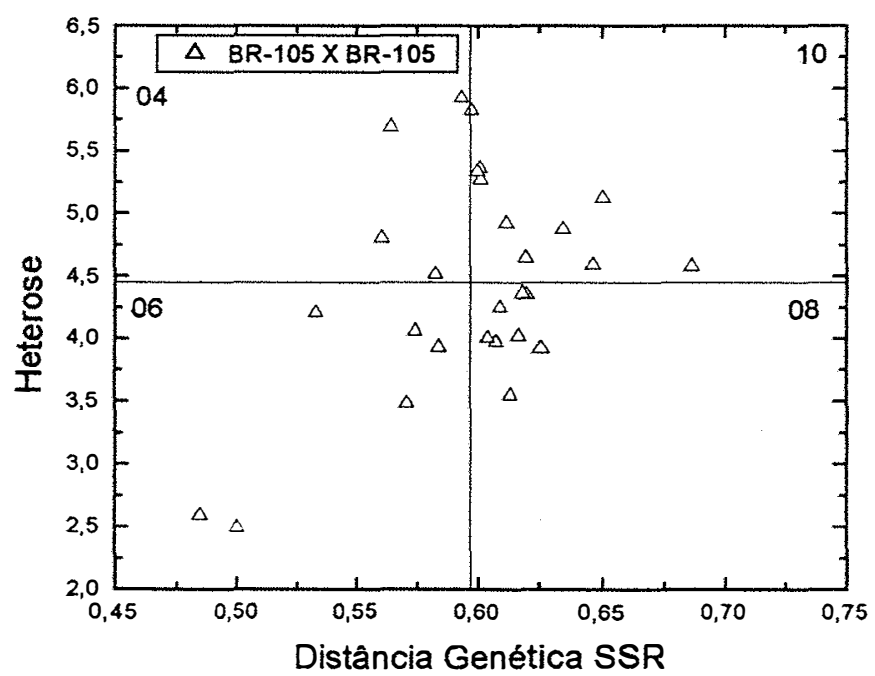

Figura 24 - Dispersão gráfica de 28 híbridos resultantes dos cruzamentos de linhagens dentro da população BR-105 com relação às distâncias genéticas obtidas com SSR e heterose para produção de grãos. 


\section{REFERÊNCIAS BIBLIOGRÁFICAS}

AJMONE MARSAN, P.; CASTIGLIONE, P.; FUSARI, F.; KUIPER, M.; MOTTO, M. Genetic diversity and its relationship to hybrid performance in maize as revealed by RFLP and AFLP markers. Theoretical and Applied Genetics, v. 96, p. $219-227,1998$.

AJMONE MARSAN, P.; MONFREFINI, G.; LUDWING, W. F.; MELCHINGER, A. E.; FRANCESCHINI, P.; PAGNOTTO, G.; MOTTO, M. In na elite cross of maize a major quantitative trait locus controls one-fourth of the genetic variation for grain yield. Theoretical and Applied Genetics, v. 90, p. 415424, 1995.

AMOS, B.; PEMBERTON, J. DNA fingerprinting in a non-human population. Current Opinion in Genetics and Development, v. 2, p. 857-860, 1992. ARCADE, A.; FAIVRE-RAMPANT, P.; LE GUERROUÉ, B.; PÂQUES, L.E.; PRAT, D. Heterozygosity and hybrid performance in Larch. Theoretical and Applied Genetics, v. 93, p. 1274-1281, 1996.

BARRET, B. A.; KIDWELL, K. K. AFLP-Based Genetic Diversity Assessment among wheat cultivars from the pacific northwest. Crop Science, v. 38, p. 1261-1271, 1998.

BELL, C.J.; ECKER, J. R. Assignment of 30 microsatellite loci to the linkage map of Arabidosis. Genomics, v. 19, p.137-144, 1994. 
BENCHIMOL, L. L.; SOUZA Jr., C. L.; GARCIA, A. A. F.; KONO, P. M. S.; MANGOLIN, C. A.; BARBOSA, A. M. M.; COELHO, A. S. G.; SOUZA, A. P. Genetic diversity in tropical maize inbred lines: heterotic group assignment and hybrid performance determined by RFLP markers. Plant Breeding, v.119, p. 491-496, 2000.

BERNARDO, R. Relationship between single-cross performance and molecular marker heterozygosity. Theoretical and Applied Genetics, v. 83, p. 628634, 1992.

BERNARDO, R. Prediction of maize single-Cross performance using RFLPs and information from related hybrids. Crop Science, v. 34, p. 20-25, 1994.

BERNARDO, R. RFLP markers and predicted testcross performance of maize sister inbreds. Theoretical and Applied Genetics, v. 95, p. 655-659, 1997

BEYERMANN, B.; NURNBERG, P.; WEIHE, A.; MEIXNER, M.; EPPLEN, J.T.; BORNER, T. Fingerprinting plant genomes with oligonucleotide probes specific for simple repetitive DNA sequences. Theoretical and Applied Genetics, v. 83, p.691-694, 1992.

BOPPENMAIER, J.; MELCHINGER, A. E.; BRUNKLAUS-JUNG, E.; GEIGER, H.H.; HERRMANN, R.G. Genetic diversity for RFLP in european maize inbreds: relation to performance of flint $x$ dent crosses for forage traits. Crop Science, v. 32, p. 895-902, 1992.

BOPPENMAIER, J.; MELCHINGER, A. E.; SEITZ, G., E.; GEIGER, H.H.; HERRMANN, R.G. Genetic diversity for RFLP in european maize inbreds: III. Performance of crosses: within versus between heterotic groups for grain traits. Plant Breeding, v. 111, p. 217-226, 1993.

BOTSTEIN, D.; WHITE, R.L.; SKOLNIC, M.; DAVIS, R.W. Constrution of a genetic linkage map in man using restriction fragment length polymorphisms. American Journal Human Genetics, v. 32, p.314-331, 1980.

BURR, B.; BURR, F.A.; THOMPSON, K.H.; ALBERTSON, M.C. Gene mapping whith recombinant inbreds in maize. Genetics, v. 118, p. 519-526, 1988. 
CHARCOSSET, A.; ESSIOUX, L. The effect of population structure on the relationship between heterosis and heterozygosity at marker loci. Theoretical and Applied Genetics, v. 89, p. 336-343, 1994.

CHARCOSSET, A.; LEFORT-BUSON, M.; GALLAIS, A. Relationship between heterosis and heterozygosity at marker loci: a theoretical computation. Theoretical and Applied Genetics, v. 81, p. 571-575, 1991.

CHERES, M. T.; MILLER, J. F.; CRANE, J. M.; KNAPP, S. J. Genetic distance as a predictor of heterosis and hybrid performance within and between heterotic groups in sunflower. Theoretical and Applied Genetics, v. 100, p. 889-894, 2000.

CHIN, E. C. L.; SENIOR, H.; SHU, H.; SMITH, J. S. C. Maize simple repetitive DNA sequences: abundance and allele variation. Genome, v. 39, p. 866$873,1996$.

CHO, Y. G.; BLAIR M. W.; PANAUD, O.; MCCOUCH, S. R. Cloning and mapping of variety-specific rice genomic sequences: amplified fragment length polymorphisms (AFLP) from silver-stained polyacryamide gels. Genome, v. 39, p.373-378, 1996.

CHOWDARI, K V.; VENKATACHALAM, S. R.; DAVIERWALA, A. P.; GUPTA, V. S.; RANJEKAR, P. K.; GOVILA, O. P. Hybrid performance and genetic distance as revealed by (GATA)4 microssatelite and RAPD markers in pearl millet. Theoretical and Applied Genetics, v. 97, $n^{\circ}$ 1/2, p.163-169, 1998.

COE Jr., E. H.; NEUFFER, M. G.; HOISINGTON, S. A. The genetics of corn. In: SPRAGUE, G.F.; DUDLEY, J.W. (Ed.) Corn and corn improvement. Wisconsin: Ames: lowa State University Press, 1988. cap. 3, p.81- 258.

CREGAN, P. B.; BHAGWAT, A. A.; AKKAYA, M. S.; RONGWEN, J. Microsatellite fingerprinting and mapping of soybean. Methods in Molecular Cell Biology, v. 5, p. 49-61, 1994. 
DALLAS, J.F. Detection of DNA "fingerprints" of cultivated rice by hibridization with a human minisatellite DNA probe. Proceedings of the National Academy of Sciences of the United States of America, v. 85, p. 68316835, 1988.

DAVID, L. S.; WALKER, M. D.; CLARCK, C. W.; PRAKASH, C. S.; DEAHL, K. Rapid Assessment of primer combinations and recovery of AFLP products using ethidium bromide staining. Plant Molecular Biology Repoter, v. 16, p. 41-47, 1998.

EAST, E.M. Heterosis. Genetics, v. 21, p.375-397, 1936.

FALCONER, D. S. Introduction to quantitative genetics, 2. ed., London: Longman, 1981, 438p..

FREI, O. M., STUBER, C. W., GOODMAN, M. M. Uses of allozymes as genetic markers for predicting performance in maize single-cross hybrids. Crop Science, v. 26, p. 37-42, 1986.

GEBHARDT, C.; RITTER, E.; DEBENER, T.; SCHACHTSCHABEL, U.; WALKEMEIER, B. RFLP analysis and linkage mapping in Solanum tuberosum. Theoretical and Applied Genetics, v. 78, p. 65-75, 1989.

GODSHALK, E. B.; LEE, M.; LAMKEY, K. R. Relationship of restriction fragment lenth polymorphisms to single-cross hybrid performance of maize. Theoretical and Applied Genetics, v. 80, p.273-280, 1990.

GONELLA, J. A.; PETERSON, P.A. Isozyme relatedness of inbred lines of maize and performance of their hybrids. Theoretical and Aplied Genetics, v. 85, p. $961-968,1978$.

GOODMAN, M. M.; STUBER, C. W. Races of maize. VI. Isozyme variation among races of maize in Bolivia. Maydica, v. 28, p.169-187, 1983.

GOWER, J. C. Some distant properties of latent root and vector methods used in multivariate analysis. Biometrika, v. 53, p. 325-338, 1996.

HALLAUER, A. R.; MIRANDA, J. B. Quantitative genetics in maize breeding, 2. ed. Ames: lowa State University Press, p. 468, 1988. 
HALLAUER, A R.; RUSSEL, W. A.; LAMKEY, K. R. Corn breding. n: SPRAGUE, G. F. AND DUDLEY, J. W. (Ed..) Corn and com improvement. Wisconsin: Ames: lowa State University Press, 1988. cap. 8, p. 469 -554. HEIDRICH-SOBRINHO, E.; CORDEIRO, A. R. Codominant isoenzymic alleles as markers of genetic diversity correlated with heterosis in maize (Zea mays). Theoretical and Aplied Genetics, v. 85, p. 197-199, 1975.

HELENTJARIS, T.; WEBER, D.; WRIGTH, S. Identification of the genomic locations of duplicated sequences in maize by anlysis of restriction fragment length polymorphisms. Genetics, v. 188, p. 353-363, 1988.

HUNTER, R. B.; KANNENBERG, L. W. Isozyme characterization of corn (Zea mays) inbreds and its relationship to single cross hybrid performance. Canadian Journal of Cytology, v. 13, p. 649-655, 1971.

JACCARD, P. Nouvelles recherches sur la distribuition florale. Bulletan de la Societe Vaudoise des Sciences Naturelles, v. 44, p. 223-270, 1908.

JEFFREY, A. J.; WILSON V.; THEIN S. L. Individual-specific " fingerprints" of human DNA. Nature, v.316, p. 76-79, 1985.

JONES, C. L.; EDWARDS, K. J.; CASTAGLIONE, S.; WINFIELD, M. O.; SALA, F.; VAN DE WIEL, C.; BREDEMEIJER, G.; VOSMAN, B.; MATTHES, M.; DALY, A.; BRETTSCHNEIDER, R.; BETTINI, P.; BUIATTI, M.; MAESTI, E.; MALCEVSCHI, A.; MARMIROLI, N.; AERT, R.; VOLCKAERT, G.; RUEDA, J.; LINACERO, R.; VAZQUEZ, A.; KARP, A. Reproducibility testing of RAPD, AFLP and SSR markers in plants by a network of European laboratories. Molecular Breeding, v. 3, p. 381-390, 1997.

JONES, D.F. Dominance of linked factors as a means of accounting for heterosis. Proceedings of the National Academy of Sciences of the United States of America , v. 85, p. 310 -317, 1917.

JUNG C.; PILLEN, K.; FRESE, L.; FAHR, S.; MELCHINGER, A. E. Phylogenetic relationship between cultivated and wild species of the genus Beta revealed by DNA "fingerprinting". Theoretical and Applied Genetics, v.86, p. 449-457, 1993. 
LAMKEY, K. R.; HALLAUER, A. R.; KAHLER, A. L. Allelic diferences at enzyme loci and hybrid performance in maize. The Journal of Heredity, v. 78, $p$. 231-234, 1987.

LANZA, L. L. B.; SOUZA Jr, C.L.; OTTOBONI, L. M. M.; VIEIRA, M. L. C.; SOUZA, A. P. Genetic distance of inbred lines and prediction of maize single-cross performance using RAPD markers. Theoretical and Applied Genetics, v. 94, p.1023-1030, 1997.

LAW, J. R.; DONINI, P.; KOEBNER, R. M. D.; REEVES, C. A.; COOKE, R. J. DNA profiling and plant variety registration. III: The statistical assessment of distinctness in wheat using amplified fragment length polymorphisms. Euphytica, v. 102, p. 335-342, 1998.

LEE, M.; GODSHALK, E. B.; LAMKEY, K. R.; WOODMAN, W. W. Association of restriction fragment length polymorphisms among maize inbreds with agronomic performance of their crosses. Crop Science, v. 29, p. 10671071, 1989.

LEVINSON, G.; GUTMAN, G. A. Slipped-strand mispairing: a major mechanism for DNA sequence evolution. Molecular Biology and Evolution, v. 4, p.203224, 1987.

LIFE TECHNOLOGIES. AFLP ${ }^{\text {TM }}$ analysis system I/AFLP starter primer kit, instruction manual.18p.

LIVINI, C.; AJMANE-MARSAN, P.; MELCHINGER, A. E.; MESSMER, M. M., MOTTO, M. Genetic diversity of maize inbred lines within and among heterotic groups by RFLPs. Theoretical and Applied Genetics, v. 84, p.1725, 1992.

MANTEL, N. A. The detection of disease clustering and a generalized regression approach. Cancer Research, v. 27, p. 209-220, 1967.

MAUGHAN, P. J.; SAGHAI MAROOF, M. A.; BUSS, G. R.; HUESTIS, G. M. Amplified fragment length polymorphism (AFLP) in soybean: species diversity, inheritance, and near-isogenic line analysis, Theoretical and Applied Genetics, v. 93, p. 392-401, 1996. 
MELCHINGER, A. E. Genetic diversity and heterosis. In: COORS, J. G.; PANDEY, S. (Ed.) Genetics and exploitation of heterosis in crops. Madison: ASA, CSSA, SSSA. 1999. p. 99-118.

MELCHINGER, A. E.; LEE, M.; LAMKEY, K. R.; WOODMAN, W. L. Genetic diversity for restriction fragment length polymorphisms: relation to estimated genetic effects in maize inbreds. Crop Science, v. 30, p. 1033-1040, 1990a. MELCHINGER, A. E.; LEE, M.; LAMKEY, K. R.; HALLAUER, A. R.; WOODMAN, W. L. Genetic diversity for restriction fragment length polymorphisms and heterosis for two diallel sets of maize inbreds. Theoretical and Applied Genetics, v. 80, p. 488-496, $1990 \mathrm{~b}$.

MELCHINGER, A. E.; MESSMER, M. M.; LEE, M.; WOODMAN, W. L.; LAMKEY, K. R. Diversity and relationships among U.S. maize inbreds revealed by restriction fragment length polymorphisms. Crop Science, v. 31, p. 669-678, 1991.

MELCHINGER, A. E.; BOPPENMAIER, J.; DHILLON, B. S.; POLLMER, W. G.; HERRMANN, R.G. II. Relation to performance of hybrids within versus between heterotic groups for forage traits. Theoretical and Applied Genetics, v.84, p. 672-681, 1992.

MESSMER, M. M.; MELCHINGER, A. E.; BOPPENMAIER, J.; BRUNKLAUSJUNG, E.; HERRMANN, R. G. Relationships among early european maize inbreds: I. Genetic diversity among flint and dent lines revealed by RFLPS. Crop Science, v. 32, p. 1301-1309, 1992.

MESSMER, M. M.; MELCHINGER, A. E.; LEE, M.; WOODMAN, W. L.; LEE, E. A.; LAMKEY, K. R. Genetic diversity among progenitors and elite lines from lowa Stiff Stalk Synthetic (BSSS) maize population: Comparison of allozyme and RFLP data. Theoretical and Applied Genetics, v.83, p. 97-107, 1991.

MILBOURNE, D.; MEYER, R.; BRADSHAU, J. E.; BAIRD, E.; BONAR, N.; PROVAN, J.; POWELL, W.; WAUGH. Comparison of PCR-based marker systems for the analysis of genetic relationships in cultivated potato. Molecular Breeding, v.3, p. 127-136. 1997. 
MILLE, M. TFPGA - Tool for population genetic analysis, version 1.3. Northern Arizona Univesity, 1997.

MOLL, R. H.; SALHUNA, W. S.; ROBINSON, H. F. Heterosis and genetic diversity in variety crosses of maize. Crop Science, v. 2, p. 197-198, 1962.

MOLL, R. H.; LONNQUIST, J. H.; FORTUNA, J. V.; JOHNSON, C. E. The relationship of heterosis and genetic divergence in maize. Genetics, v. 52, p. 139-144, 1965.

MOORE, G. S.; ABBO, W.; CHEUNG, T.; FOOTE, M. D.; GALE, R. M. D.; KOEBNER, A.; LEITCH, I.; LEITCH, T.; MONEY, P.; STANCOMBE, M.; YANO, M.; FLAVEL, R. B. Key features of cereal genome organization as revealed by the use of cytosine methylation-sensitive restriction endonucleases. Genomics, v. 15, p. 472-482, 1993.

MORGANTE, M. Genetic mapping and variability of seven soybean simple sequence repeat loci. Genome, v. 37, p. 763-769, 1994.

MORGANTE M.; OLIVIERI, A.M. PCR-amplified microsatellites as marker in plant genetics. The Plant Journal, v. 3, p.175-182, 1993.

MUM, R. H., DUDLEY, J. W. A classification of 148 U.S. maize inbreds. I. cluster analysis based on RFLPs. Crop Science, v. 34, p. 842-851, 1994.

NASPOLINI FILHO, V.; GAMA, E. E. G.; VIANNA, T. R.; MÔRO, J. R. General and specific combining ability for yield in a diallel cross among 18 maze populations (Zea mays L.). Revista Brasileira de Genética, v. 4, n. 4, p. 571-577, 1981.

NYBOM, H. Genetic variation in ornamental apple trees and their seedlings (Malus rosaceae) revealed by DNA "fingerprinting" with M13 repeat probe. Hereditas, v. 133, p. 17-28, 1990.

OGLIARI, J. B. Identificação e localização de um gene de resistência de milho A Exserohilum turcicum (Pass.) Leonard \& Suggs através do uso de marcadores microssatélites. Piracicaba, 1999. 115p, Tese (Doutorado) Escola Superior de Agricultura "Luís de Queiroz", Universidade de São Paulo. 
PATERNIANI, E.; LONNQUIST, J. H. Heterosis in interracial crosses of corn (Zea mays L.). Crop Science, v.3, p.504-507, 1963.

PEJIC, I.; AJMONE MARSAN, P.; MORGANTE, M.; KOZUMPLICK, V.; CASTIGLIONI, P.; TARAMINO, G.; MOTTO, M. Comparative analysis of genetic similarity among maize inbred lines detected by RFLPs, RAPDs, SSRs, and AFLPs. Theoretical and Applied Genetics, v. 97, p. 1248-1255, 1998.

PINTO, R. M C. Comparações de marcadores moleculares e cruzamentos dialélicos na alocação de linhagens de milho em grupos heteróticos. Piracicaba, 2000. 147p. Tese (Doutorado) - Escola Superior de Agricultura Luís de Queiroz", Universidade de São Paulo.

POWELL, W.; MORGANTE, M.; ANDRÉ, C.; RAFALSKI, A. The comparison of RFLP, RAPD, AFLP and SSR (microssatelite) markers for germoplasm analysis. Molecular Breeding, v. 2, p. 225-238, 1996.

PRICE, S. C.; KAHLER, A L.; HALLAUER, A .R.; CHARMLEY, P.; GIEGEL, P. Relationship at enzyme loci in single-cross hybrids of maize. The Journal of Heredity, v. 77, p. 341-344, 1986.

RAMASH, V. K; ZENG, X.; BENNETZEN, J. L.; ZEHR, B. E. Assessment of genetic diversity in dent and popcorn (Zea mays L.) inbred lines using intersimple sequence repeat (ISSR) amplification. Molecular Breeding, v.1, p. 365-373, 1995.

ROGSTAD, S.H.; PATTON, J.C.; SCHAAL, B. A. M13 repeat probe detects DNA minisatellite-like sequences in gymnosperms and angiosperms. Proceedings of the National Academy of Sciences of the United States of America, v. 85, p. 9176-9178, 1988.

ROHLF, F. J. NTSYS-pc numerical taxonomy and multivariate analysis system, version 2.0. New York: Exeter Publications, p. 103, 1997.

RUSSEL, J.; FULLER, J.; YOUNG, G.; THOMAS, B.; TARAMINO, G.; MACAULAY, M.; WAUGH, R.; POWEEL, W. Discriminating between barley genotypes using microsatellite markers. Genome, v. 40, p. 442-450, 1997 
SAGHAI-MAROOF, M. A.; SOLIMAN, K. M.; JORGENSEN, R. A.; ALLARD, R.

W. Ribosomal DNA spacer length polymorphisms in barley: Mendelian inheritance, chromosomal location, and population dynamics. Proceedings of the National Academy of Sciences of the United States of America, v. 83, p. 1757-1761, 1984.

SENIOR, M. L.; HEUN, M. Mapping maize microsatellites and polymerase chain reaction confirmation of the targeted repeats using a CT primer. Genome, v.36, p. 884-889, 1993.

SENIOR, M. L.; CHIN, E. C. L.; LEE, M.; SMITH, J. S. C.; STUBER, C. W. Simple sequence repeat markers developed from maize sequences found in the Genbank database: Map construction. Crop Science, v.36, p. 16761683, 1996.

SHULL, G. H. A pure line method of corn breeding. American Breeders Association Report, v. 5, p. 51-59, 1909.

SHULL, G.H. Beginnings of the heterosis concept. In: GOWEN J. W.(Ed.) Heterosis. Ames: lowa State College Press, 1952, p. 14-48.

SMITH, J. S. C.; SMITH, O. S.; BROWEN, S. L.; TENBORG, R. A.; WALL, S. J. Similarities among a group of elite maize inbreds as mesured by pedigree, F1 grain yield, grain yield, heterosis and RFLPs. Theoretical and Applied Genetics, v. 80, p. 833-840, 1990.

SMITH, J. S. C.; CHIN, E. C. L.; SHU, H.; SMITH, O. S.; WALL, S. J.; SENIOR, M. L.; MITCHELL, S. E.; KRESOVICH, S.; ZIEGLE, J. An evaluation of the utility of SSR loci as molecular markers in maize (Zea mays L.): comparisons with data from RFLPs and pedigree. Theoretical and Applied Genetics, v. 95, p.163-173, 1997.

SMITH, S.; LUK, S.; SOBRAL, B.; MUHAWISH, S.; PELEMAN, J.; ZABEAU, M. Associations among inbred lines of maize using RFLP and amplification technologies (AFLP and AP-PCR), and correlations with pedigree, F1 yield and heterosis. Maize Genetics Newsletters, v. 68, p. 45, 1994. 
SOUZA Jr,, C. L.; SANTOS, M. X.; MAGNAVACA, R.; GAMA, E. E. G. Estimativas de parâmetros genéticos na interpopulaçảo de milho BR-105 e BR-106 e suas implicaçōes no melhoramento. Pesquisa Agropecuária Brasileira, v.28, n. 4, p. $473-479,1993$.

TANKSLEY, S. D.; YOUNG, N. D.; PATERSON, A. H.; BONJERBALE, M. W. RFLP mapping in plant breeding: New tools for na old science. Bio/Technology, v. 7, p. 257-264, 1989.

TARAMINO, G.; TINGEY, S. Simple sequence repeats for germplasm analysis and mapping in maize. Genome, v.39, p.2277-287, 1996.

TIVANG, J.G.; NIENHUIS, J.; SMITH, O. S. Estimation of sampling variance of molecular marker data using bootstrap procedure. Theoretical and Applied Genetics, v. 89, p.259-264, 1994.

TZURI, G.; HILLEL, J.; LAVI, U.; HARBEFELD, A.; VAINSTEIN, A. DNA fingerprintin analysis of ornamental plants. Plant Science, v. 76, p. 91-97, 1991.

VOS, P.; ROGERS, R.; BLEEKER M.; REIJANS, M.; VAN DE LEE, T.; HORNES, M.; FRIJTERS, A.; POT, J.; PELEMAN, J.; KUIPE, M.; ZABEAU, M. AFLP: A new tecnique for DNA fingerprinting. Nucleic Acids research, v. 23, p. 4407-4414, 1995.

WILLIAMS, J. G. K.; KUBELIK, A. R.; LIVAK, K. J.; RAFALSKI, J. A.; TINGEY, S. V. DNA polimorfisms amplified by arbitrary primers are useful as genetic markers. Nucleic Acids Research, v. 18, p. 7213-7218, 1990.

WU, M. Genetic diversity and its relationship to hybrid performance and heterosis in maize as revealed by AFLPs and RAPDs. Maize Genetics Cooperation Newsletter, n. 74, p. 62-63, 2000.

ZHOU, Z.; GUSTAFSON, J.P. Genetic variation detected by DNA fingerprinting with a rice minisatellite probe in Oryza sativa. Theoretical and Applied Genetics, v. 91, p.481-488, 1995. 
ZHU, J.; GALE, M. D.; QUARRIE, S.; JACKSON, M. I.; BRYAN, G. J. AFLP markers for the study of rice biodiversity. Theoretical and Applied Genetics, v. 96, p. 602-611,1998. 